Supporting Information for

\title{
Mechanism of O-Atom Transfer from Nitrite: Nitric Oxide Release at Copper(II)
}

Molly Stauffer, Zeinab Sakhaei, Christine Greene, Pokhraj Ghosh, Jeffery A. Bertke, and Timothy H. Warren*

Department of Chemistry, Georgetown University, Box 571227, Washington, D. C., 200571227, United States.

*Corresponding author email: thw@georgetown.edu

\section{Table of Contents}

1. Instrumentation and Physical Methods

2. Materials

S3

3. Synthesis and Characterization of $\left[\mathrm{Me}_{2} \mathrm{NN}_{\mathrm{F} 6}\right] \mathrm{Cu}\left(\kappa^{2}-\mathrm{O}_{2} \mathrm{~N}\right)$ (2)

S4

4. Synthesis and Characterization of $\left[\mathrm{Cl}_{2} \mathrm{NN}\right] \mathrm{Cu}\left(\kappa^{2}-\mathrm{O}_{2} \mathrm{~N}\right)(3)$

S5

5. Synthesis and Characterization of $\left[\mathrm{Me}_{2} \mathrm{NN}\right] \mathrm{Cu}\left(\kappa^{2}-\mathrm{O}_{2} \mathrm{~N}\right)(4)$

S6

6. Synthesis and Characterization of $\left[\mathrm{Cl}_{2} \mathrm{NN}_{\mathrm{F} 6}\right] \mathrm{Cu}\left(\mathrm{PPh}_{3}\right)(\mathbf{5})$

S7

7. Synthesis and Characterization of $\left[\mathrm{Cl}_{2} \mathrm{NN}_{\mathrm{F} 6}\right] \mathrm{Cu}\left(\mathrm{P}\left(\mathrm{Ar}^{\mathrm{CF} 3}\right)_{3}\right)(\mathbf{6})$

8. Electrochemistry

9. Reaction of $\mathbf{1}$ with $\mathrm{P}\left(\mathrm{Ar}^{\mathrm{CF} 3}\right)_{3}$

10. NO Generation with 1 and $\mathrm{PPh}_{3}$

11. NO Generation with $\mathbf{1}$ and $\mathrm{P}\left(\mathrm{Ar}^{\mathrm{CF} 3}\right)_{3}$

12. Kinetic Analysis

13. Eyring Analysis

14. Hammett Analysis

15. Crystallographic Details

16. Computational Study

17. References for Computational Section 


\section{Instrumentation and Physical Methods.}

Preparation and handling of air-sensitive chemicals were done under dry nitrogen atmosphere by utilizing MBraun gloveboxes and/or standard Schlenk techniques. ${ }^{1} \mathrm{H},{ }^{13} \mathrm{C}\left\{{ }^{1} \mathrm{H}\right\}$, and ${ }^{19} \mathrm{~F}$ NMR spectra were obtained on a Varian $400 \mathrm{MHz}$ spectrometer at room temperature (RT) unless otherwise noted. ${ }^{31} \mathrm{P}$ NMR spectra were recorded on a Varian $300 \mathrm{MHz}$ spectrometer at RT. ${ }^{1} \mathrm{H}$ and ${ }^{13} \mathrm{C}$ chemical shifts were reported as $\delta$ values downfield from the internal standard tetramethylsilane. ${ }^{19} \mathrm{~F}$ NMR spectra were recorded at $282.344 \mathrm{MHz}$ using a reference of $\mathrm{C}_{6} \mathrm{H}_{5} \mathrm{CF}_{3}$ $(\delta=-63.72 \mathrm{ppm}) .{ }^{31} \mathrm{P}$ chemical shifts were referenced relative to an external standard of bis(4fluorophenyl)phenylphosphine oxide $(\delta=23.91 \mathrm{ppm})$. Elemental analyses were performed on a Perkin-Elmer PE2400 microanalyzer at Georgetown University. UV-vis spectra were recorded either on a Cary 50 dual beam or Agilent 8454 Diode Array spectrometer equipped with a stirrer and a Unisoku USP-203 cryostat for variable temperature $\left(-70{ }^{\circ} \mathrm{C}\right.$ to $\left.45^{\circ} \mathrm{C}\right)$ experiments. The molar extinction coefficients of different isolated complexes were determined from the Beer's law plot (absorbance $v s$ concentration) with at least four different concentrations.

Cyclic voltammetry measurements were carried out at RT under dry nitrogen atmosphere using BASi Epsilon potentiostat. A three-electrode system was used and consisted of a glassy carbon working electrode, high surface area platinum coil counter electrode, and a BASI nonaqueous reference electrode (MF-2062) containing a silver wire immersed in $0.01 \mathrm{M} \mathrm{AgNO}_{3}$ in THF.

EPR measurements were performed in air-tight quartz tubes. EPR spectra were recorded on a JEOL continuous wave spectrometer JES-FA200 equipped with an X-band Gunn oscillator bridge, a cylindrical mode cavity, and a liquid nitrogen cryostat. EPR measurements were performed in sealed quartz tubes and the simulation of EPR spectra were carried out using the program QCMP 136 by Prof. Dr. Frank Neese from the Quantum Chemistry Program Exchange as described by Neese et al. in J. Am. Chem. Soc. 1996, 118, 8692-8699. 


\section{Materials.}

All chemicals were purchased from regular vendors (e.g. Sigma-Aldrich, Acros Organics, Strem Chemicals, TCI, Combi-Blocks) and used without further purification unless otherwise mentioned. Molecular sieves (4A, 4-8 mesh beads) were obtained from Fisher Scientific and activated in vacuo at $180{ }^{\circ} \mathrm{C}$ for $24 \mathrm{~h}$. Extra dry solvents $(\geq 99.5 \%)$ with Acroseal ${ }^{\circledR}$ and deuterated solvents were purchased from Acros Organics and Cambridge Isotope Laboratories, respectively. Both anhydrous and deuterated solvents were sparged with nitrogen and stored over activated molecular sieve under nitrogen atmosphere.

$\left[\mathrm{Cl}_{2} \mathrm{NN} \mathrm{F}_{6}\right] \mathrm{Cu}\left(\kappa^{2}-\mathrm{O}_{2} \mathrm{~N}\right)(\mathbf{1}),{ }^{1}\left\{\left[\mathrm{Me}_{2} \mathrm{NN}_{\mathrm{F} 6}\right] \mathrm{Cu}\right\}_{2},{ }^{2}\left\{\left[\mathrm{Cl}_{2} \mathrm{NN}\right] \mathrm{Cu}\right\}_{2}$ (benzene) ${ }^{3}$ and $\left\{\left[\mathrm{Me}_{2} \mathrm{NN}\right] \mathrm{Cu}\right\}_{2},{ }^{4}$ were synthesized according to previously published procedures. 


\section{Synthesis and Characterization of $\left[\mathrm{Me}_{2} \mathrm{NN}_{\mathrm{F} 6}\right] \mathrm{Cu}\left(\kappa^{2}-\mathrm{O} 2 \mathrm{~N}\right)(2)$.}

A mixture of $\left\{\left[\mathrm{Me}_{2} \mathrm{NN}_{\mathrm{F} 6}\right] \mathrm{Cu}\right\}_{2}(0.931 \mathrm{~g}, 0.976 \mathrm{mmol})$ and 2.1 equiv. $\mathrm{AgNO}_{2}(0.310 \mathrm{~g}, 2.010$ mmol) in anhydrous fluorobenzene $(\sim 7 \mathrm{~mL})$ was stirred at room temperature for $6 \mathrm{~h}$. The resultant dark green reaction mixture was filtered and crystallized from a layered mixture of fluorobenzene/pentane at $-40{ }^{\circ} \mathrm{C}$, resulting in $0.365 \mathrm{~g}$ of crystals for a $36 \%$ yield. Elemental analysis: calculated for $\mathrm{C}_{21} \mathrm{H}_{19} \mathrm{~F}_{6} \mathrm{~N}_{3} \mathrm{O}_{2} \mathrm{Cu}$ : C, 48.23; H, 3.66; N, 8.04. Found: $\mathrm{C}, 48.39 ; \mathrm{H}, 3.62$; $\mathrm{N}$, 7.94. UV-vis (benzene, $\left.25^{\circ} \mathrm{C}\right): \lambda_{\max }=598 \mathrm{~nm}\left(\varepsilon=502 \mathrm{M}^{-1} \mathrm{~cm}^{-1}\right)$.
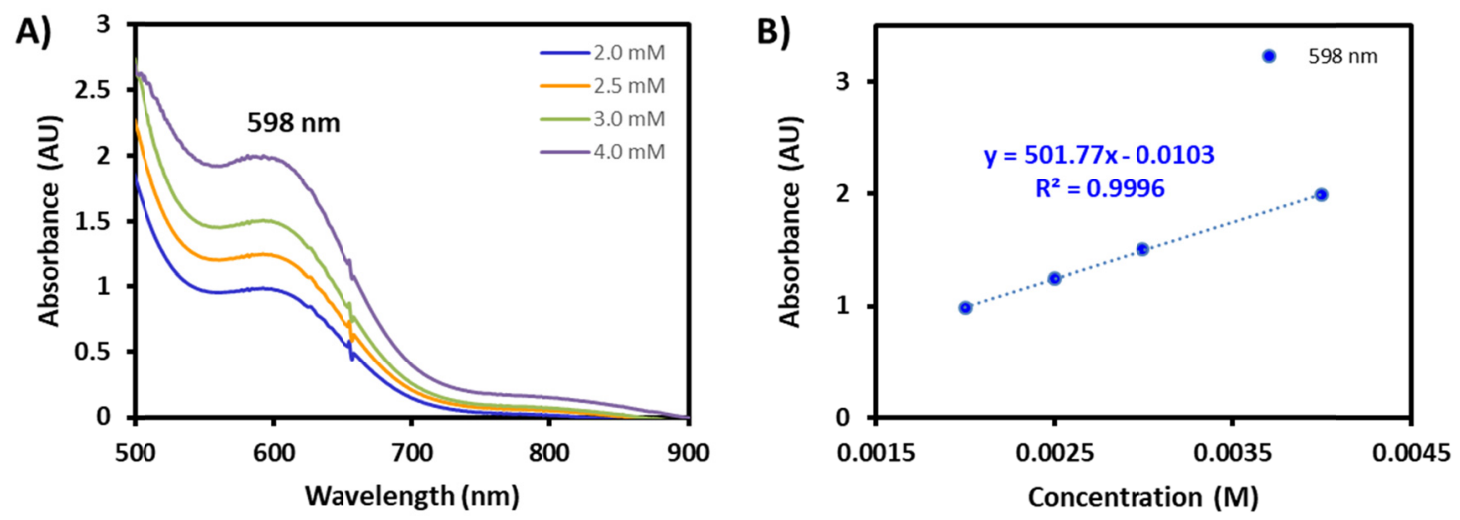

Figure S1. A) UV-vis spectra of 2 in benzene at $25{ }^{\circ} \mathrm{C}$ at different concentrations. B) Beer's law plot for 2 depicts $\lambda_{\max } / \mathrm{nm}\left(\varepsilon / \mathrm{M}^{-1} \mathrm{~cm}^{-1}\right)=598(502)$.

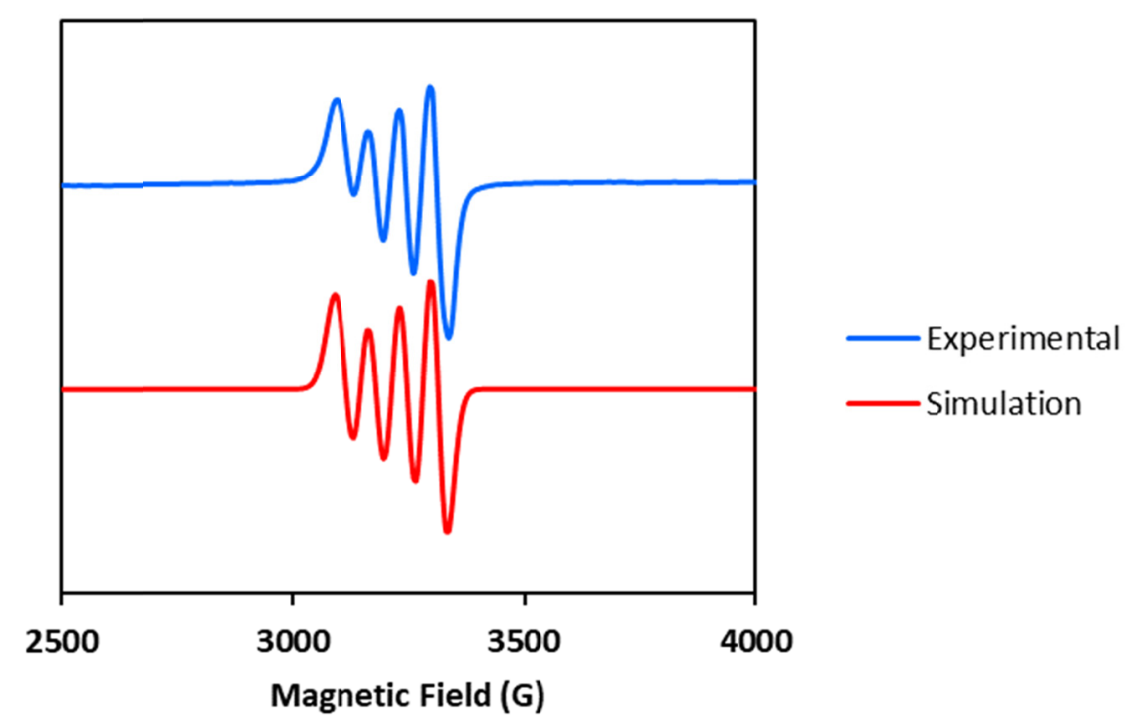

Figure S2. Isotropic X-band EPR spectrum and simulation for $\left[\mathrm{Me}_{2} \mathrm{NN}_{\mathrm{F} 6}\right] \mathrm{Cu}\left(\kappa^{2}-\mathrm{O}_{2} \mathrm{~N}\right)$ (2) $(2.0$ $\mathrm{mM}$ in benzene at $293 \mathrm{~K}$ ). Frequency $=9.412571 \mathrm{GHz}$. Simulation was performed using $1 \mathrm{Cu}$ model: $g_{\text {iso }}=2.088, A_{\text {iso }}\left({ }^{63 / 65} \mathrm{Cu}\right)=196 \mathrm{MHz}$. 


\section{Synthesis and Characterization of $\left[\mathrm{Cl}_{2} \mathrm{NN}\right] \mathrm{Cu}\left(\kappa^{2}-\mathrm{O}_{2} \mathrm{~N}\right)(3)$.}

A mixture of $\left\{\left[\mathrm{Cl}_{2} \mathrm{NN}\right] \mathrm{Cu}\right\}_{2}$ (m-benzene) $(0.578 \mathrm{~g}, 0.590 \mathrm{mmol})$ and 3.5 equiv. $\mathrm{AgNO}_{2}(0.316 \mathrm{~g}$, $2.05 \mathrm{mmol})$ in anhydrous fluorobenzene $(10 \mathrm{~mL})$ was stirred at room temperature for $3 \mathrm{~h}$. The resultant dark green reaction mixture was filtered and crystallized at $-40{ }^{\circ} \mathrm{C}$ resulting in $0.206 \mathrm{~g}$ of crystals for a $35 \%$ yield. Anal. Calcd for $\mathrm{C}_{17} \mathrm{H}_{13} \mathrm{Cl}_{4} \mathrm{CuN}_{3} \mathrm{O}_{2}$ : C, 41.11; H, 2.64; N, 8.46. Found: C, 41.16; H, 2.72; N, 8.39. UV-vis (toluene, $\left.25^{\circ} \mathrm{C}\right): \lambda_{\max }=595 \mathrm{~nm}\left(\varepsilon=212 \mathrm{M}^{-1} \mathrm{~cm}^{-1}\right)$.

A)

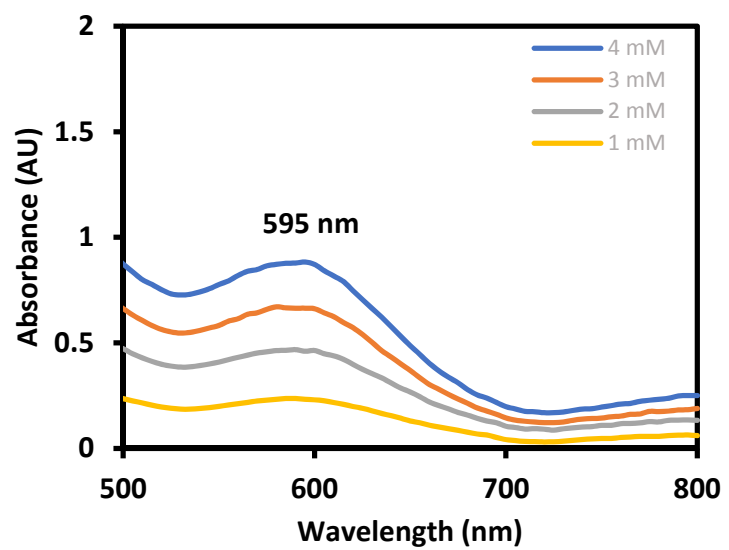

B)

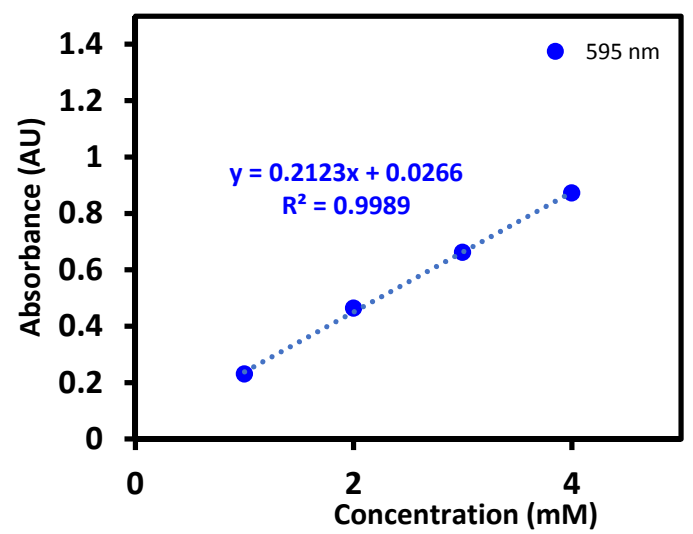

Figure S3. A) UV-vis spectra of 3 in toluene at $25^{\circ} \mathrm{C}$ at different concentrations. B) Beer's law plot for 3 depicts $\lambda_{\max } / \mathrm{nm}\left(\varepsilon / \mathrm{M}^{-1} \mathrm{~cm}^{-1}\right)=595(212)$.

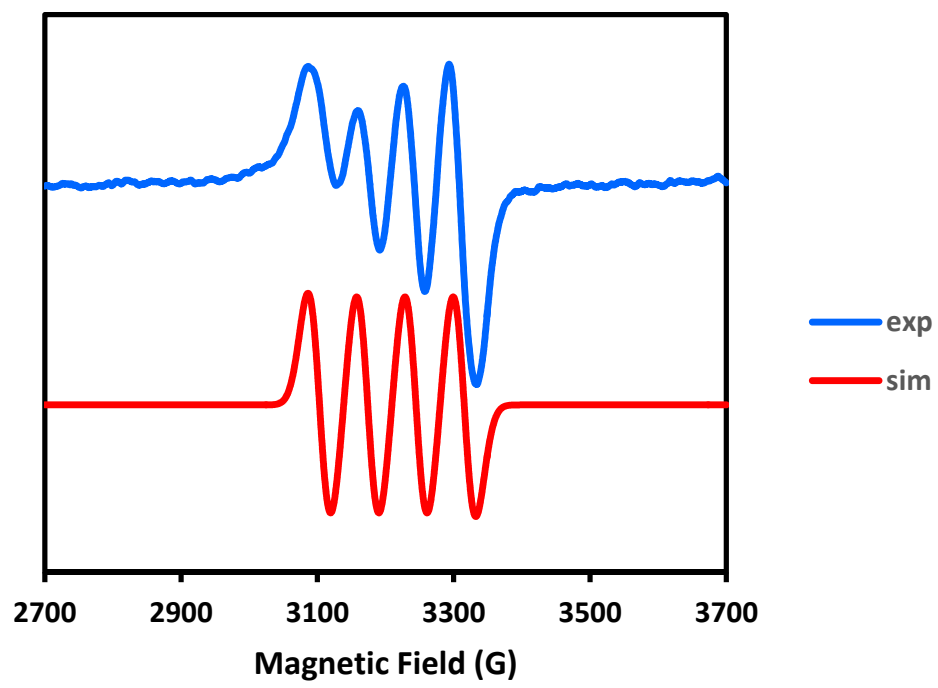

Figure S4. Isotropic X-band EPR spectrum and simulation for $\left[\mathrm{Cl}_{2} \mathrm{NN}\right] \mathrm{Cu}\left(\kappa^{2}-\mathrm{O}_{2} \mathrm{~N}\right)$ (3) $(0.2 \mathrm{mM}$ in toluene at $298 \mathrm{~K})$. Frequency $=9.433876 \mathrm{GHz}$. Simulation was performed using 1Cu model: $g_{\text {iso }}=2.100, A_{\text {iso }}\left({ }^{63 / 65} \mathrm{Cu}\right)=208 \mathrm{MHz}$. 


\section{Synthesis and Characterization of $\left[\mathrm{Me}_{2} \mathrm{NN}\right] \mathrm{Cu}\left(\kappa^{2}-\mathrm{O}_{2} \mathrm{~N}\right)(4)$.}

A mixture of $\left\{\left[\mathrm{Me}_{2} \mathrm{NN}\right] \mathrm{Cu}\right\}_{2}(0.217 \mathrm{~g}, 0.485 \mathrm{mmol})$ and 1.2 equiv. $\mathrm{AgNO}_{2}(0.090 \mathrm{~g}, 0.582$ $\mathrm{mmol})$ in anhydrous fluorobenzene $(5 \mathrm{~mL})$ was stirred at room temperature for $1 \mathrm{~h}$. The resultant dark green reaction mixture was filtered, evaporated under reduced pressure to afford a green powder, dissolved in pentane and crystallized at $-40{ }^{\circ} \mathrm{C}$ resulting in $0.113 \mathrm{~g}$ of crystals for a $56 \%$ yield. Anal. Calcd for $\mathrm{C}_{21} \mathrm{H}_{25} \mathrm{CuN}_{3} \mathrm{O}_{2}$ : C, 60.78; H, 6.07; N, 10.13. Found: $\mathrm{C}, 61.16 ; \mathrm{H}, 6.19 ; \mathrm{N}$, 9.79. UV-vis (toluene, $\left.25^{\circ} \mathrm{C}\right): \lambda_{\max }=600 \mathrm{~nm}\left(\varepsilon=294 \mathrm{M}^{-1} \mathrm{~cm}^{-1}\right)$.
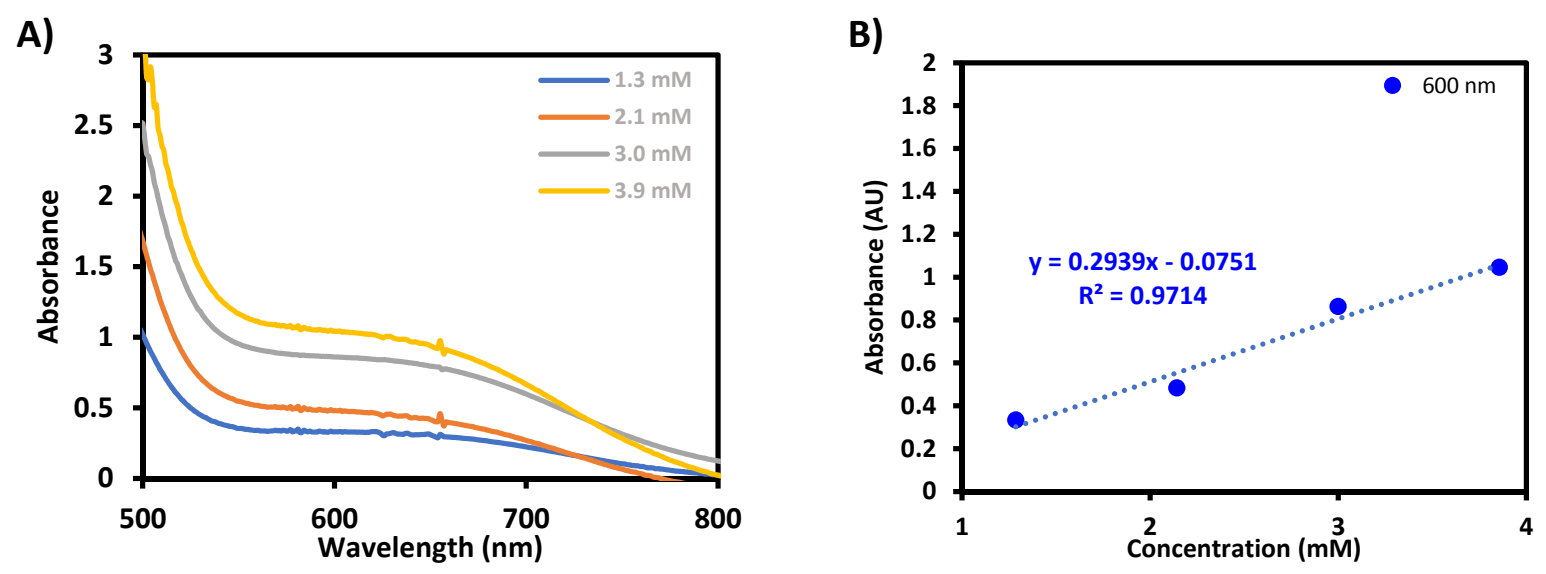

Figure S5. A) UV-vis spectra of 4 in toluene at $25^{\circ} \mathrm{C}$ at different concentrations. B) Beer's law plot for 4 depicts $\lambda_{\max } / \mathrm{nm}\left(\varepsilon / \mathrm{M}^{-1} \mathrm{~cm}^{-1}\right)=600$ (294).

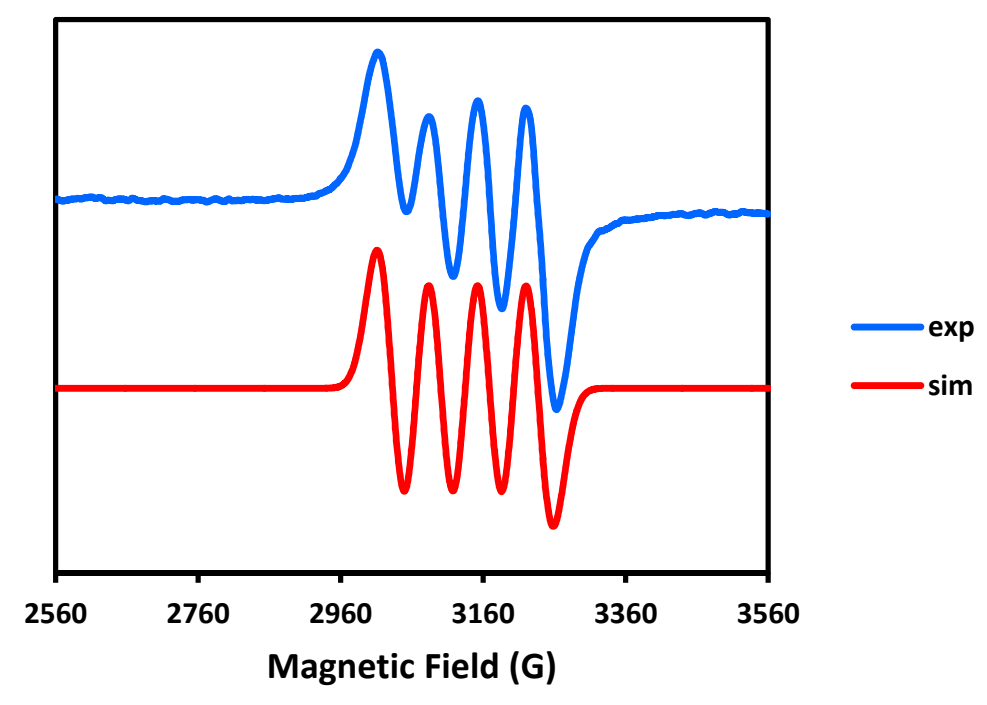

Figure S6. Isotropic X-band EPR spectrum for $\left[\mathrm{Me}_{2} \mathrm{NN}\right] \mathrm{Cu}\left(\kappa^{2}-\mathrm{O}_{2} \mathrm{~N}\right)(4)(4.0 \mathrm{mM}$ in pentane at $298 \mathrm{~K})$. Frequency $=9.1843980 \mathrm{GHz}$. .Simulation was performed using $1 \mathrm{Cu}$ model: $g_{\text {iso }}=2.093, A_{\text {iso }}\left({ }^{63 / 65} \mathrm{Cu}\right)=200 \mathrm{MHz}$. 


\section{Synthesis and Characterization of $\left[\mathrm{Cl}_{2} \mathrm{NN}_{\mathrm{F} 6}\right] \mathrm{Cu}\left(\mathrm{PPh}_{3}\right)$ (5).}

A mixture of $\left\{\left[\mathrm{Cl}_{2} \mathrm{NN}_{\mathrm{F} 6}\right] \mathrm{Cu}\right\}_{2}$ (benzene) $(0.140 \mathrm{~g}, 0.117 \mathrm{mmol})$ and 2.1 equiv. $\mathrm{PPh}_{3}(0.066 \mathrm{~g}$, $0.251 \mathrm{mmol})$ in anhydrous fluorobenzene $(5 \mathrm{~mL})$ was stirred at room temperature overnight. The resultant orange reaction mixture was filtered and crystallized with a layer of pentane at $-40{ }^{\circ} \mathrm{C}$ for $0.149 \mathrm{~g}$ of crystals for a 78\% yield. ${ }^{1} \mathrm{H}$ NMR $\left(400 \mathrm{MHz}, 298 \mathrm{~K}, \mathrm{C}_{6} \mathrm{D}_{6}\right): \delta 6.96(\mathrm{~m}, 9 \mathrm{H}, p$-Ar$H, m-A r-H), 6.83$ (t, 6H, o-Ar- $H$ ), 6.69 (d, 4H, $m-A r-H), 6.40$ (s, 1H, backbone-CH), 6.15 (t, 2H, $p$-Ar- $H .{ }^{19} \mathrm{~F}$ NMR $\left(376 \mathrm{MHz}, \mathrm{C}_{6} \mathrm{D}_{6}\right): \delta-64.54(\mathrm{~s},-\mathrm{C} F 3) .{ }^{13} \mathrm{C}\left\{{ }^{1} \mathrm{H}\right\}$ NMR $\left(100 \mathrm{MHz}, \mathrm{C}_{6} \mathrm{D}_{6}\right): \delta$ $145.86,133.57,133.42,132.23,131.84,130.00,129.98,129.82,128.86,128.76,124.90 .{ }^{31} \mathrm{P}$ NMR (300 MHz, $\left.\mathrm{C}_{6} \mathrm{D}_{6}\right): \delta$ 3.70. Anal. Calcd for $\mathrm{C}_{21} \mathrm{H}_{25} \mathrm{Cl}_{4} \mathrm{CuF}_{6} \mathrm{~N}_{2} \mathrm{P}: \mathrm{C}, 51.21 ; \mathrm{H}, 2.70 ; \mathrm{N}, 3.41$. Found: C, $51.41 ; \mathrm{H}, 2.83 ; \mathrm{N}, 3.39$.

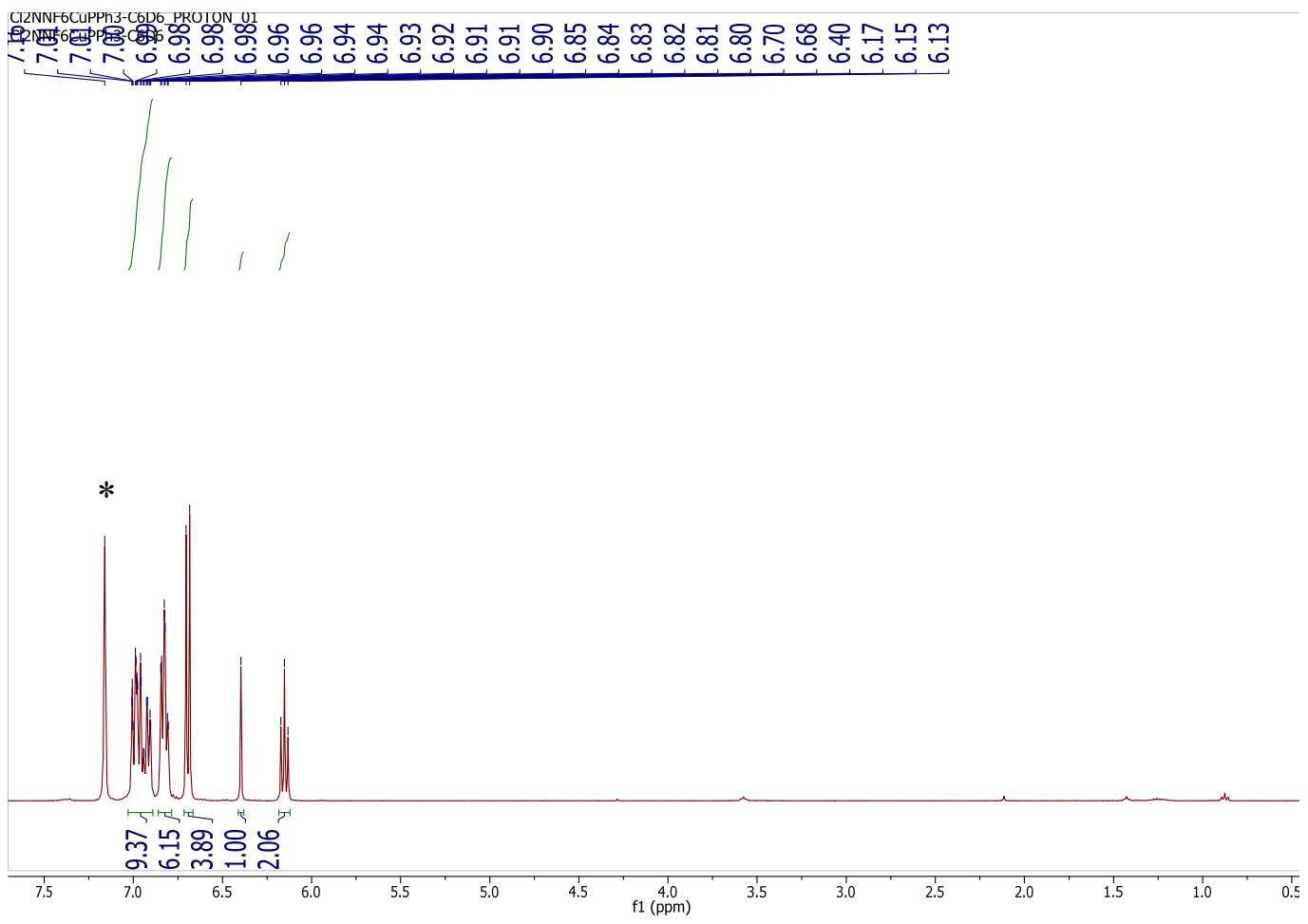

Figure S7. ${ }^{1} \mathrm{H}$ NMR spectrum $\left(400 \mathrm{MHz}, 298 \mathrm{~K}, \mathrm{C}_{6} \mathrm{D}_{6}\right)$ of 5. (* denotes residual proteo solvent impurities.) 


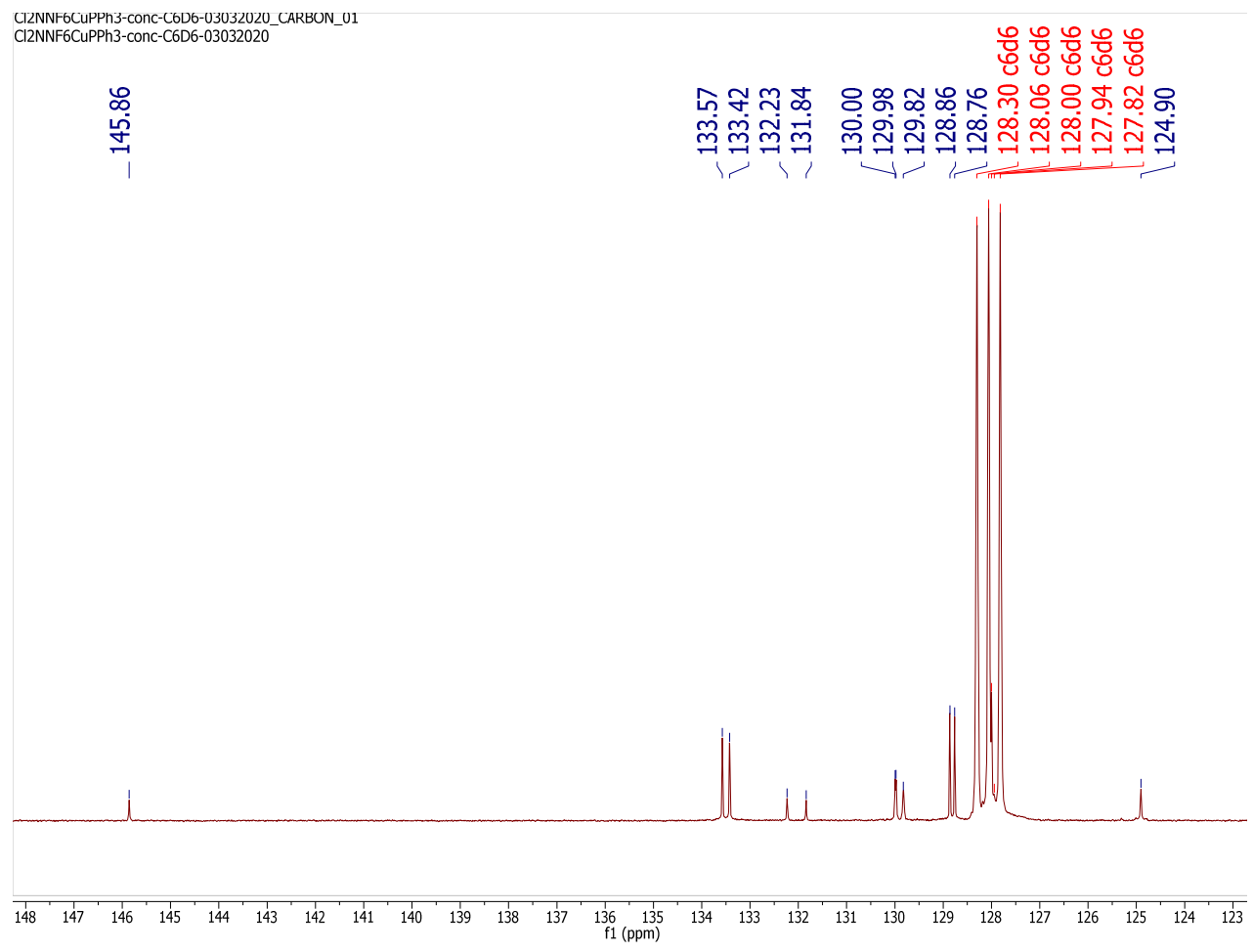

Figure S8. ${ }^{13} \mathrm{C}\left\{{ }^{1} \mathrm{H}\right\}$ NMR spectrum $\left(100 \mathrm{MHz}, 298 \mathrm{~K}, \mathrm{C}_{6} \mathrm{D}_{6}\right)$ of 5 .

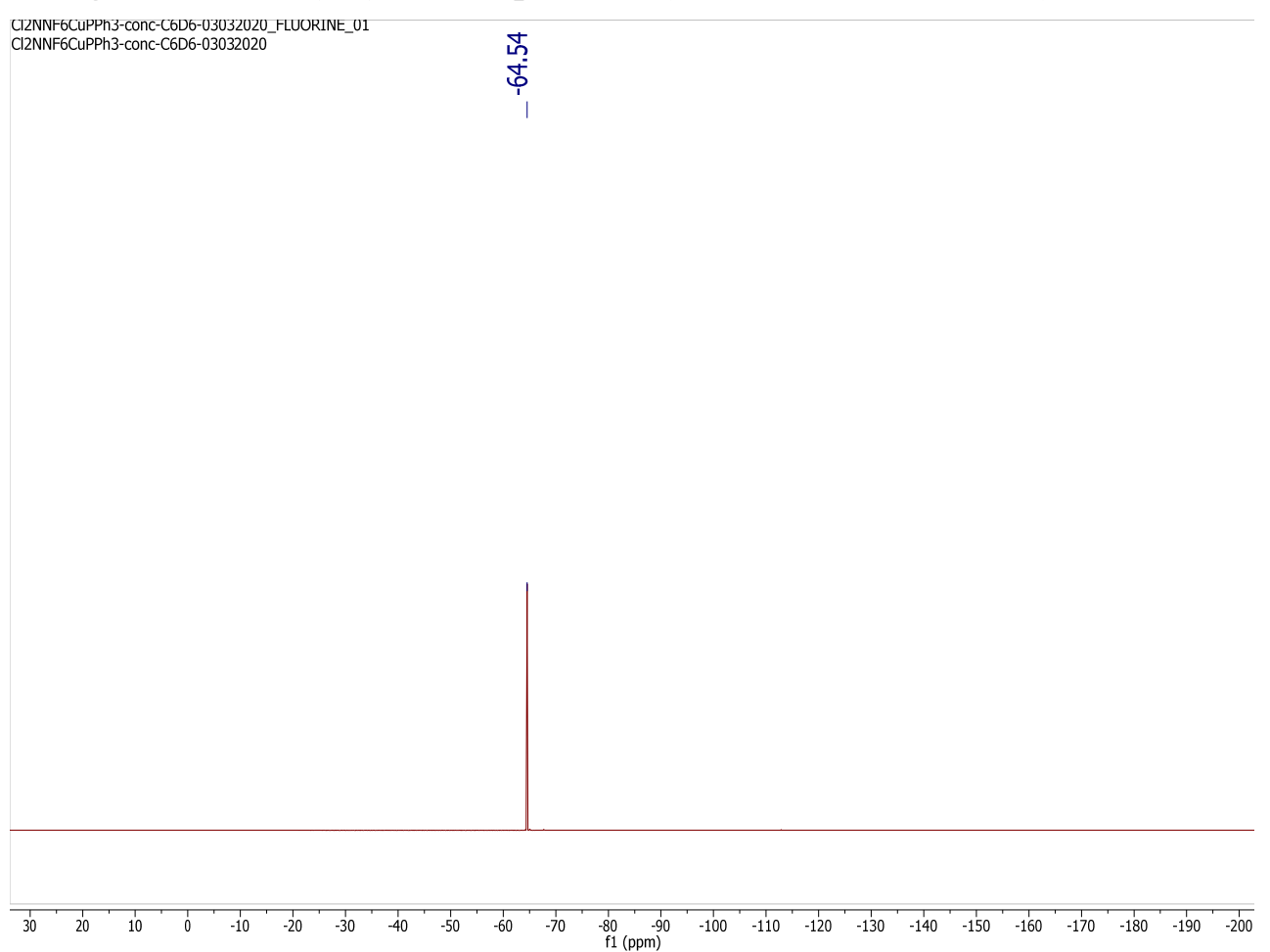

Figure S9. ${ }^{19} \mathrm{~F}$ NMR spectrum $\left(376 \mathrm{MHz}, 298 \mathrm{~K}, \mathrm{C}_{6} \mathrm{D}_{6}\right)$ of $\mathbf{5}$. 
MA71-CI2NNF6CUPPh3-XtaI-C6D6-111620_PHOSPHORUS_01 MA71-CI2NNF6CuPPh3-xtal-C6D6-111620

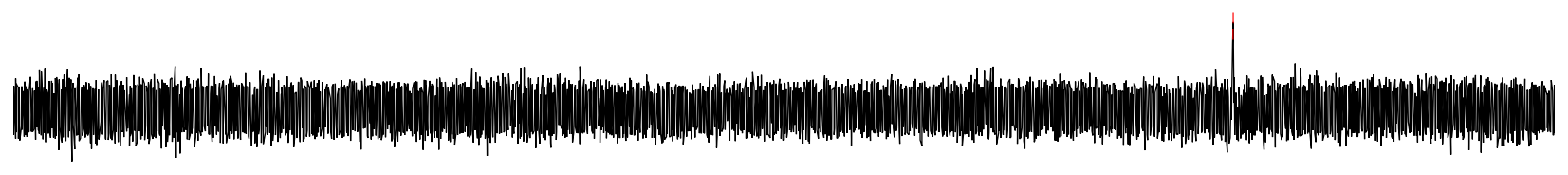

$\begin{array}{llllllllllllllllllllllllll}100 & 190 & 180 & 170 & 160 & 150 & 140 & 130 & 120 & 110 & 100 & 90 & \begin{array}{c}80 \\ \mathrm{f} 1(\mathrm{ppm})\end{array} & 70 & 50 & 40 & 30 & 20 & 10 & 0 & -10 & -20 & -30 & -40 & \end{array}$

Figure S10. ${ }^{31} \mathrm{P}$ NMR spectrum $\left(300 \mathrm{MHz}, 298 \mathrm{~K}, \mathrm{C}_{6} \mathrm{D}_{6}\right)$ of $\mathbf{5}$. 


\section{Synthesis and Characterization of $\left[\mathrm{Cl}_{2} \mathrm{NN}_{\mathrm{F} 6}\right] \mathrm{Cu}\left(\mathrm{P}\left(\mathrm{Ar}^{\mathrm{CF}}\right)_{3}\right)(6)$.}

A mixture of $\left\{\left[\mathrm{Cl}_{2} \mathrm{NN}_{\mathrm{F} 6}\right] \mathrm{Cu}\right\}_{2}$ (benzene) $(0.080 \mathrm{~g}, 0.067 \mathrm{mmol})$ and 2.1 equiv. $\mathrm{P}\left(\mathrm{Ar}^{\mathrm{CF} 3}\right)_{3}(0.067 \mathrm{~g}$, $0.1432 \mathrm{mmol})$ in anhydrous fluorobenzene $(5 \mathrm{~mL})$ was stirred at room temperature overnight. The resultant orange reaction mixture was filtered and crystallized at $-40{ }^{\circ} \mathrm{C}$ for $0.058 \mathrm{~g}$ of orange crystals for an 84\% yield. ${ }^{1} \mathrm{H} \mathrm{NMR}\left(400 \mathrm{MHz}, 298 \mathrm{~K}, \mathrm{C}_{6} \mathrm{D}_{6}\right): \delta 7.16$ (solvent), 7.09 (d, $6 \mathrm{H}, o-\mathrm{Ar}-H), 6.76(\mathrm{t}, 6 \mathrm{H}, m-\mathrm{Ar}-H), 6.62(\mathrm{~d}, 4 \mathrm{H}, m-\mathrm{Ar}-H), 6.40(\mathrm{~s}, 1 \mathrm{H}$, backbone-CH), $6.16(\mathrm{~d}$, $2 \mathrm{H}, p$-Ar- $H$ ). ${ }^{19} \mathrm{~F}$ NMR (376 MHz, $\mathrm{C}_{6} \mathrm{D}_{6}$ ): $\delta$-63.72 (s, standard), -64.24 (s, phosphine-CF3), 65.83 (s, backbone-CF3). ${ }^{13} \mathrm{C}\left\{{ }^{1} \mathrm{H}\right\}$ NMR $\left(100 \mathrm{MHz}, \mathrm{C}_{6} \mathrm{D}_{6}\right): \delta 145.68,134.93,134.56,133.78$, 133.62, 132.81, 132.49, 129.70, 125.91, 125.36. ${ }^{31} \mathrm{P} \mathrm{NMR}\left(300 \mathrm{MHz}, \mathrm{C}_{6} \mathrm{D}_{6}\right): \delta$ 78.76. Anal. Calcd for $\mathrm{C}_{42} \mathrm{H}_{37} \mathrm{CuF}_{9} \mathrm{~N}_{2} \mathrm{P}$ : C, 44.53; H, 1.87; N, 2.73. Found: C, 43.90; H, 2.03; N, 2.77 .

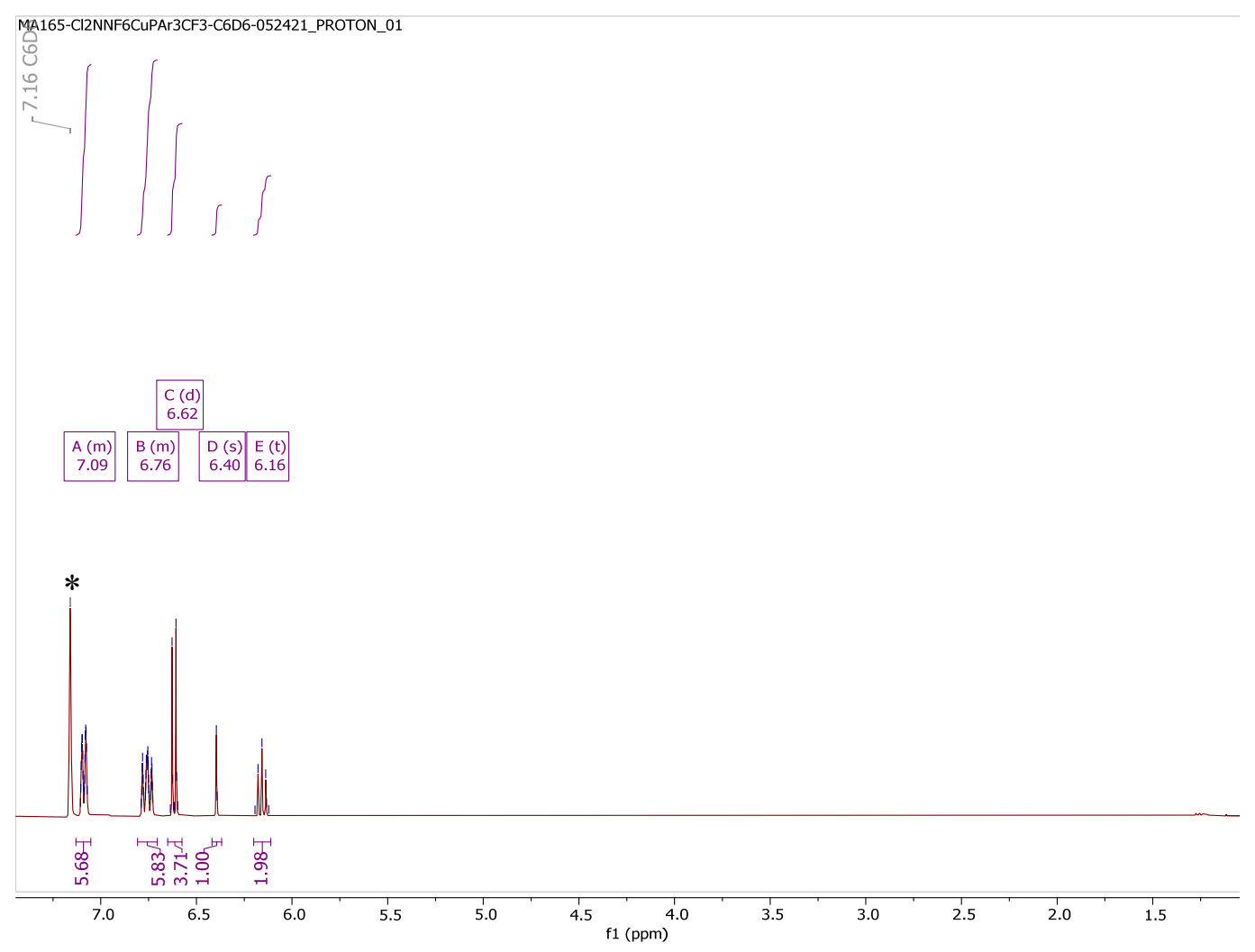

Figure S11. ${ }^{1} \mathrm{H}$ NMR spectrum $\left(400 \mathrm{MHz}, 298 \mathrm{~K}, \mathrm{C}_{6} \mathrm{D}_{6}\right)$ of 6. (* $^{*}$ denotes residual proteo solvent impurities.) 


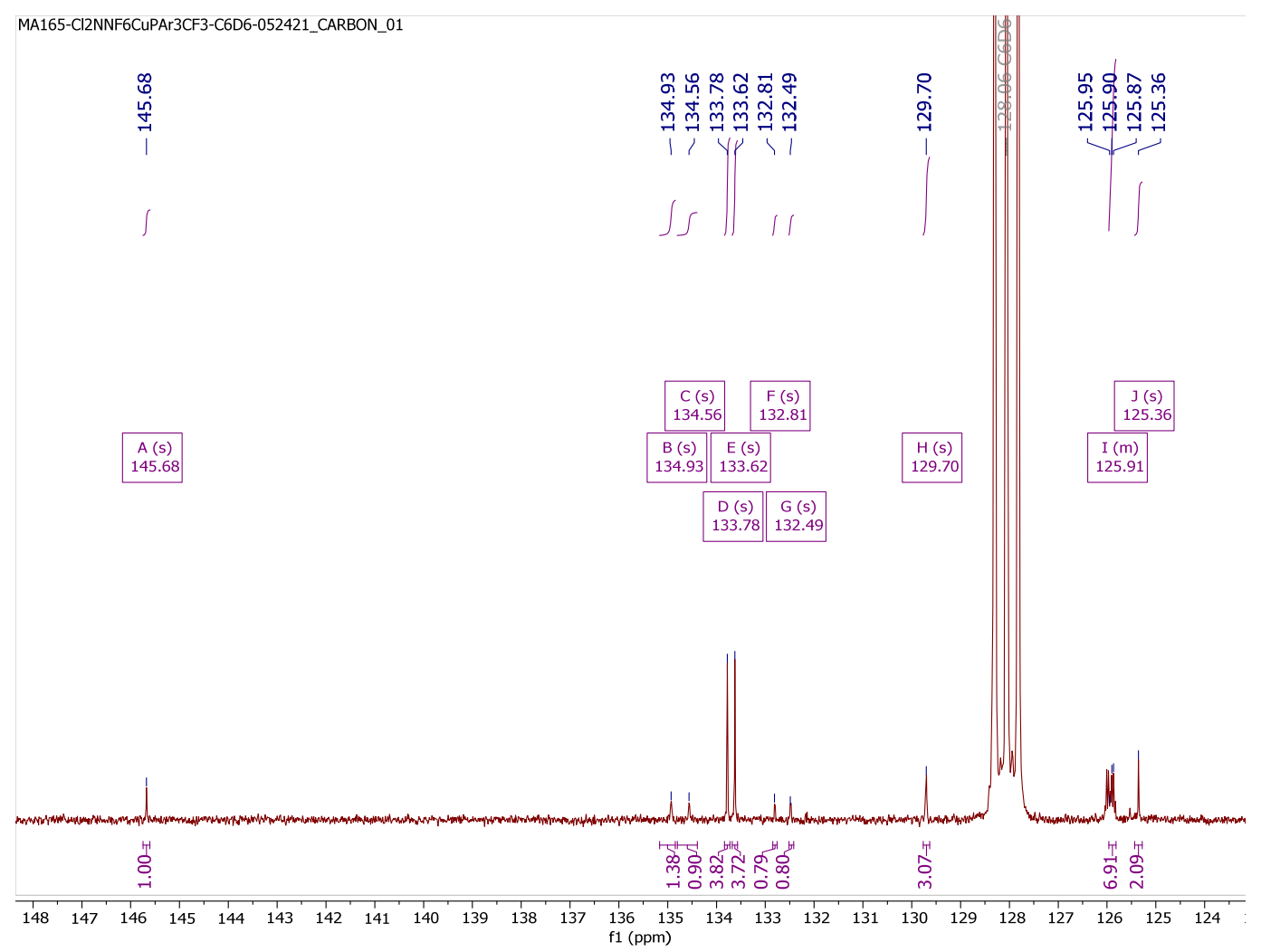

Figure S12. ${ }^{13} \mathrm{C}\left\{{ }^{1} \mathrm{H}\right\}$ NMR spectrum $\left(100 \mathrm{MHz}, 298 \mathrm{~K}, \mathrm{C}_{6} \mathrm{D}_{6}\right)$ of 6 .

Figure S13. ${ }^{19} \mathrm{~F}$ NMR spectrum $\left(376 \mathrm{MHz}, 298 \mathrm{~K}, \mathrm{C}_{6} \mathrm{D}_{6}\right)$ of 6. 


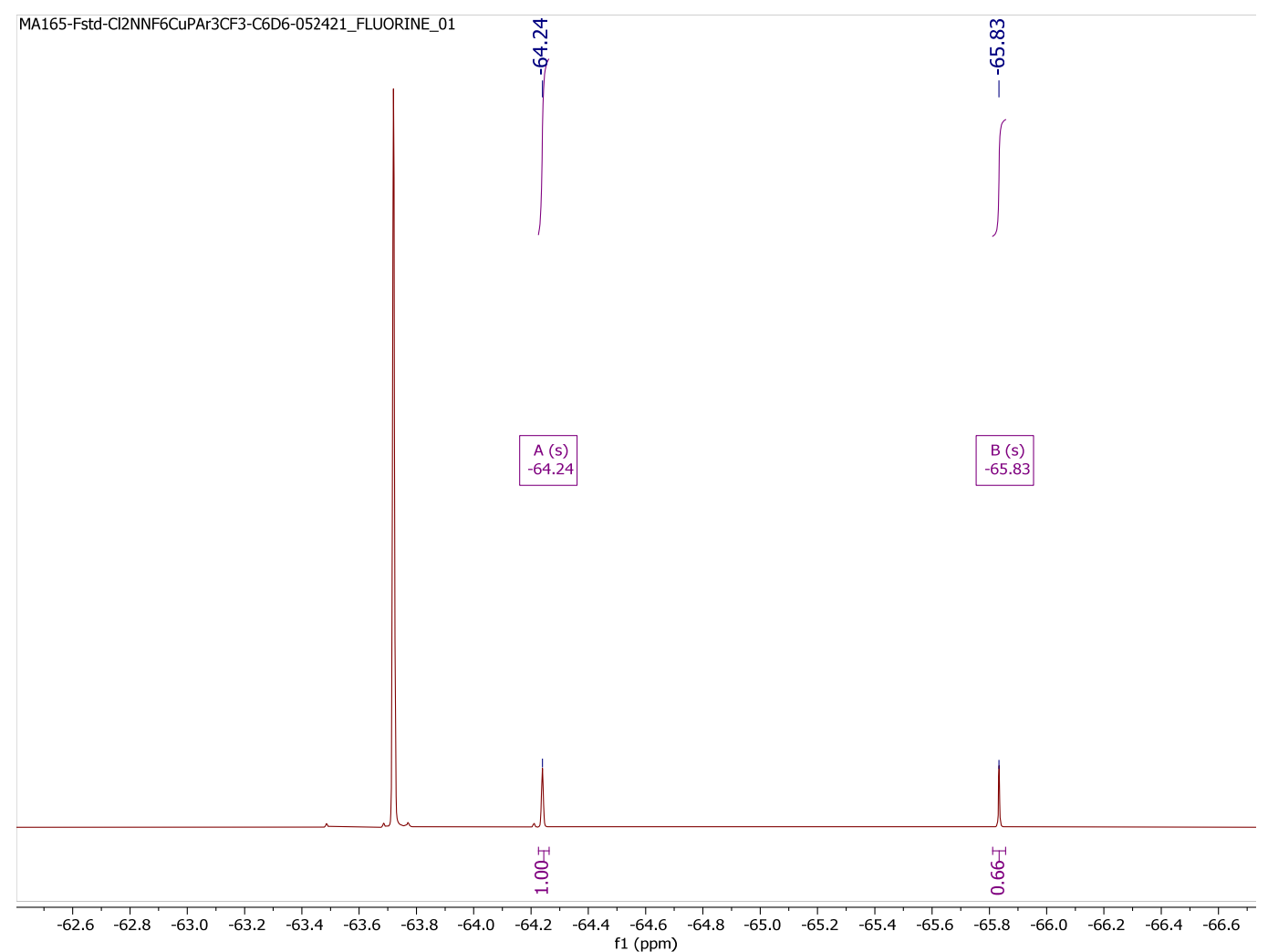




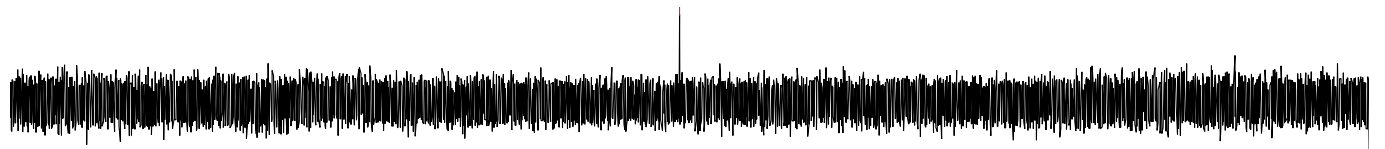

$\begin{array}{lllllllllllllllllllllllllllllllll}190 & 180 & 170 & 160 & 150 & 140 & 130 & 120 & 110 & 100 & 90 & \begin{array}{c}80 \\ \mathrm{f} 1(\mathrm{ppm})\end{array} & 70 & 50 & 40 & 30 & 20 & 10 & 0 & -10 & -20 & -30 & -40\end{array}$

Figure S14. ${ }^{31} \mathrm{P}$ NMR spectrum $\left(300 \mathrm{MHz}, 298 \mathrm{~K}, \mathrm{C}_{6} \mathrm{D}_{6}\right)$ of 6. 


\section{Electrochemistry}

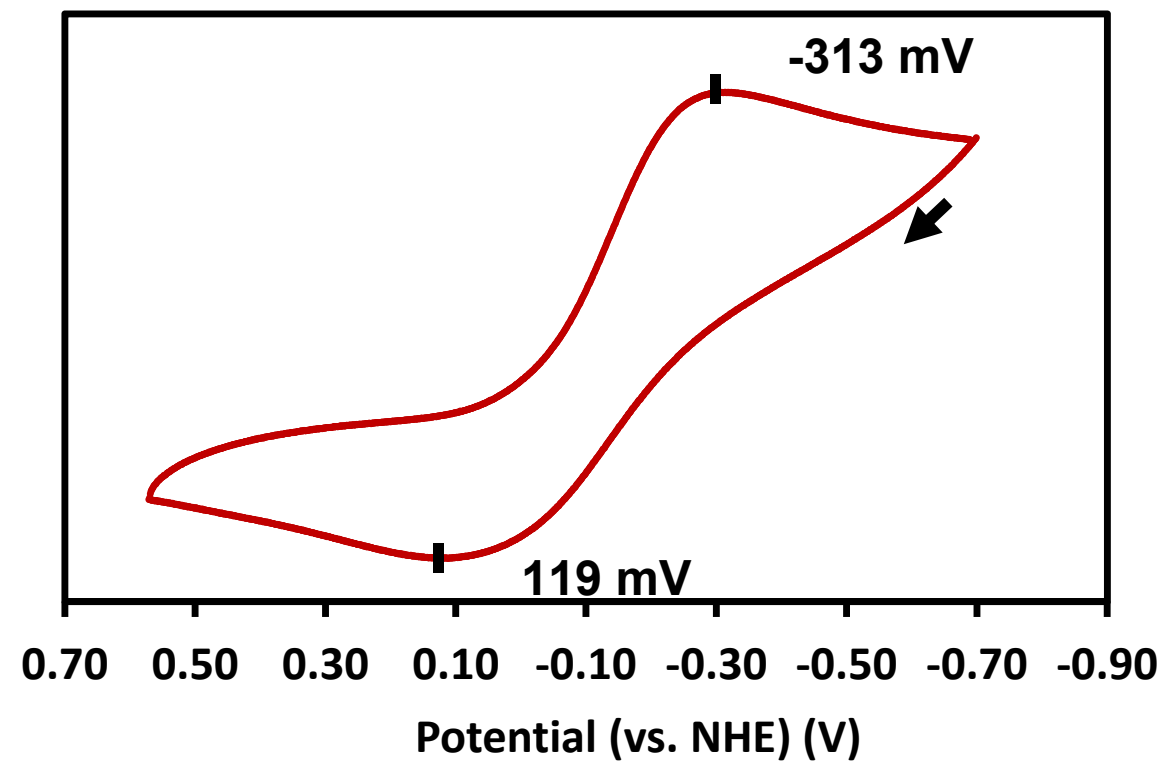

Figure S15. Cyclic voltammogram of $\left[\mathrm{Me}_{2} \mathrm{NN}_{\mathrm{F} 6}\right] \mathrm{Cu}\left(\kappa^{2}-\mathrm{O}_{2} \mathrm{~N}\right)(2)\left(1.0 \mathrm{mM}\right.$ in $\mathrm{THF}$ at $\left.25{ }^{\circ} \mathrm{C}\right)$ in presence of $n$-tetrabutyl ammonium hexafluorophosphate $(0.1 \mathrm{M})$. Scan proceeds in the indicated direction with scan rate of $50 \mathrm{mV} / \mathrm{s}$.

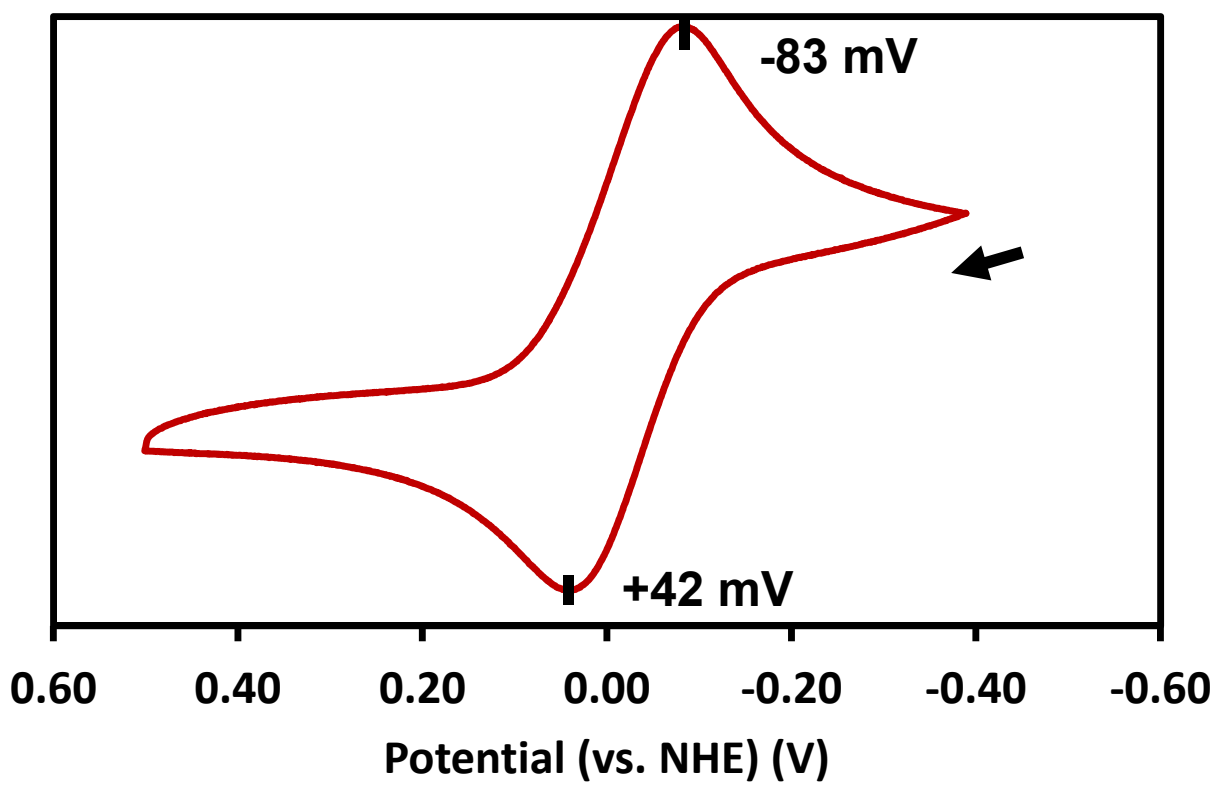

Figure S16. Cyclic voltammogram of $\left[\mathrm{Cl}_{2} \mathrm{NN}\right] \mathrm{Cu}\left(\kappa^{2}-\mathrm{O}_{2} \mathrm{~N}\right)(3)\left(1.0 \mathrm{mM}\right.$ in THF at $\left.25{ }^{\circ} \mathrm{C}\right)$ in presence of $n$-tetrabutyl ammonium hexafluorophosphate $(0.1 \mathrm{M})$. Scan proceeds in the indicated direction with scan rate of $50 \mathrm{mV} / \mathrm{s}$. 


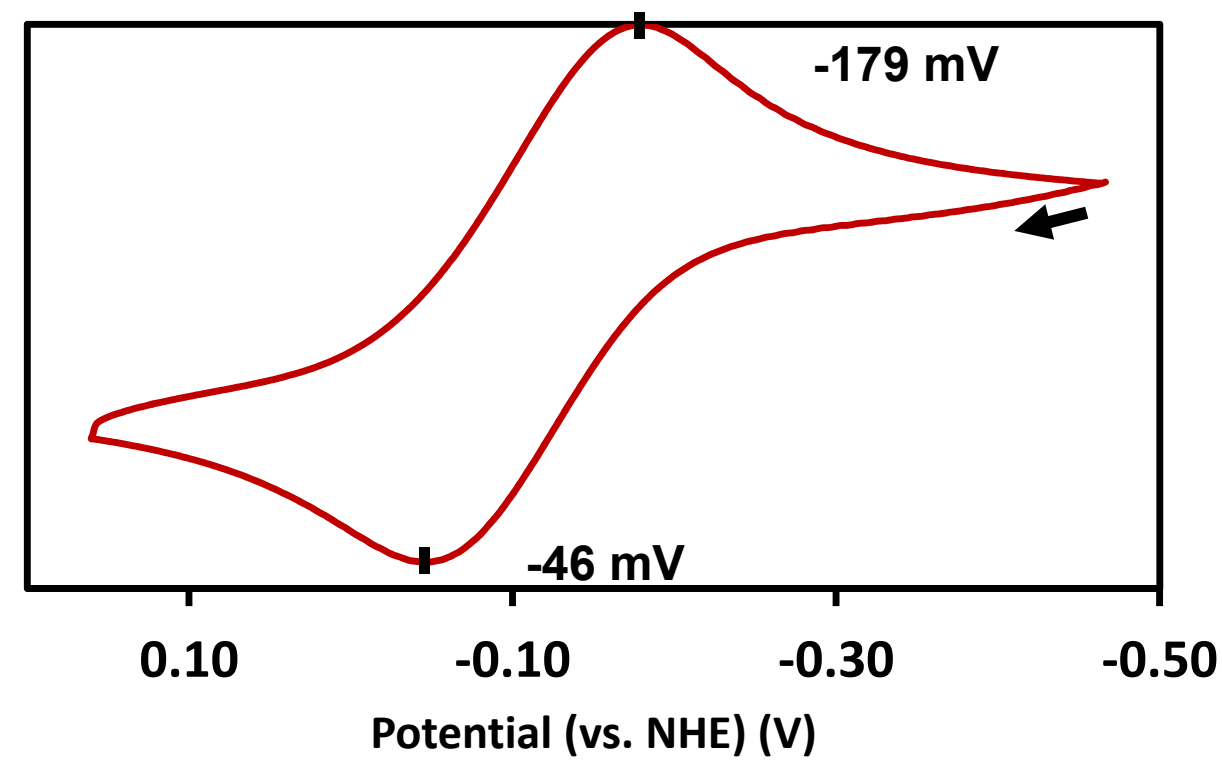

Figure S17. Cyclic voltammogram of $\left[\mathrm{Me}_{2} \mathrm{NN}\right] \mathrm{Cu}\left(\kappa^{2}-\mathrm{O}_{2} \mathrm{~N}\right)(4)\left(1.0 \mathrm{mM}\right.$ in $\mathrm{THF}$ at $\left.25^{\circ} \mathrm{C}\right)$ in presence of $n$-tetrabutyl ammonium hexafluorophosphate $(0.1 \mathrm{M})$. Scan proceeds in the indicated direction with scan rate of $50 \mathrm{mV} / \mathrm{s}$.

Table S1. Electrochemical data for 1-4

\begin{tabular}{|c|c|}
\hline Copper Complex & Reduction Potential (V v. NHE) in THF \\
\hline$\left[\mathrm{Cl}_{2} \mathrm{NN}_{\mathrm{F} 6}\right] \mathrm{Cu}\left(\kappa^{2}-\mathrm{O}_{2} \mathrm{~N}\right)(1)$ & $0.331^{1}$ \\
\hline$\left[\mathrm{Me}_{2} \mathrm{NN}_{\mathrm{F} 6}\right] \mathrm{Cu}\left(\kappa^{2}-\mathrm{O}_{2} \mathrm{~N}\right)(2)$ & 0.303 \\
\hline$\left[\mathrm{Cl}_{2} \mathrm{NN}\right] \mathrm{Cu}\left(\kappa^{2}-\mathrm{O}_{2} \mathrm{~N}\right)(3)$ & -0.021 \\
\hline$\left[\mathrm{Me}_{2} \mathrm{NN}\right] \mathrm{Cu}\left(\kappa^{2}-\mathrm{O}_{2} \mathrm{~N}\right)(4)$ & -0.113 \\
\hline
\end{tabular}




\section{Reaction of $\left[\mathrm{Cl}_{2} \mathrm{NN}_{\mathrm{F} 6}\right] \mathrm{Cu}^{\mathrm{II}}\left(\kappa^{2}-\mathrm{O}_{2} \mathrm{~N}\right)(1)$ with 1 and 2 equiv. of $\mathrm{P}\left(\mathrm{Ar}^{\mathrm{CF} 3}\right)_{3}$}

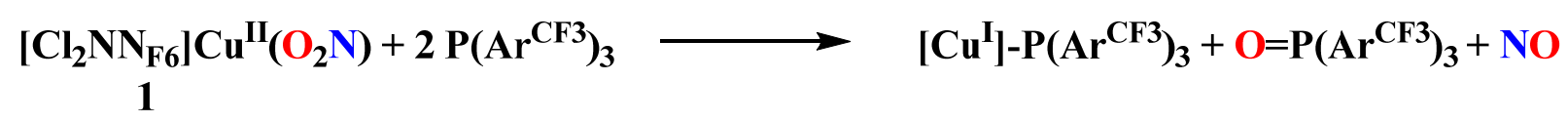

Scheme S1. Reaction between 1 and phosphine generates nitric oxide and phosphine oxide.

To a solution of 1 in $\mathrm{C}_{6} \mathrm{D}_{6}(0.5 \mathrm{~mL}$ of $33.0 \mathrm{mM}$ solution, $0.0165 \mathrm{mmol})$ was added a $\mathrm{C}_{6} \mathrm{D}_{6}$ solution containing 1 equiv. tris(4-(trifluoromethyl)phenyl)phosphine $\left(\mathrm{P}\left(\mathrm{Ar}^{\mathrm{CF} 3}\right)_{3}\right)(0.2 \mathrm{~mL}$ of $82.6 \mathrm{mM}$ solution, $0.0165 \mathrm{mmol}$ ). A trifluorotoluene standard was also added ( 8 equiv.) The color of the solution changed from dark green to yellow. After $1.5 \mathrm{~h}$ the resultant solution was analyzed by ${ }^{19} \mathrm{~F}$ NMR spectroscopy, which showed the formation of 6 in $46 \%$ yield as judged by the resonance at $-65.85 \mathrm{ppm} . \mathrm{O}=\mathrm{P}\left(\mathrm{Ar}^{\mathrm{CF} 3}\right)_{3}$ was formed in $30 \%$ yield as judged by the resonance at $-64.32 \mathrm{ppm}$. The procedure was repeated with 2 equiv. tris(4(trifluoromethyl)phenyl)phosphine $(0.4 \mathrm{~mL}$ of $82.6 \mathrm{mM}$ solution, $0.0330 \mathrm{mmol})$ for a yield of $72 \%$ of 6. $\mathrm{O}=\mathrm{P}\left(\mathrm{Ar}^{\mathrm{CF} 3}\right)_{3}$ was formed in $64 \%$ yield. ${ }^{19} \mathrm{~F}$ NMR $\left(376 \mathrm{MHz}, \mathrm{C}_{6} \mathrm{D}_{6}\right): \delta-63.72(\mathrm{~s}$, standard), -64.24 (s, phosphine-CF3), -64.32 (s, $\left.\mathrm{O}=\mathrm{P}\left(\mathrm{Ar}^{\mathrm{C} F 3}\right)_{3}\right)-65.83$ (s, backbone- $\mathrm{C} F 3$ ).

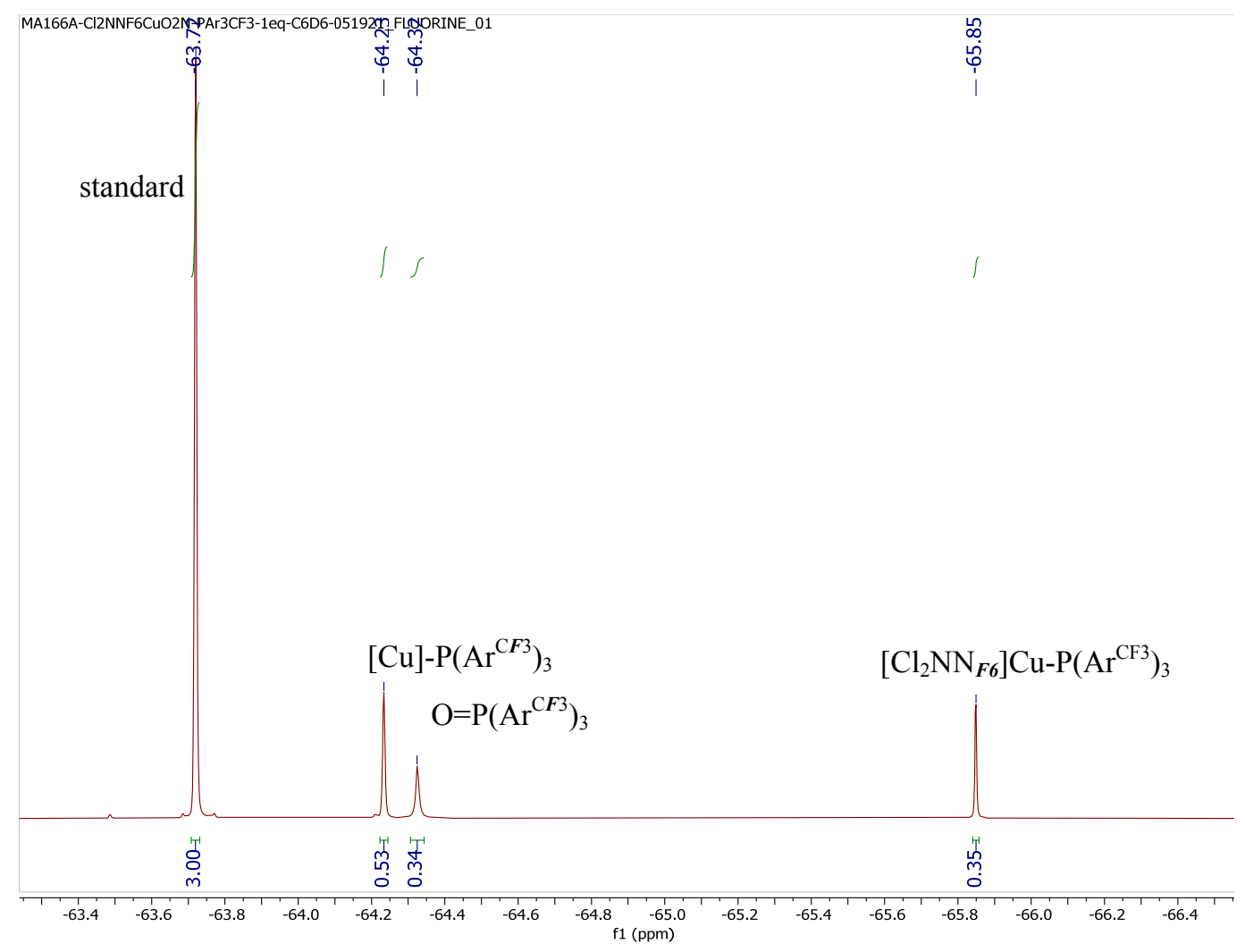

Figure S18. ${ }^{19} \mathrm{~F}$ NMR spectrum $\left(376 \mathrm{MHz}, 298 \mathrm{~K}, \mathrm{C}_{6} \mathrm{D}_{6}\right)$ of crude reaction mixture obtained from the reaction of 1 and 1 equiv. $\mathrm{P}\left(\mathrm{Ar}^{\mathrm{CF} 3}\right)_{3}$. 


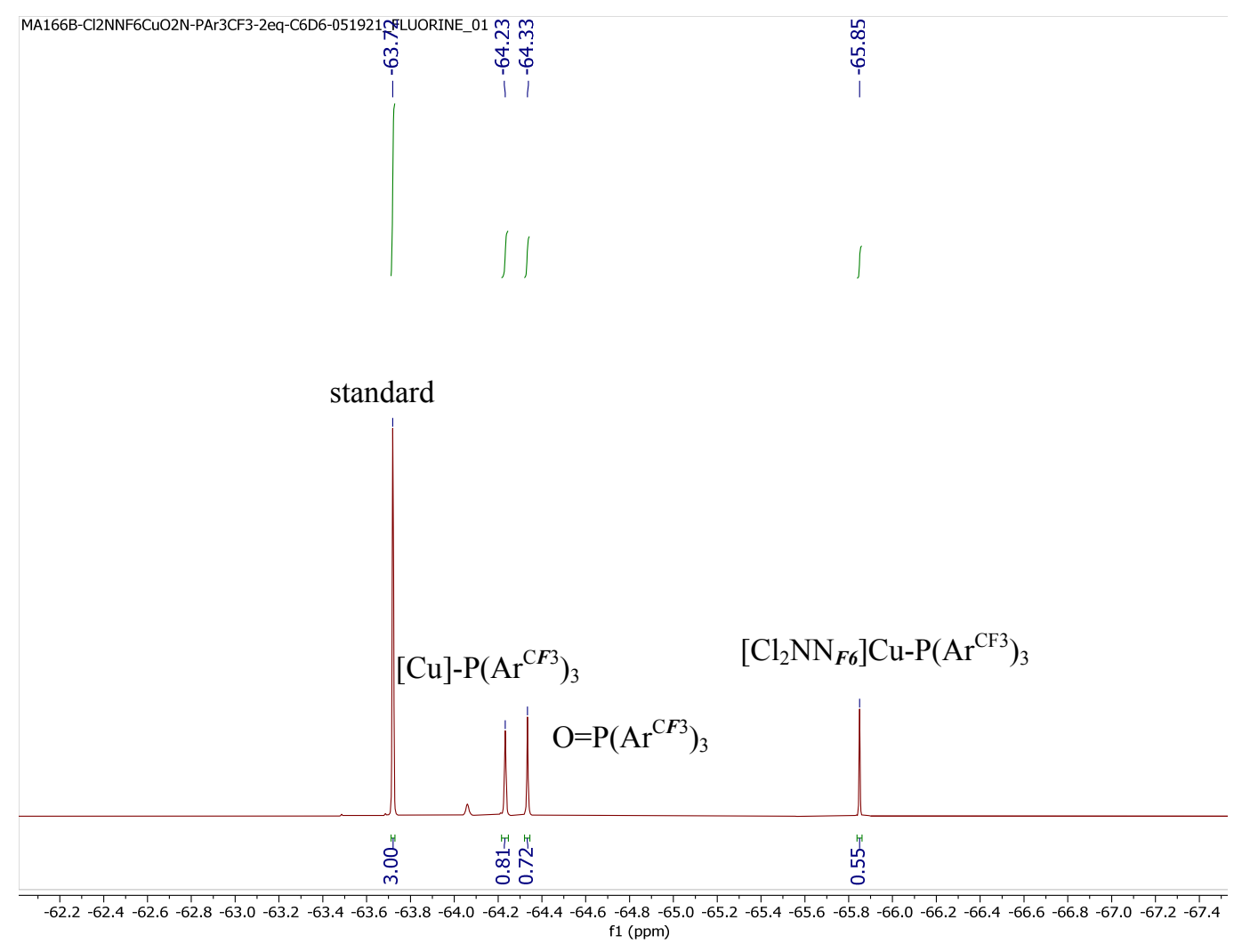

Figure S19. ${ }^{19} \mathrm{~F}$ NMR spectrum $\left(376 \mathrm{MHz}, 298 \mathrm{~K}, \mathrm{C}_{6} \mathrm{D}_{6}\right)$ of crude reaction mixture obtained from the reaction of 1 and 2 equiv. $\mathrm{P}\left(\mathrm{Ar}^{\mathrm{CF} 3}\right)_{3}$. 
10. NO Capture from $\left[\mathrm{Cl}_{2} \mathrm{NN}_{\mathrm{F} 6}\right] \mathrm{Cu}\left(\kappa^{2}-\mathrm{O}_{2} \mathrm{~N}\right)(1)$ and $\mathrm{PPh}_{3}$ with $\mathrm{Co}[\mathrm{T}(\mathrm{OMe}) \mathrm{PP}]$

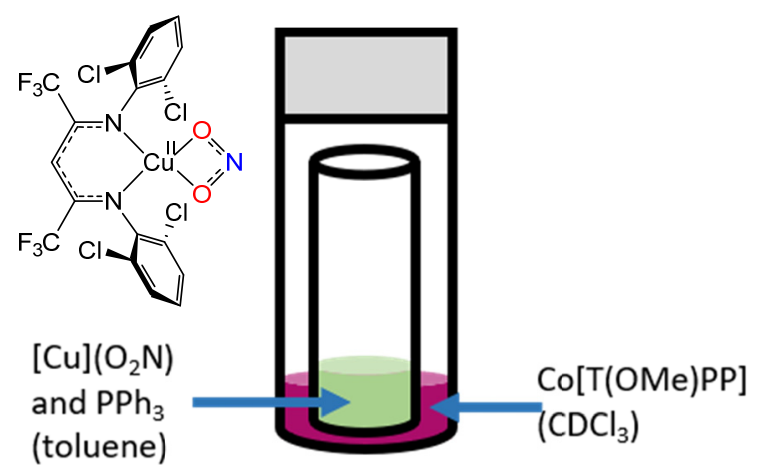

Figure S20. Experimental set up for NO capture.

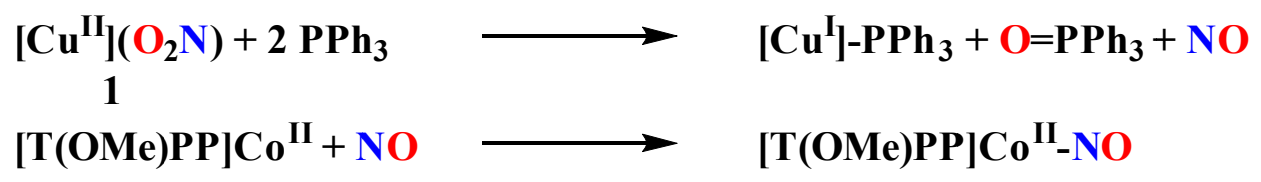

Scheme S2. Reaction between 1 and phosphine generates nitric oxide which binds to cobalt.

Nitric oxide production was quantified similarly to previously published procedures. ${ }^{2,4}$ A vial within a vial set up was used with the outer vial sealed with a septum and the inner vial left open. In the small vial $\left[\mathrm{Cl}_{2} \mathrm{NN}_{\mathrm{F}}\right] \mathrm{Cu}\left(\kappa^{2}-\mathrm{O}_{2} \mathrm{~N}\right)(\mathbf{1})(0.024 \mathrm{~g}, 0.040 \mathrm{mmol})$ and $\mathrm{PPh}_{3}(0.036 \mathrm{~g}, 0.137$ mmol) were added with a stir bar but without solvent while in the outer vial [T(OMe)PP]Co ${ }^{\mathrm{II}}$ in $\mathrm{CDCl}_{3}(0.038 \mathrm{~g}, 0.048 \mathrm{mmol})$ was readied to capture released NO from the reaction. Toluene was injected through the septum into the inner vial to initiate the reaction and it was allowed to stir overnight and quantified via ${ }^{1} \mathrm{H}$ NMR for a $64 \%$ yield. 


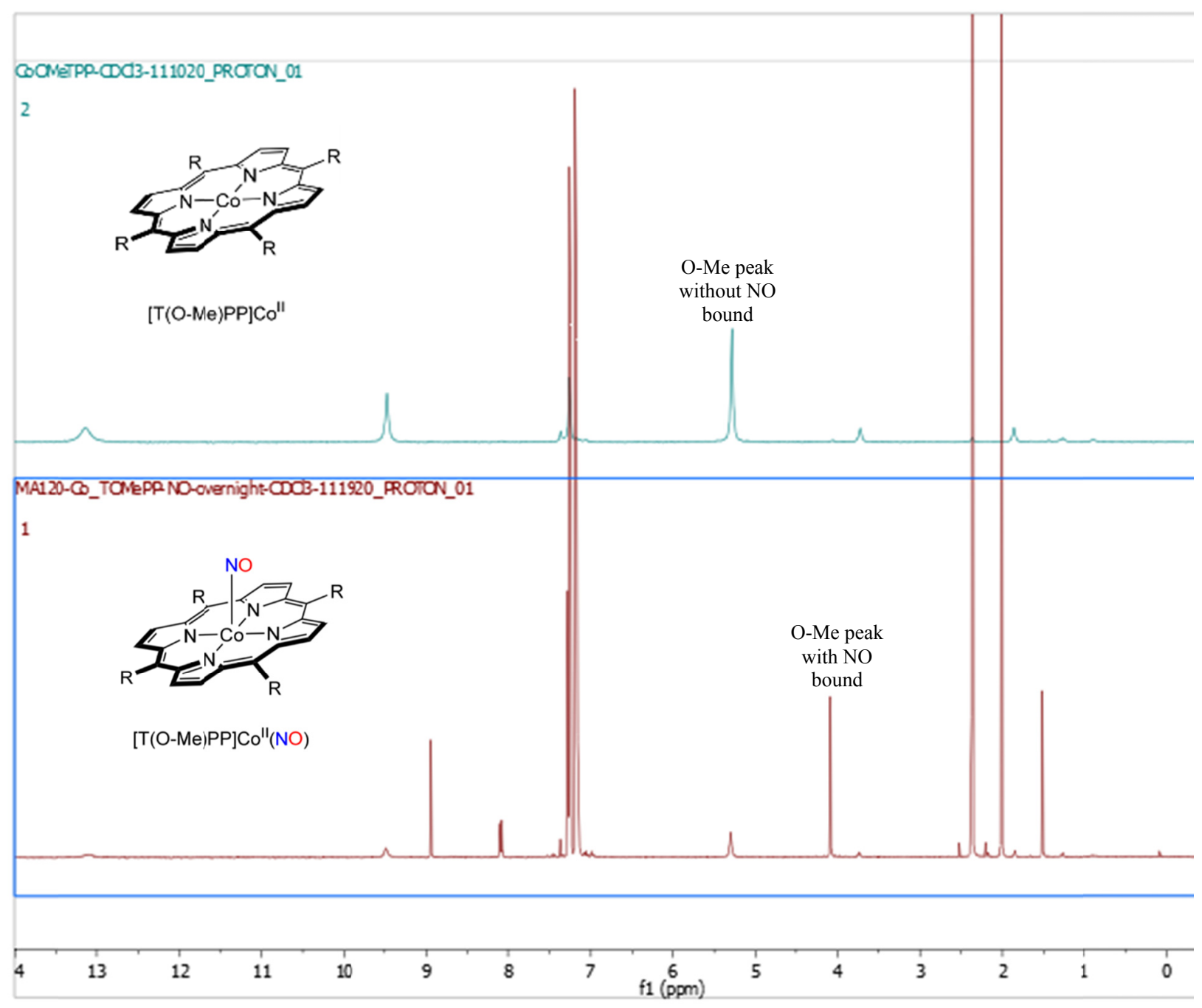

Figure S21. ${ }^{1} \mathrm{H}$ NMR spectrum of [T(OMe)PP]Co ${ }^{\mathrm{II}}(\mathrm{NO})(400 \mathrm{MHz}, 298 \mathrm{~K}$, $\left.\mathrm{CDCl}_{3}\right)$. 


\section{NO Capture from $\left[\mathrm{Cl}_{2} \mathrm{NN}_{\mathrm{F} 6}\right] \mathrm{Cu}\left(\kappa^{2}-\mathrm{O}_{2} \mathrm{~N}\right)(1)$ and $\mathrm{P}\left(\mathrm{Ar}^{\mathrm{CF} 3}\right)_{3}$ with $\mathrm{Co}[\mathrm{T}(\mathrm{OMe}) \mathrm{PP}]$}

Nitric oxide production was quantified similarly to previously published procedures. ${ }^{2,4} \mathrm{~A}$ vial within a vial set up was used with the outer vial sealed with a septum and the inner vial left open. In the small vial a solution of $\left[\mathrm{Cl}_{2} \mathrm{NN}_{\mathrm{F} 6}\right] \mathrm{Cu}\left(\kappa^{2}-\mathrm{O}_{2} \mathrm{~N}\right)(\mathbf{1})$ in toluene $(0.5 \mathrm{~mL}$ of $14 \mathrm{mM}$ solution, $0.0070 \mathrm{mmol})$ while in the outer vial $[\mathrm{T}(\mathrm{OMe}) \mathrm{PP}] \mathrm{Co}^{\mathrm{II}}$ in $\mathrm{CDCl}_{3}(1.0 \mathrm{~mL}$ of $0.0084 \mathrm{M}$ solution, $0.0084 \mathrm{mmol}$ ) was readied to capture released $\mathrm{NO}$ from the reaction. One equiv. of $\mathrm{P}\left(\mathrm{Ar}^{\mathrm{CF} 3}\right)_{3}$ in toluene $(0.2 \mathrm{~mL}$ of $0.035 \mathrm{M}$ solution, $0.0070 \mathrm{mmol})$ was injected through the septum into the inner vial to initiate the reaction and it was allowed to stir $2 \mathrm{~h}$ and quantified via ${ }^{1} \mathrm{H}$ NMR for a $51 \%$ yield. The reaction was repeated with 2 equiv. $\mathrm{P}\left(\mathrm{Ar}^{\mathrm{CF} 3}\right)_{3}(0.4 \mathrm{~mL}$ of $0.035 \mathrm{M}$ solution, $0.0140 \mathrm{mmol}$ ) for a $59 \%$ yield.

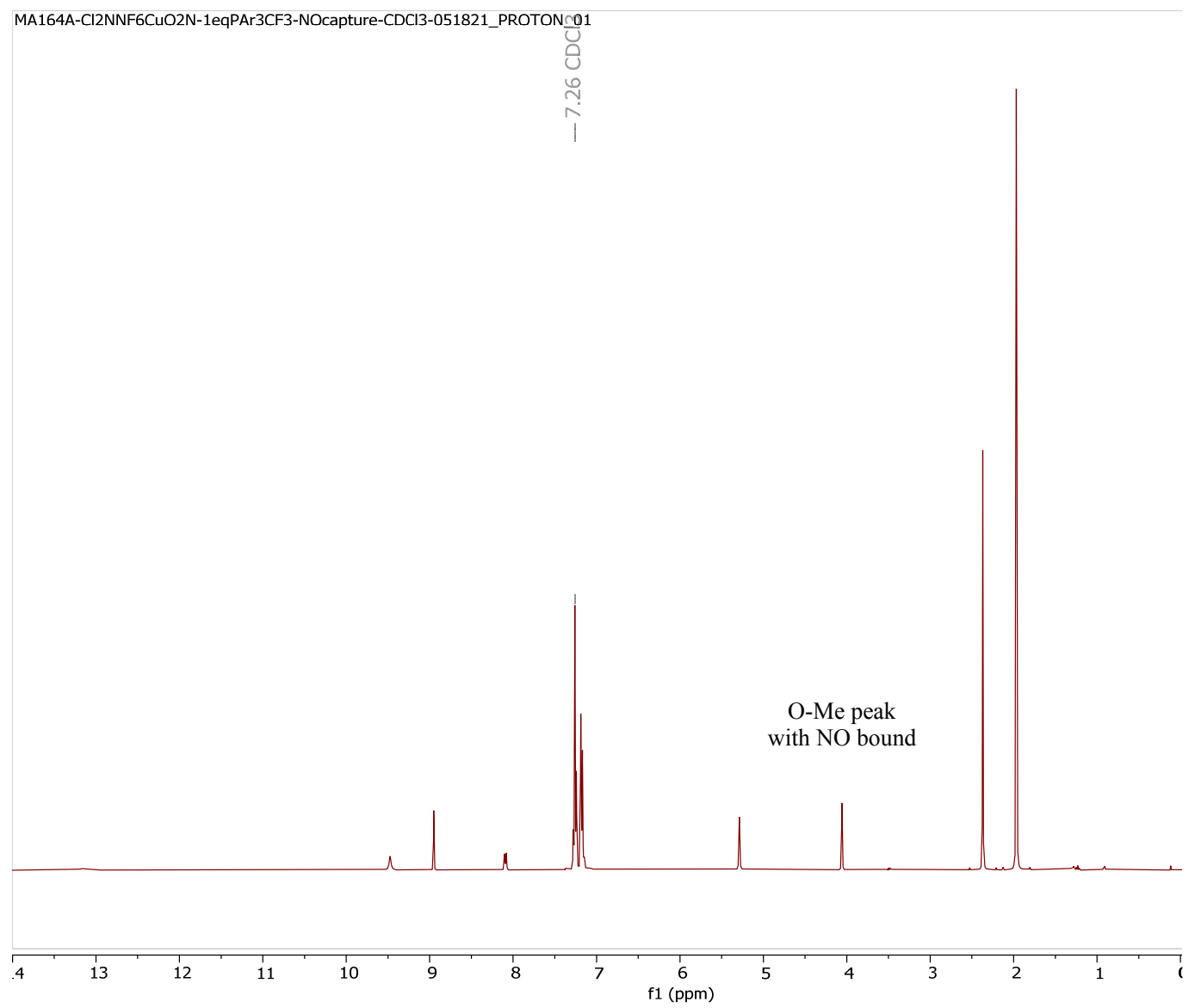

Figure S22. ${ }^{1} \mathrm{H}$ NMR spectrum of $[\mathrm{T}(\mathrm{OMe}) \mathrm{PP}] \mathrm{Co}{ }^{\mathrm{II}}(\mathrm{NO})$ from NO capture of reaction of 1 and 1 equiv. $\mathrm{P}\left(\mathrm{Ar}^{\mathrm{CF} 3}\right)_{3}\left(400 \mathrm{MHz}, 298 \mathrm{~K}, \mathrm{CDCl}_{3}\right)$. 


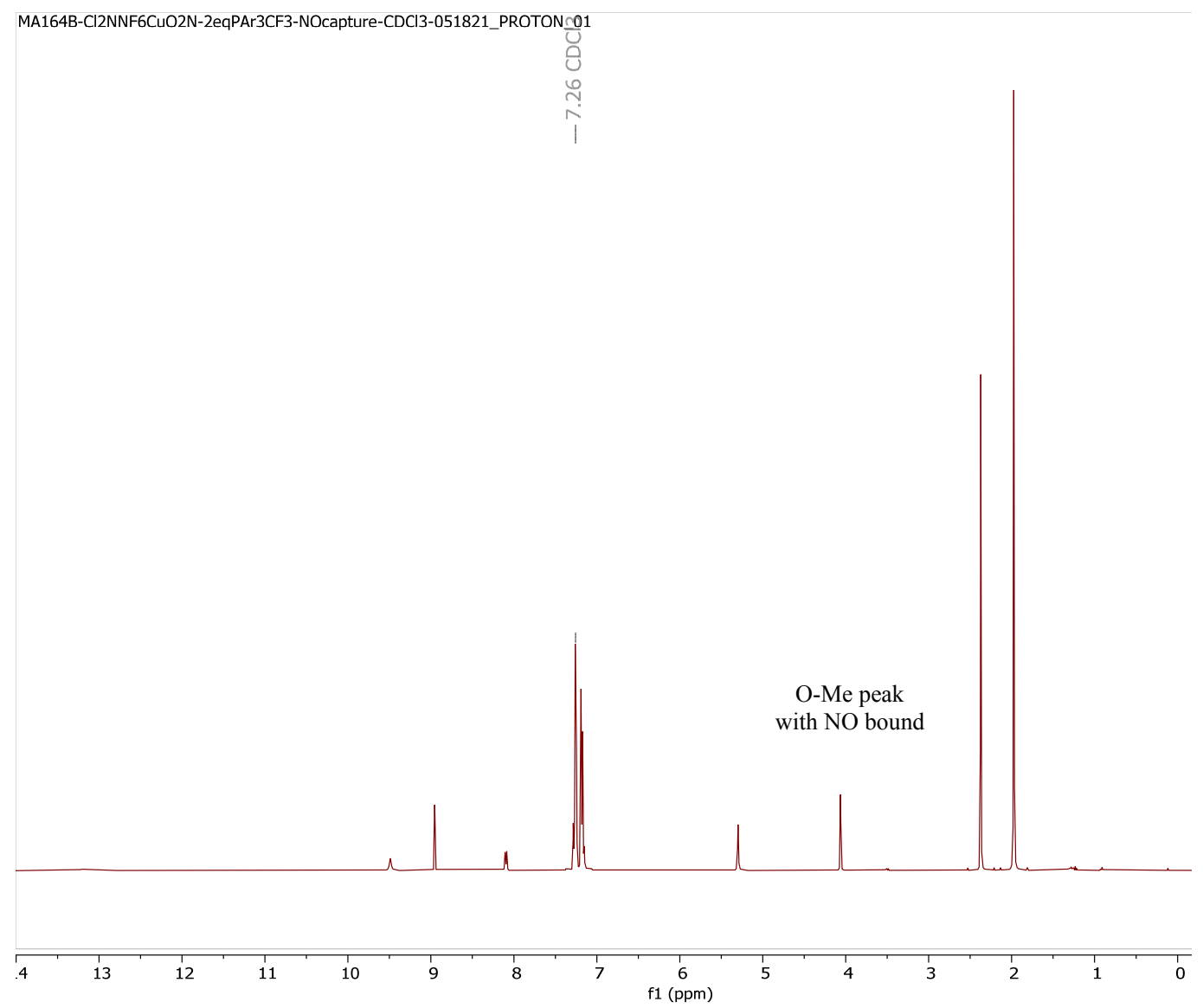

Figure S23. ${ }^{1} \mathrm{H}$ NMR spectrum of $[\mathrm{T}(\mathrm{OMe}) \mathrm{PP}] \mathrm{Co}^{\mathrm{II}}(\mathrm{NO})$ from NO capture of reaction of 1 and 2 equiv. $\mathrm{P}\left(\mathrm{Ar}^{\mathrm{CF} 3}\right)_{3}\left(400 \mathrm{MHz}, 298 \mathrm{~K}, \mathrm{CDCl}_{3}\right)$. 
12. Kinetic Analysis of Reaction of 1-4 with $\mathrm{P}\left(\mathrm{Ar}^{\mathrm{CF}}\right)_{3}$.

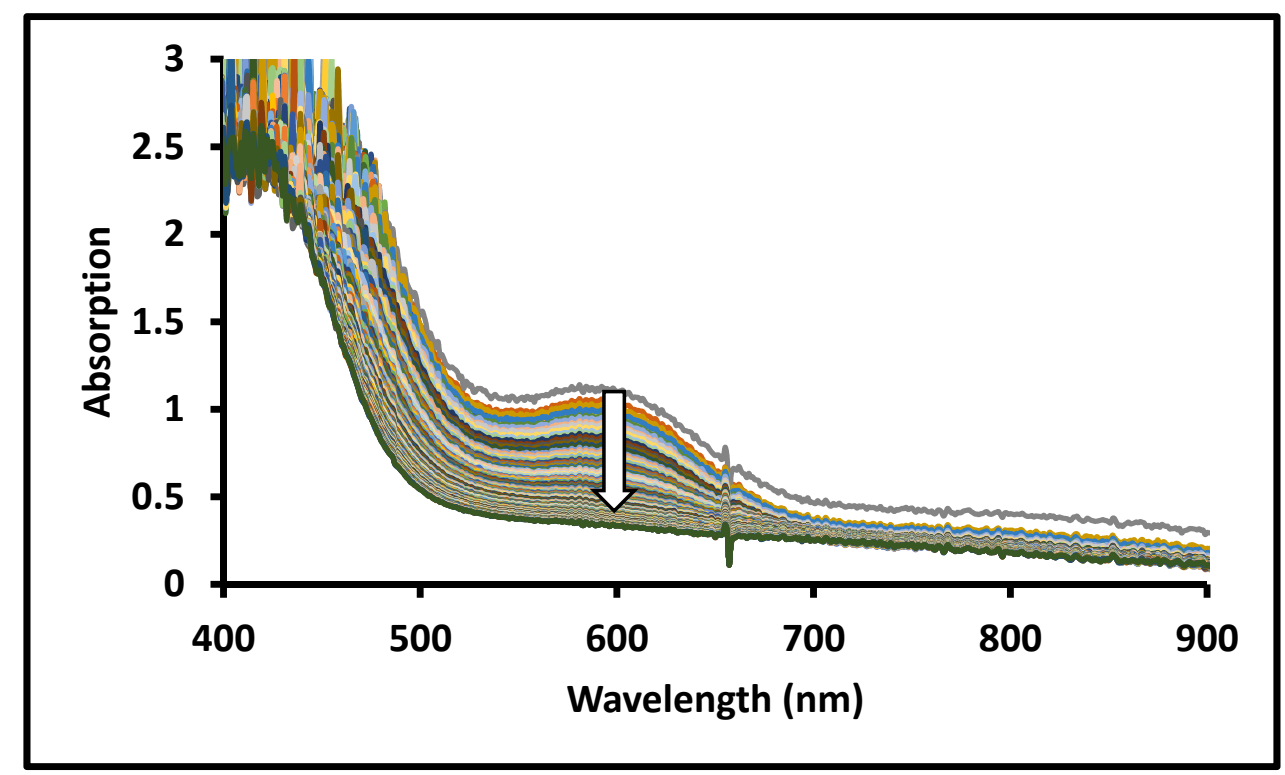

Figure S24. Typical full spectrum kinetics of $\left[\mathrm{Me}_{2} \mathrm{NN}_{\mathrm{F} 6}\right] \mathrm{Cu}\left(\kappa^{2}-\mathrm{O}_{2} \mathrm{~N}\right)(2)$ (initial concentration 2.0 $\mathrm{mM}$ ) reaction with 20 equiv. $\mathrm{P}\left(\mathrm{Ar}^{\mathrm{CF} 3}\right)_{3}$ in fluorobenzene at $-40{ }^{\circ} \mathrm{C}$ with spectra collected every 1 second for 250 seconds.

\section{Establishing Rate Law with $\left[\mathrm{Me}_{2} \mathrm{NN}_{\mathrm{F} 6}\right] \mathrm{Cu}\left(\kappa^{2}-\mathrm{O}_{2} \mathrm{~N}\right)(2)$ and $\mathrm{P}\left(\mathrm{Ar}^{\mathrm{CF} 3}\right)_{3}$ :}

The following stock solutions were prepared and stored at $-40{ }^{\circ} \mathrm{C}$ between experiments: $2.0 \mathrm{mM}$ $\left[\mathrm{Me}_{2} \mathrm{NN}_{\mathrm{F}}\right] \mathrm{Cu}\left(\kappa^{2}-\mathrm{O}_{2} \mathrm{~N}\right)$ (2) in toluene, $0.80 \mathrm{M} \mathrm{P}\left(\mathrm{Ar}^{\mathrm{CF} 3}\right)_{3}\left(\mathrm{Ar}^{\mathrm{CF} 3}=4-\mathrm{CF}_{3} \mathrm{C}_{6} \mathrm{H}_{4}\right)$ in toluene. Reactions were conducted in a UV-Vis cuvette: $2 \mathrm{~mL}$ of the copper solution was transferred to a cuvette inside the glove box and sealed with a septum which maintained a steady green color. $0.125-0.25 \mathrm{~mL}(25,30,40$, or 50 eq. $)$ of the phosphine solution was drawn into a syringe inside the glovebox as well. The cuvette was placed in the UV-vis equipped with the cryostat set to maintain the temperature at $-60^{\circ} \mathrm{C}$. The solution was allowed to stir for $\sim 10$ min to allow the temperature to be uniform. After $\sim 30 \mathrm{~s}$ collection the phosphine solution was injected. The drop of the peak at $600 \mathrm{~nm}$ was followed after the injection of the phosphine solution. The final color of the solution was yellow. 


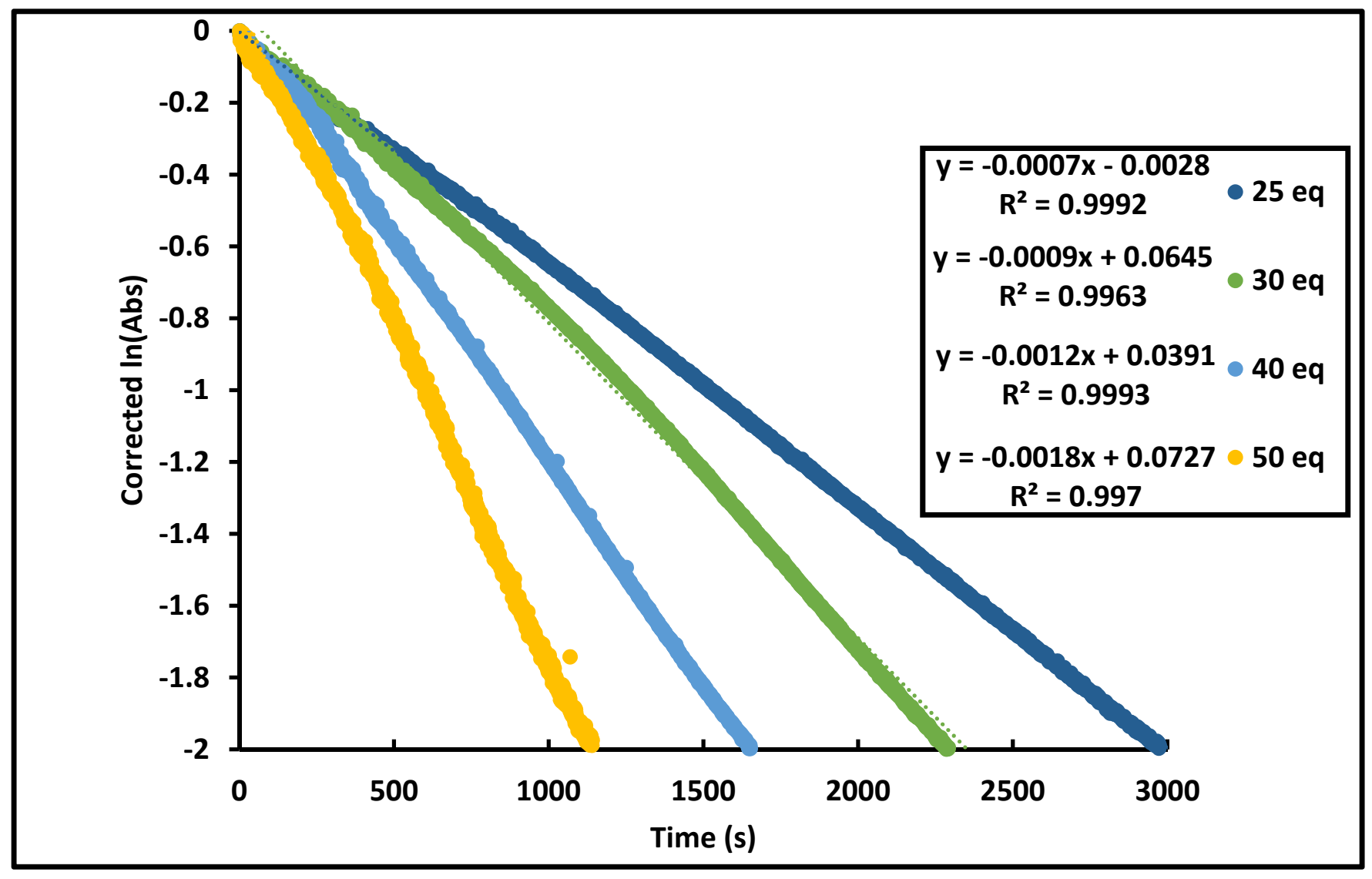

Figure S25. Kinetics of $\left[\mathrm{Me}_{2} \mathrm{NN}_{\mathrm{F} 6}\right] \mathrm{Cu}\left(\kappa^{2}-\mathrm{O}_{2} \mathrm{~N}\right)(2)$ (initial concentration $2.0 \mathrm{mM}$ ) reaction with $\mathrm{P}\left(\mathrm{Ar}^{\mathrm{CF} 3}\right)_{3}$ in toluene at $-60{ }^{\circ} \mathrm{C}$ as monitored through plots of $\ln \left[\left(\mathrm{A}_{\infty}-\mathrm{A}\right) /\left(\mathrm{A}_{\infty}-\mathrm{A}_{0}\right)\right]$ vs. time $(\mathrm{A}=$ absorbance at $\lambda=600 \mathrm{~nm}$ ). 


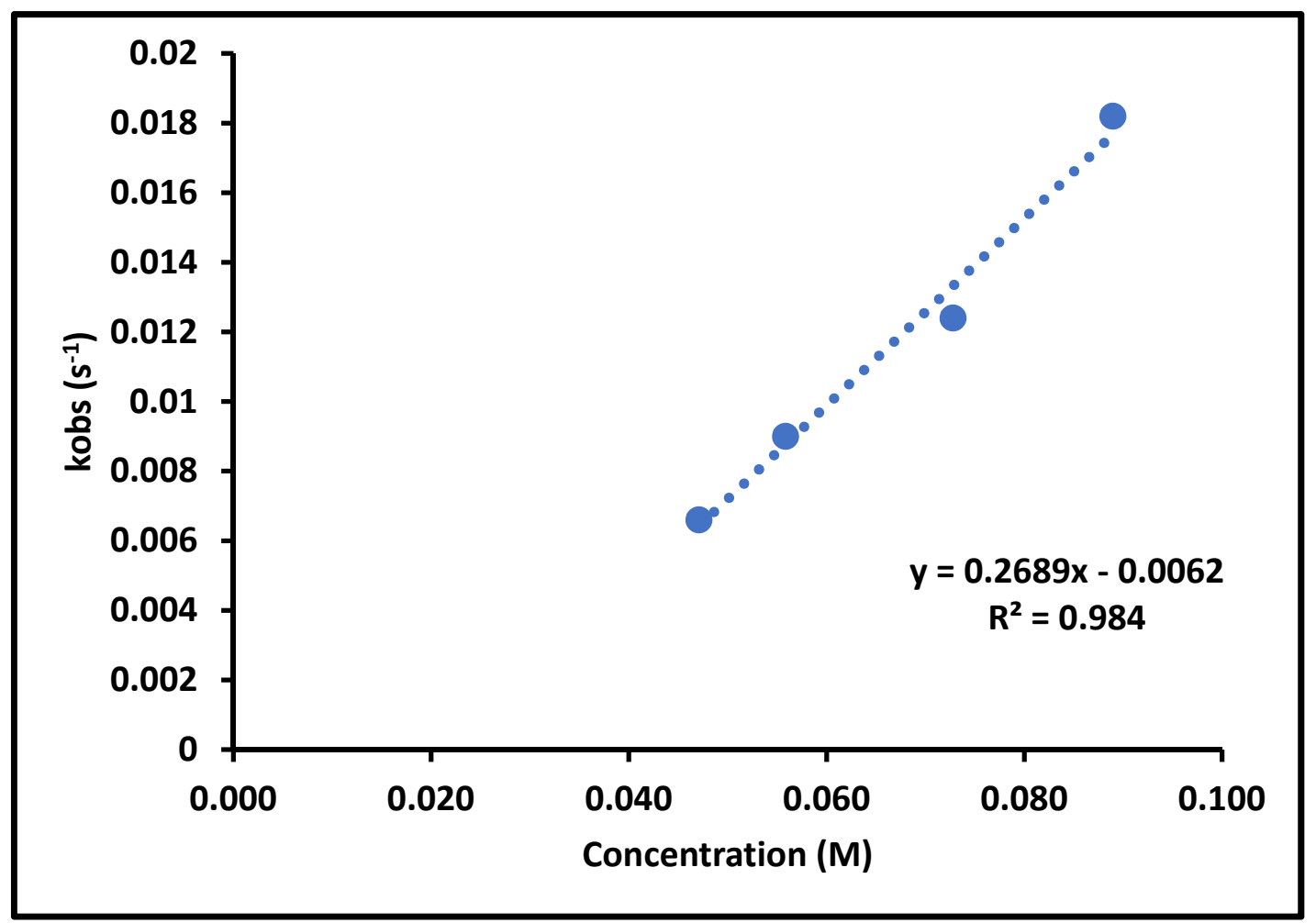

Figure S26. Plot of the pseudo first-order rate constant $\mathrm{k}_{\mathrm{obs}}\left(\mathrm{s}^{-1}\right) \mathrm{vs} .\left[\mathrm{P}\left(\mathrm{Ar}^{\mathrm{CF} 3}\right)_{3}\right](\mathrm{M})$ in the reaction with $\left[\mathrm{Me}_{2} \mathrm{NN}_{\mathrm{F} 6}\right] \mathrm{Cu}\left(\kappa^{2}-\mathrm{O}_{2} \mathrm{~N}\right)$ (initially $2.0 \mathrm{mM}$ ) in toluene at $-60{ }^{\circ} \mathrm{C}$.

\section{Eyring Analysis of 1 - 4 with $P\left(\mathrm{Ar}^{\mathrm{CF} 3}\right)_{3}$ :}

The following stock solutions were prepared and stored at $-40{ }^{\circ} \mathrm{C}$ between experiments: $2.0 \mathrm{mM}$ 1 - 4 in toluene, $0.8 \mathrm{M} \mathrm{P}\left(\mathrm{Ar}^{\mathrm{CF} 3}\right)_{3}$ in toluene. Reactions were conducted in a UV-Vis cuvette: 2 $\mathrm{mL}$ of the copper solution was transferred to a cuvette inside the glove box and sealed with a septum which maintained a steady green color that varied slightly with the different complexes. $0.1 \mathrm{~mL}$ (20 eq.) of the phosphine solution was drawn into a syringe inside the glove box as well. The cuvette was placed in the UV-vis equipped with the cryostat set to maintain the temperature. The solution was allowed to stir for $\sim 10$ min to allow the temperature to be uniform. After $\sim 30 \mathrm{~s}$ collection the phosphine was injected. The drop of the peak at $\sim 600 \mathrm{~nm}$ was followed after the injection of the phosphine solution. The final color of the solution was yellow. For $\mathbf{1}$ the temperatures used were $-60{ }^{\circ} \mathrm{C},-50{ }^{\circ} \mathrm{C},-40{ }^{\circ} \mathrm{C}$ and $-30{ }^{\circ} \mathrm{C}$. For 2 the temperatures used were $-70{ }^{\circ} \mathrm{C},-60{ }^{\circ} \mathrm{C},-50{ }^{\circ} \mathrm{C}$ and $-40{ }^{\circ} \mathrm{C}$. For 3 the temperatures were $10{ }^{\circ} \mathrm{C}, 20{ }^{\circ} \mathrm{C}, 30{ }^{\circ} \mathrm{C}$ and, $40{ }^{\circ} \mathrm{C}$. For 4 the temperatures were $15^{\circ} \mathrm{C}, 25^{\circ} \mathrm{C}, 35^{\circ} \mathrm{C}$, and $45^{\circ} \mathrm{C}$. Plotting the $\ln (\mathrm{k} / \mathrm{T})$ as function of 1/T according to the Eyring equation yielded activation enthalpy and activation entropy. 


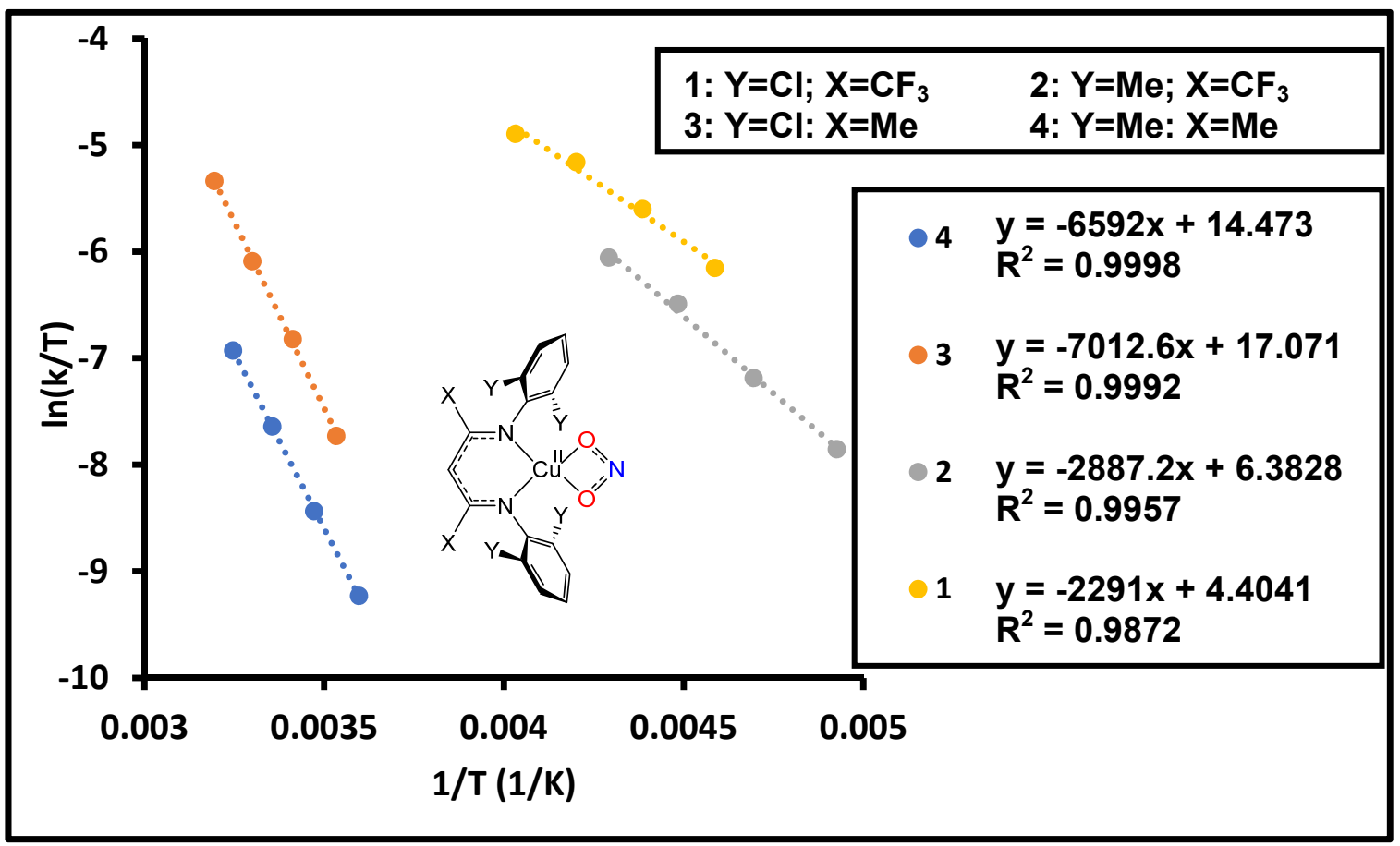

Figure S27. Eyring plot of $\ln (\mathrm{k} / \mathrm{T})$ vs. $1 / \mathrm{T}$ for the reaction of $1-4$ with $20 \mathrm{eq}$ $\mathrm{P}\left(\mathrm{Ar}^{\mathrm{CF} 3}\right)_{3}$ in toluene using true second order rate constants.

\section{Calculation of the Activation Parameters:}

The Eyring plot for each compound allows for the use of the Eyring equation:

$$
\ln \frac{k}{T}=\frac{-\Delta H^{\ddagger}}{R} \cdot \frac{1}{T}+\ln \frac{k_{B}}{h}+\frac{\Delta S}{R}
$$

to calculate the activation parameters, where $\mathrm{k}$ is the rate constant $\left(\mathrm{M}^{-1} \mathrm{~s}^{-1}\right), \mathrm{T}$ is the temperature $(\mathrm{K}), \Delta \mathrm{H}^{*}$ is the enthalpy of activation $(\mathrm{J} / \mathrm{mol}), \mathrm{R}$ is the gas constant $(\mathrm{J} / \mathrm{K} \cdot \mathrm{mol}), \mathrm{k}_{\mathrm{B}}$ is the Boltzmann constant $(\mathrm{J} / \mathrm{K}), \mathrm{h}$ is the Planck constant $(\mathrm{J} \bullet \mathrm{s})$, and $\Delta \mathrm{S}^{\ddagger}$ is the entropy of activation $(\mathrm{J} / \mathrm{mol} \cdot \mathrm{K})$. The equation of the line from the Eyring plot fits the form of the equation such that the slope of the line is equal to $-\Delta H^{\ddagger} / \mathrm{R}$ and the intercept of the line is equal to $\Delta \mathrm{S}^{\ddagger} / \mathrm{R}-\ln \frac{k B}{h}$. The values for $\Delta \mathrm{H}^{*}$ and $\Delta \mathrm{S}^{*}$ were then converted to $\mathrm{kcal} / \mathrm{mol}$ and cal $/ \mathrm{mol} \cdot \mathrm{K}$ respectively. To calculate the Gibbs free energy of activation $\left(-\Delta \mathrm{G}^{\dot{\$}}\right)$ at $298 \mathrm{~K}$ the equation:

$$
\Delta \boldsymbol{G}^{\ddagger}=\Delta \boldsymbol{H}^{\ddagger}-\boldsymbol{T} \Delta \boldsymbol{S}^{\ddagger}
$$

was used with $\mathrm{T}=298 \mathrm{~K}$. The standard error in the slope and intercept were calculated using the Microsoft Excel linest function and carried through the calculations to arrive at the errors in the activation parameters. 
Table S2. Activation Parameters for the Reaction of $1-4$ with $\mathrm{P}\left(\mathrm{Ar}^{\mathrm{CF} 3}\right)_{3}$.

\begin{tabular}{|c|c|c|c|c|}
\hline Copper Complex & $\begin{array}{c}\text { Reduction } \\
\text { Potential (V } \\
\text { v. NHE) in } \\
\text { THF }\end{array}$ & $\begin{array}{c}\Delta \mathbf{H}^{\ddagger} \\
(\mathrm{kcal} / \mathrm{mol})\end{array}$ & $\begin{array}{c}\Delta S^{\dagger} \\
\left(\mathrm{cal} / \mathrm{mol}^{*} \mathbf{K}\right)\end{array}$ & $\begin{array}{l}\Delta \mathrm{G}^{\ddagger} 298 \mathrm{~K} \\
(\mathrm{kcal} / \mathrm{mol})\end{array}$ \\
\hline$\left[\mathrm{Cl}_{2} \mathrm{NN}_{\mathrm{F} 6}\right] \mathrm{Cu}\left(\kappa^{2}-\mathrm{O}_{2} \mathrm{~N}\right)(1)$ & $0.331^{1}$ & $4.6 \pm 0.72$ & $-38.5 \pm 3.09$ & $16.0 \pm 1.17$ \\
\hline$\left[\mathrm{Me}_{2} \mathrm{NN}_{\mathrm{F} 6}\right] \mathrm{Cu}\left(\kappa^{2}-\mathrm{O}_{2} \mathrm{~N}\right)(2)$ & 0.303 & $5.7 \pm 0.52$ & $-34.5 \pm 2.41$ & $16.0 \pm 0.89$ \\
\hline$\left[\mathrm{Cl}_{2} \mathrm{NN}\right] \mathrm{Cu}\left(\kappa^{2}-\mathrm{O}_{2} \mathrm{~N}\right)(3)$ & -0.021 & $13.9 \pm 0.54$ & $-13.3 \pm 1.80$ & $17.9 \pm 0.76$ \\
\hline$\left[\mathrm{Me}_{2} \mathrm{NN}\right] \mathrm{Cu}\left(\kappa^{2}-\mathrm{O}_{2} \mathrm{~N}\right)(4)$ & -0.113 & $13.1 \pm 0.23$ & $-18.5 \pm 0.80$ & $18.6 \pm 0.33$ \\
\hline
\end{tabular}

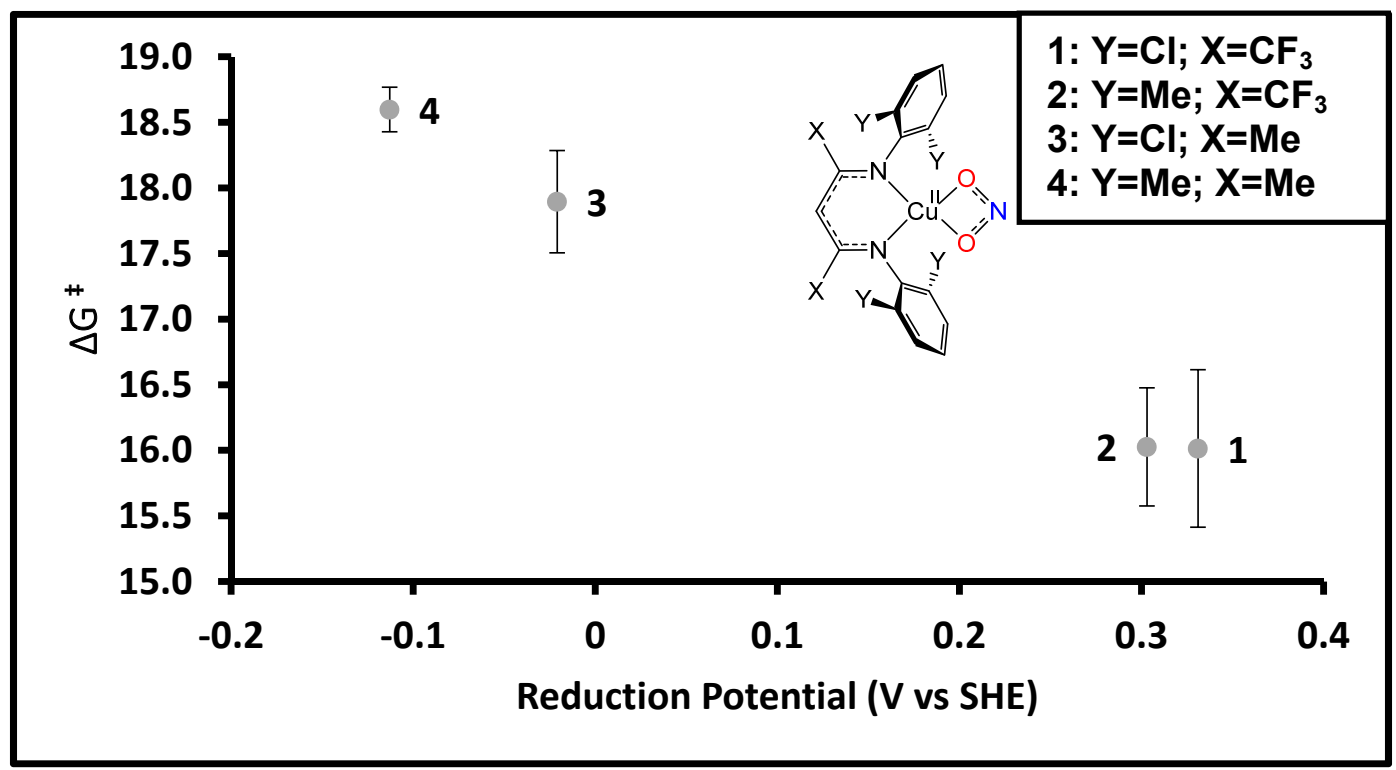

Figure S28. Trend in $\Delta \mathrm{G}^{\ddagger}(\mathrm{kcal} / \mathrm{mol})$ vs the reduction potential of the $[\mathrm{Cu}]\left(\kappa^{2}-\right.$ $\mathrm{O}_{2} \mathrm{~N}$ ) complexes as calculated from the Eyring analysis. 


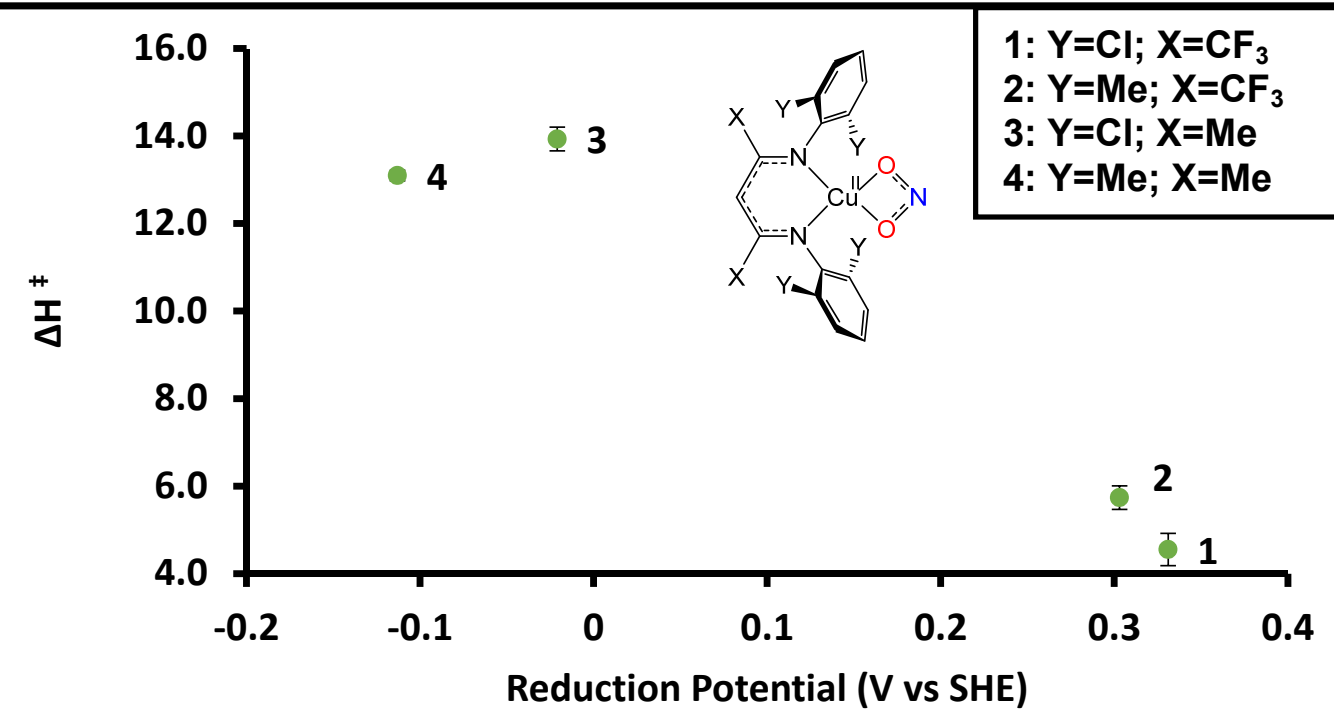

Figure S29. Trend in $\Delta \mathrm{H}^{\ddagger}(\mathrm{kcal} / \mathrm{mol})$ vs the reduction potential of the $[\mathrm{Cu}]\left(\kappa^{2}-\right.$ $\mathrm{O}_{2} \mathrm{~N}$ ) complexes as calculated from the Eyring analysis.

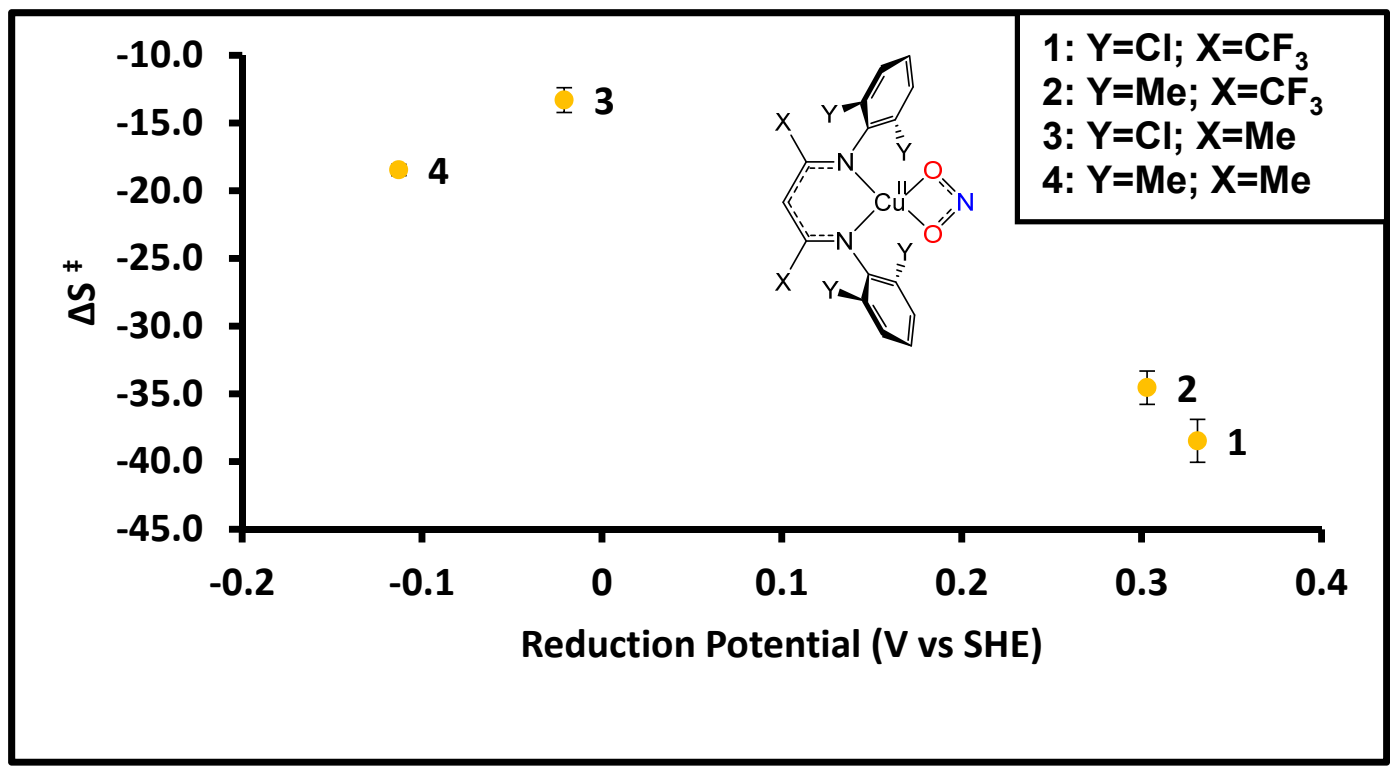

Figure S30. Trend in $\Delta \mathrm{S}^{\ddagger}(\mathrm{cal} / \mathrm{mol} \cdot \mathrm{K})$ vs the reduction potential of the $[\mathrm{Cu}]\left(\kappa^{2}-\mathrm{O}_{2} \mathrm{~N}\right)$ complexes as calculated from the Eyring analysis. 


\section{Hammett Plot for the reaction of $\left[\mathrm{Me}_{2} \mathrm{NN}\right] \mathrm{Cu}\left(\mathrm{k}^{2}-\mathrm{O}_{2} \mathrm{~N}\right)(4)$ with $\mathrm{P}\left(\mathrm{Ar}^{\mathrm{Z}}\right)_{3}(\mathrm{Z}=\mathrm{CF}$, $\mathrm{F}$, Cl, H, OMe):}

The following stock solutions were prepared and stored at $-40{ }^{\circ} \mathrm{C}$ between experiments: $2.0 \mathrm{mM}$ 4 in $\mathrm{PhF}, 0.80 \mathrm{M} \mathrm{P}\left(\mathrm{Ar}^{\mathrm{Z}}\right)_{3}$ in $\mathrm{PhF}$. Reactions were conducted in a UV-Vis cuvette: $2 \mathrm{~mL}$ of the copper solution was transferred to a cuvette inside the glove box and sealed with a septum which maintained a steady green color. 0.1 (20 eq.) of the phosphine solution was drawn into a syringe inside the glove box as well. The cuvette was placed in the UV-vis equipped with the cryostat set to maintain the temperature at $0^{\circ} \mathrm{C}$. The solution was allowed to stir for $\sim 10$ min to allow the temperature to be uniform. After $\sim 30 \mathrm{~s}$ collection the phosphine was injected. The drop of the peak at $600 \mathrm{~nm}$ was followed after the injection of the phosphine solution. The final color of the solution was yellow.

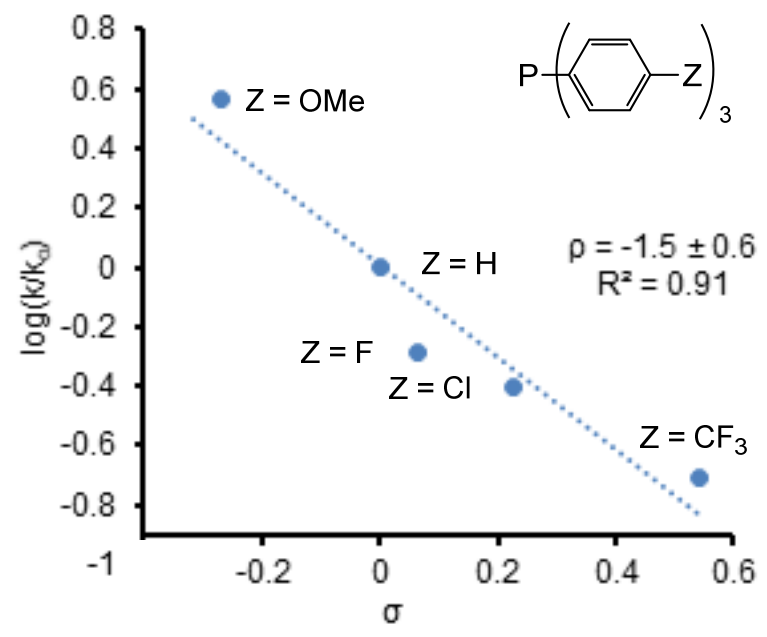

Figure S31. Hammett plot of $\log \left(\mathrm{k} / \mathrm{k}_{\mathrm{o}}\right)$ vs. $\sigma$ (para Hammett parameter) for the reaction of $\left[\mathrm{Me}_{2} \mathrm{NN}\right] \mathrm{Cu}\left(\kappa^{2}-\mathrm{O}_{2} \mathrm{~N}\right)$ with 20 equiv. $\mathrm{P}\left(\mathrm{Ar}^{\mathrm{Z}}\right)_{3}$ in $\mathrm{THF}$ at $0^{\circ} \mathrm{C}$ using true second order rate constants. 


\section{Crystallographic Details}

Single crystals of compounds 2 (CCDC 1875639), 4 (CCDC 2081113) and 5 (CCDC 1983021) were mounted under mineral oil on a Mitegen micro mount and immediately placed in a cold nitrogen stream at 100(2) K. Data for compounds 2 and 5 were collected on a Bruker D8 Quest equipped with a Photon100 CMOS detector and a MoImS source. Data for compound 4 was collected on a Bruker DUO equipped with an APEXII CCD detector and Mo fine focus sealed tube source. A hemisphere of data was collected $\left(0.5^{\circ} \omega\right.$-scans; monochromatic Mo K $\alpha$ radiation, $\lambda=0.7107 \AA$ ) and integrated with the Bruker SAINT program. Structure solutions were performed using the SHELXTL/PC suite. ${ }^{5}$ Intensities were corrected for Lorentz and polarization effects and an empirical absorption correction was applied using Blessing's method as incorporated into the program SADABS. ${ }^{6}$ Non-hydrogen atoms were refined with anisotropic thermal parameters and hydrogen atoms were included in idealized positions. Structures were rendered with Mercury using 50\% probability ellipsoids.

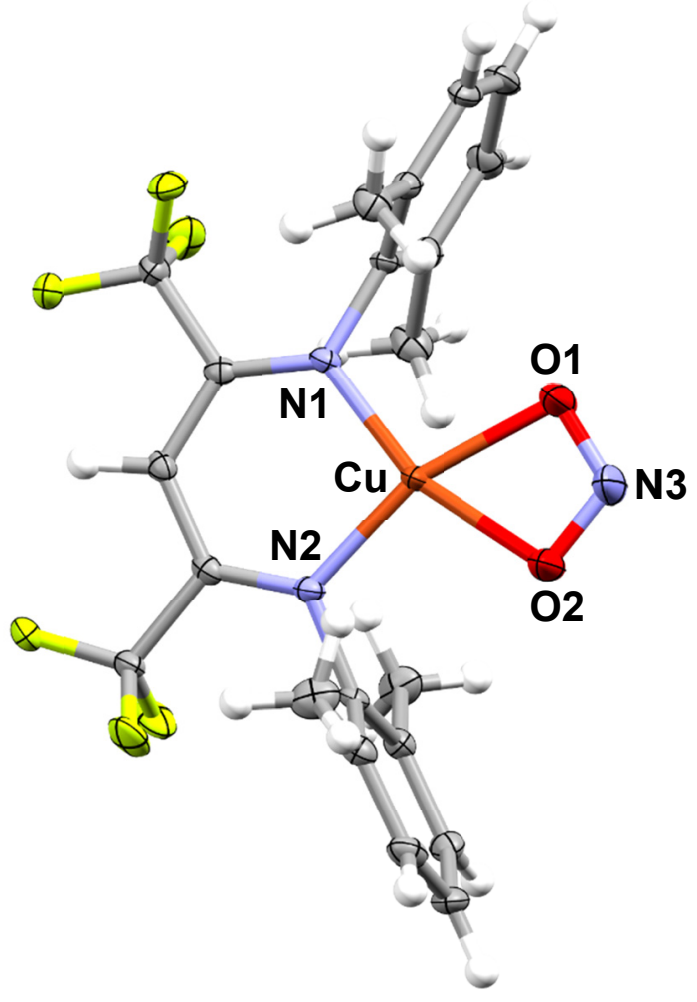

Figure S32. Molecular structure of $\left[\mathrm{Me}_{2} \mathrm{NN}_{\mathrm{F} 6}\right] \mathrm{Cu}\left(\kappa^{2}-\mathrm{O}_{2} \mathrm{~N}\right)$ (2) (CCDC 1875639). Thermal ellipsoid plots are shown at 50\% probability level. Selected bond distances $(\AA)$ and angles (deg): Cu1-N1 1.8987(17), Cu1-N2 1.9021(18), Cu1-O1 2.0127(19), Cu1-O2 2.0103(18), N3-O1 1.252(3), N3-O2 1.256(3), O1-Cu1-O2 61.51(7), O1-N3-O2 110.2(2). 


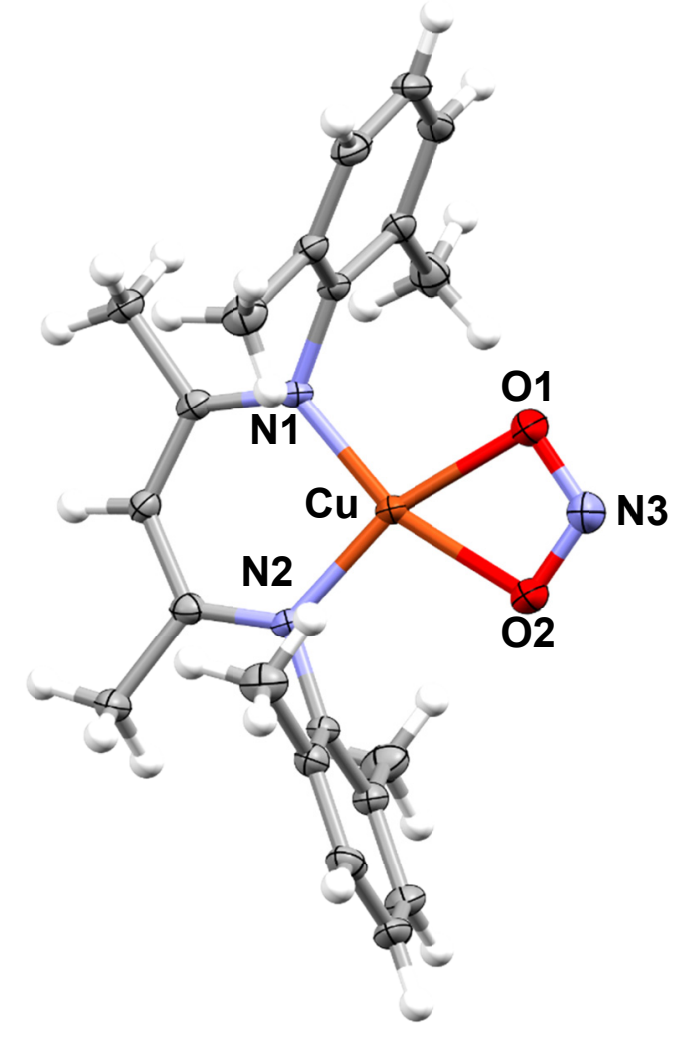

Figure S33. Molecular structure of $\left[\mathrm{Me}_{2} \mathrm{NN}\right] \mathrm{Cu}\left(\kappa^{2}-\mathrm{O}_{2} \mathrm{~N}\right)$ (4) (CCDC 2081113). Thermal ellipsoid plots are shown at 50\% probability level. Selected bond distances $(\AA)$ and angles (deg): N1-Cu 1.894(1); N2-Cu 1.890(2); Cu-O1 2.031(2); Cu-O2 2.031(1); O2-N3 1.264(3); O1-N3 1.261(2); N1-Cu-N2 96.93(7); O1-Cu-O2 61.37(6); O2-N3-O1 110.4(2); Cu-O2-N3 94.1(1); Cu-O1-N3 94.2(1). 


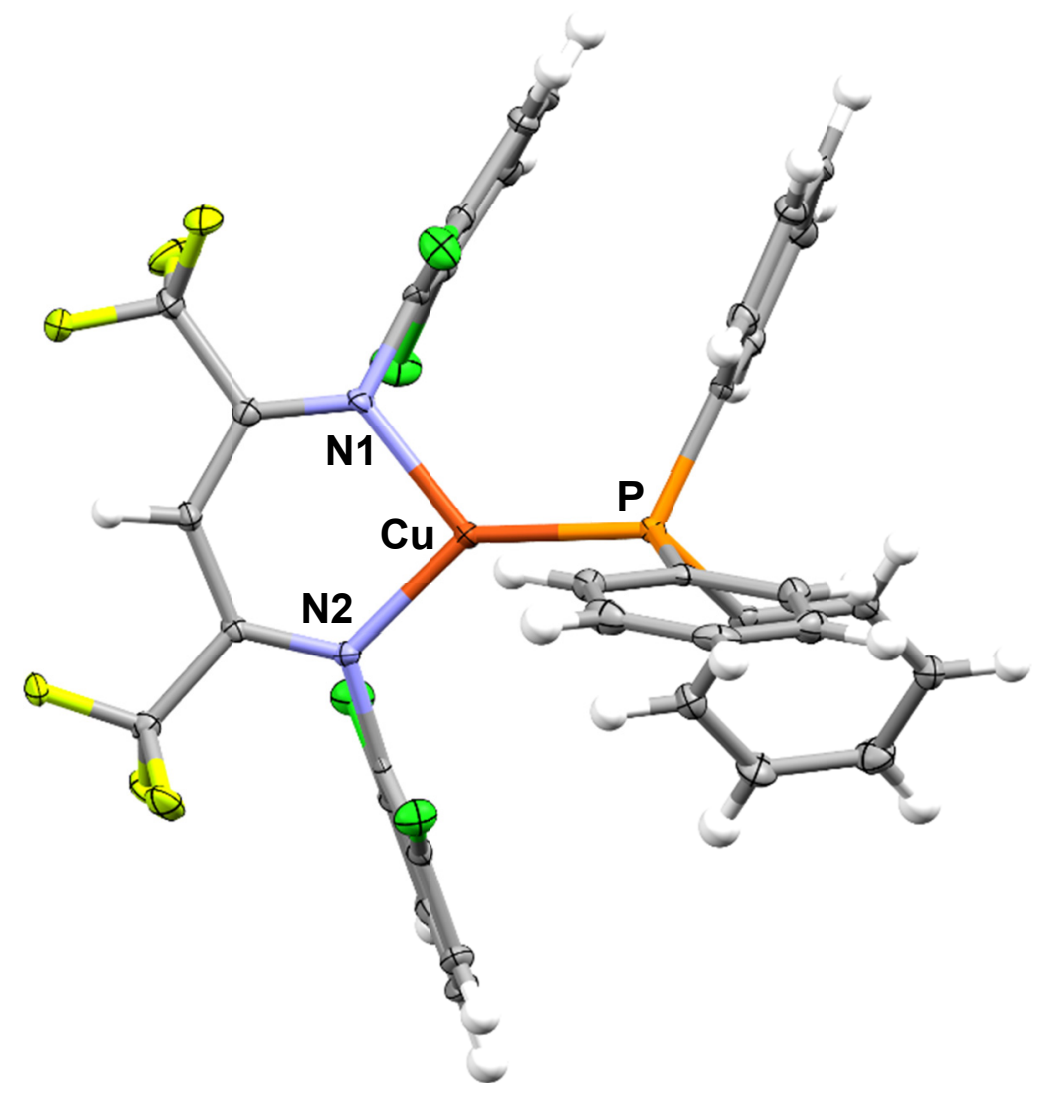

Figure S34. Molecular structure of $\left[\mathrm{Cl}_{2} \mathrm{NN}_{\mathrm{F} 6}\right] \mathrm{Cu}\left(\mathrm{PPh}_{3}\right)(5)(\mathrm{CCDC} 1983021)$. The thermal ellipsoid plots are drawn at 50\% probability level. Selected bond distances $(\AA)$ and angles $\left(^{\circ}\right)$ : N1$\mathrm{Cu}$ 1.978(2), N2-Cu 1.964(2), Cu-P 2.1811(7); N1-Cu-N2 95.99(8), N1-Cu-P 126.79(6), N2-Cu-P 136.85(6). 


\section{Computational Study}

Gaussian $16^{7}$ was used to optimize the structures, calculate single point geometries, and also find the vibrational frequencies and reaction free energies. Visualization and structural analyses were done using Chemcraft 1.8 and CCDC-Mercury. ${ }^{8}$ Seven complexes were studied for the ligand $\left[\mathrm{Me}_{2} \mathrm{NN}\right]: \quad\left[\mathrm{Me}_{2} \mathrm{NN}\right] \mathrm{Cu}^{\mathrm{II}}\left(\kappa^{2}-\mathrm{O}_{2} \mathrm{~N}\right), \quad\left[\mathrm{Me}_{2} \mathrm{NN}\right] \mathrm{Cu}^{\mathrm{II}}\left(\kappa^{1}-\mathrm{NO}_{2}\right), \quad\left\{\left[\mathrm{Me}_{2} \mathrm{NN}\right] \mathrm{Cu}^{\mathrm{I}}\left(\kappa^{1}-\mathrm{NO}_{2}\right)\right\}^{-}$, $\left[\mathrm{Me}_{2} \mathrm{NN}\right] \mathrm{Cu}-\mathrm{NO},\left[\mathrm{Me}_{2} \mathrm{NN}\right] \mathrm{Cu}-\mathrm{ON},\left[\mathrm{Me}_{2} \mathrm{NN}\right] \mathrm{Cu}^{\mathrm{I}}-\mathrm{P}\left(\mathrm{Ar}^{\mathrm{CF} 3}\right)_{3}$, and $\left[\mathrm{Me}_{2} \mathrm{NN}\right] \mathrm{Cu}-\mathrm{SMe}_{2}$ as well as six transition states $\left[\mathrm{Me}_{2} \mathrm{NN}\right] \mathrm{Cu}\left(\kappa^{2}-\mathrm{O}_{2} \mathrm{~N}\right)-\mathrm{P}\left(\mathrm{Ar}^{\mathrm{CF} 3}\right)_{3}, \quad\left[\mathrm{Me}_{2} \mathrm{NN}\right] \mathrm{Cu}\left(\kappa^{1}-\mathrm{O}_{2} \mathrm{~N}\right)-\mathrm{P}\left(\mathrm{Ar}^{\mathrm{CF} 3}\right)_{3}$, $\left[\mathrm{Me}_{2} \mathrm{NN}\right] \mathrm{Cu}\left(\kappa^{1}-\mathrm{NO}_{2}\right)-\mathrm{P}\left(\mathrm{Ar}^{\mathrm{CF} 3}\right)_{3}, \quad\left[\mathrm{Me}_{2} \mathrm{NN}\right] \mathrm{Cu}\left(\kappa^{1}-\mathrm{NO}_{2}-90^{\circ}\right)-\mathrm{P}\left(\mathrm{Ar}^{\mathrm{CF} 3}\right)_{3}, \quad\left[\mathrm{Me}_{2} \mathrm{NN}\right] \mathrm{Cu}\left(\kappa^{1}-\mathrm{ONO}\right), \quad \mathrm{a}$ transition state for the isomerization from $[\mathrm{Cu}]\left(\kappa^{2}-\mathrm{O}_{2} \mathrm{~N}\right)$ to $[\mathrm{Cu}]\left(\kappa^{1}-\mathrm{NO}_{2}\right)$, and $\left[\mathrm{Me}_{2} \mathrm{NN}\right] \mathrm{Cu}\left(\kappa^{1}-\right.$ $\left.\mathrm{NO}_{2}\right)-\mathrm{SMe}_{2}$. For the ligands $\left[\mathrm{Cl}_{2} \mathrm{NN}_{\mathrm{F} 6}\right],\left[\mathrm{Me}_{2} \mathrm{NN}_{\mathrm{F} 6}\right]$ and $\left[\mathrm{Cl}_{2} \mathrm{NN}\right]$, the complexes $\left[\mathrm{Cu}^{\mathrm{II}}\right]\left(\kappa^{2}-\mathrm{O}_{2} \mathrm{~N}\right)$, $\left[\mathrm{Cu}^{\mathrm{II}}\right]\left(\kappa^{1}-\mathrm{NO}_{2}\right),[\mathrm{Cu}]-\mathrm{NO}$, and $\left[\mathrm{Cu}^{\mathrm{I}}\right]-\mathrm{SMe}_{2}$ were studied along with the transition states $[\mathrm{Cu}]-$ $\mathrm{ONO}$ and $[\mathrm{Cu}]\left(\kappa^{1}-\mathrm{NO}_{2}\right)-\mathrm{SMe}_{2}$. Each transition state exhibits a single imaginary frequency along the transformation in question and the lowest energy for OAT for complex $4,\left[\mathrm{Me}_{2} \mathrm{NN}\right] \mathrm{Cu}\left(\kappa^{1}-\right.$ $\left.\mathrm{NO}_{2}-90^{\circ}\right)-\mathrm{P}\left(\mathrm{Ar}^{\mathrm{CF}}\right)_{3}$, was confirmed by an IRC calculation, but did not converge on the Max Displacement convergence criteria with a calcall calculation. Five small molecules (NO, $\left.\mathrm{P}\left(\mathrm{Ar}^{\mathrm{CF} 3}\right)_{3}, \mathrm{OP}\left(\mathrm{Ar}^{\mathrm{CF} 3}\right)_{3}, \mathrm{SMe}_{2}, \mathrm{OSMe}_{2}\right)$ were also calculated to analyze the thermodynamics of the reactions between the complexes, and $\mathrm{P}\left(\mathrm{Ar}^{\mathrm{CF}}\right)_{3}, \mathrm{OP}\left(\mathrm{Ar}^{\mathrm{CF} 3}\right)_{3}$ also did not meet the Max Displacement or RMS Displacement convergence criteria with calcall calculations. It is likely that the aryl groups are able to occupy multiple equivalent energy conformations which leads to a flattening of the energy surfaces of these structures around the minima, which leads to difficulty meeting these convergence criteria but indicates that the energy of the true stable point is highly unlikely to be significantly different. The BP $86^{9}$ functional in conjunction with the 6$311+\mathrm{G}(\mathrm{d})$ basis set $\left(5 \mathrm{~d} 7 \mathrm{f}\right.$ spherical harmonics) ${ }^{10-13}$ was used for optimization of all geometries. At the BP86/6-311+G(d) stationary points, single point energies were calculated using BP86 with the $6-311++\mathrm{G}(\mathrm{d}, \mathrm{p})^{14-21}$ basis set, in toluene using the implicit $\mathrm{SMD}^{22}$ solvent model and adding dispersion corrections with the keyword, empirical dispersion $=$ GD3BJ. ${ }^{23}$ 
Table S3. Gibbs free energies (BP86/6-311+G(d)/gas//BP86+GD3BJ/6 $311++\mathrm{G}(\mathrm{d}, \mathrm{p}) / \mathrm{SMDtoluene})$ at $298.15 \mathrm{~K}$ of the computed molecules. $[\mathrm{Cu}]=\left[\mathrm{Me}_{2} \mathrm{NN}\right] \mathrm{Cu}$ fragment.

\begin{tabular}{|c|c|c|c|}
\hline Compound & Charge & Multiplicity & $\begin{array}{c}\text { Gibbs Free Energy } \\
\text { (Hartrees) }\end{array}$ \\
\hline $\mathrm{NO}$ & 0 & 2 & -129.9517649 \\
\hline $\mathrm{P}\left(\mathrm{Ar}^{\mathrm{CF} 3}\right)_{3}$ & 0 & 1 & -2047.864418 \\
\hline $\mathrm{OP}\left(\mathrm{Ar}^{\mathrm{CF} 3}\right)_{3}$ & 0 & 1 & -2123.142023 \\
\hline $\mathrm{SMe}_{2}$ & 0 & 1 & -478.0515799 \\
\hline $\mathrm{OSMe}_{2}$ & 0 & 1 & -553.2667054 \\
\hline$\left[\mathrm{Cu}^{\mathrm{II}}\right]-\mathrm{O}_{2} \mathrm{~N}$ & 0 & 2 & -2770.811019 \\
\hline$\left[\mathrm{Cu}^{\mathrm{II}}\right]-\mathrm{NO}_{2}$ & 0 & 2 & -2770.809528 \\
\hline$\left[\mathrm{Cu}^{\mathrm{I}}\right]-\mathrm{NO}_{2}$ & -1 & 1 & -2770.940493 \\
\hline$\left[\mathrm{Cu}^{\mathrm{II}}\right]-\mathrm{ONO}(\mathrm{TS})$ & 0 & 2 & -2770.798131 \\
\hline$[\mathrm{Cu}]-\mathrm{NO}$ & 0 & 2 & -2695.576779 \\
\hline$[\mathrm{Cu}]-\mathrm{ON}$ & 0 & 2 & -2695.544024 \\
\hline$\left[\mathrm{Cu}^{1}\right]-\mathrm{P}\left(\mathrm{Ar}^{\mathrm{CF} 3}\right)_{3}$ & 0 & 1 & -4613.500029 \\
\hline$\left[\mathrm{Cu}^{\mathrm{I}}\right]-\mathrm{SMe}_{2}$ & 0 & 1 & -3043.664771 \\
\hline $\mathrm{TS}_{1}\left[\mathrm{Cu}^{\mathrm{II}}\right]-\mathrm{NO}_{2}-90^{\circ}-\mathrm{P}\left(\mathrm{Ar}^{\mathrm{CF} 3}\right)_{3}$ & 0 & 2 & -4818.645077 \\
\hline $\mathrm{TS}_{2}\left[\mathrm{Cu}^{\mathrm{II}}\right]-\mathrm{NO}_{2}-\mathrm{P}\left(\mathrm{Ar}^{\mathrm{CF} 3}\right)_{3}$ & 0 & 2 & -4818.634946 \\
\hline $\mathrm{TS}_{3}\left[\mathrm{Cu}^{\mathrm{II}}\right]-\mathrm{ONO}-\mathrm{P}\left(\mathrm{Ar}^{\mathrm{CF} 3}\right)_{3}$ & 0 & 2 & -4818.631068 \\
\hline $\mathrm{TS}_{4}\left[\mathrm{Cu}^{\mathrm{Il}}\right]-\mathrm{O}_{2} \mathrm{~N}-\mathrm{P}\left(\mathrm{Ar}^{\mathrm{CF} 3}\right)_{3}$ & 0 & 2 & -4818.625861 \\
\hline$\left[\mathrm{Cu}^{\mathrm{Il}}\right]-\mathrm{NO}_{2}-\mathrm{SMe}_{2}$ & 0 & 2 & -3248.795438 \\
\hline
\end{tabular}


Table S4. Gibbs free energies (BP86/6-311+G(d)/gas//BP86+GD3BJ/6 $311++\mathrm{G}(\mathrm{d}, \mathrm{p}) / \mathrm{SMDtoluene})$ at $298.15 \mathrm{~K}$ of the computed molecules. $[\mathrm{Cu}]=\left[\mathrm{Cl}_{2} \mathrm{NN}\right] \mathrm{Cu}$ fragment.

\begin{tabular}{|l|c|c|c|}
\hline \multicolumn{1}{|c|}{ Compound } & Charge & Multiplicity & $\begin{array}{c}\text { Gibbs Free Energy } \\
\text { (Hartrees) }\end{array}$ \\
\hline$\left[\mathrm{Cu}^{\mathrm{Il}}\right]-\mathrm{O}_{2} \mathrm{~N}$ & 0 & 2 & -4452.270227 \\
\hline$[\mathrm{Cu}]-\mathrm{NO}_{2}$ & 0 & 2 & -4452.268823 \\
\hline$[\mathrm{Cu}]-\mathrm{ONO}(\mathrm{TS})$ & 0 & 2 & -4452.25544 \\
\hline$[\mathrm{Cu}]-\mathrm{NO}$ & 0 & 2 & -4377.038639 \\
\hline$[\mathrm{Cu}]-\mathrm{SMe}_{2}$ & 0 & 1 & -4725.130883 \\
\hline$\left[\mathrm{Cu}^{\mathrm{II}}\right]-\mathrm{NO}_{2}-\mathrm{SMe}_{2}$ & 0 & 2 & -4930.259068 \\
\hline
\end{tabular}

Table S5. Gibbs free energies (BP86/6-311+G(d)/gas//BP86+GD3BJ/6 $311++\mathrm{G}(\mathrm{d}, \mathrm{p}) / \mathrm{SMDtoluene})$ at $298.15 \mathrm{~K}$ of the computed molecules. $[\mathrm{Cu}]=\left[\mathrm{Me}_{2} \mathrm{NN}_{\mathrm{F} 6}\right] \mathrm{Cu}$ fragment.

\begin{tabular}{|l|c|c|c|}
\hline \multicolumn{1}{|c|}{ Compound } & Charge & Multiplicity & $\begin{array}{c}\text { Gibbs Free Energy } \\
\text { (Hartrees) }\end{array}$ \\
\hline$\left[\mathrm{Cu}^{\mathrm{Il}}\right]-\mathrm{O}_{2} \mathrm{~N}$ & 0 & 2 & -3366.493183 \\
\hline$\left[\mathrm{Cu}{ }^{\mathrm{II}}\right]-\mathrm{NO}_{2}$ & 0 & 2 & -3366.491698 \\
\hline$[\mathrm{Cu}]-\mathrm{ONO}(\mathrm{TS})$ & 0 & 2 & -3366.480306 \\
\hline$[\mathrm{Cu}]-\mathrm{NO}$ & 0 & 2 & -3291.261191 \\
\hline$[\mathrm{Cu}]-\mathrm{SMe}_{2}$ & 0 & 1 & -3639.357387 \\
\hline$\left[\mathrm{Cu}^{\mathrm{II}}\right]-\mathrm{NO}_{2}-\mathrm{SMe}_{2}$ & 0 & 2 & -3844.485937 \\
\hline
\end{tabular}

Table S6. Gibbs free energies (BP86/6-311+G(d)/gas//BP86+GD3BJ/6 $311++\mathrm{G}(\mathrm{d}, \mathrm{p}) / \mathrm{SMDtoluene})$ at $298.15 \mathrm{~K}$ of the computed molecules. $[\mathrm{Cu}]=\left[\mathrm{Cl}_{2} \mathrm{NN}_{\mathrm{F} 6}\right] \mathrm{Cu}$ fragment.

\begin{tabular}{|l|c|c|c|}
\hline \multicolumn{1}{|c|}{ Compound } & Charge & Multiplicity & $\begin{array}{c}\text { Gibbs Free Energy } \\
\text { (Hartrees) }\end{array}$ \\
\hline$\left[\mathrm{Cu}^{\mathrm{II}}\right]-\mathrm{O}_{2} \mathrm{~N}$ & 0 & 2 & -5047.94652 \\
\hline$\left[\mathrm{Cu}^{\mathrm{II}}\right]-\mathrm{NO}_{2}$ & 0 & 2 & -5047.945673 \\
\hline$\left[\mathrm{Cu}^{\mathrm{II}}\right]-\mathrm{ONO}(\mathrm{TS})$ & 0 & 2 & -5047.932335 \\
\hline$[\mathrm{Cu}]-\mathrm{NO}$ & 0 & 2 & -4972.717738 \\
\hline$\left[\mathrm{Cu}^{1}\right]-\mathrm{SMe}_{2}$ & 0 & 1 & -5320.817783 \\
\hline$\left[\mathrm{Cu}^{\mathrm{II}}\right]-\mathrm{NO}_{2}-\mathrm{SMe}_{2}$ & 0 & 2 & -5525.944646 \\
\hline
\end{tabular}




\section{Nitrite Isomerization}

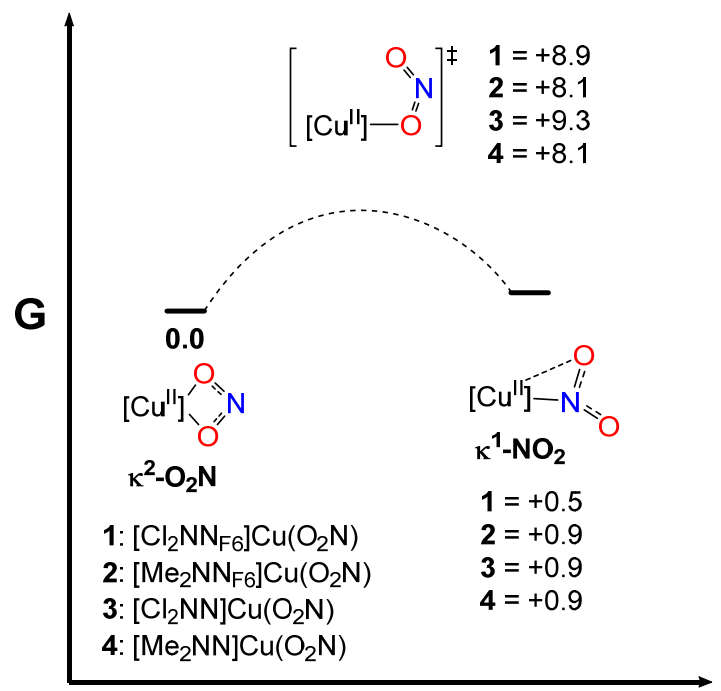

Figure S35. Proposed mechanism for the nitrite isomerization of 1-4. Calculated Gibbs free energies in $\mathrm{kcal} / \mathrm{mol}$ at $298.15 \mathrm{~K}$.

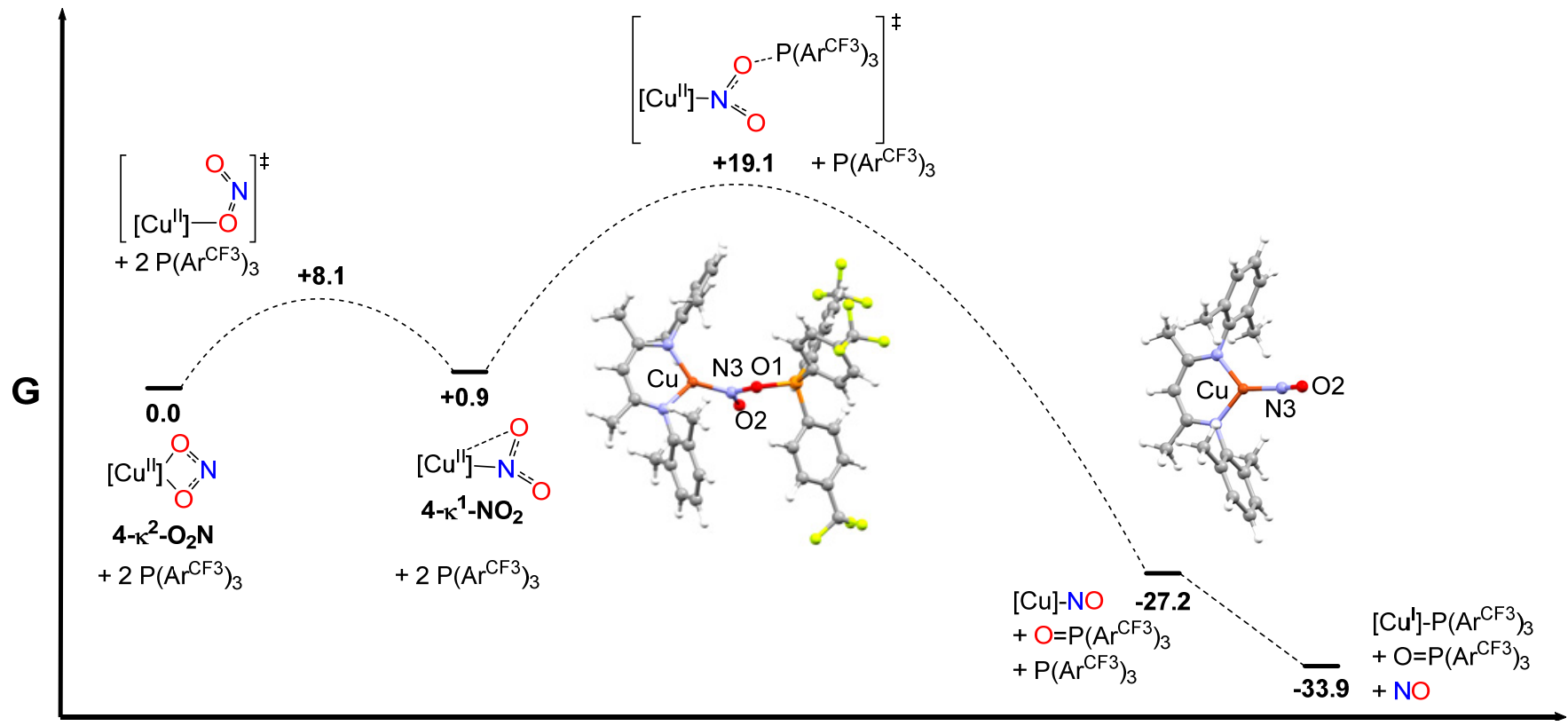

Figure S36. Proposed mechanism for the overall reduction of 4 with 2 equiv. $\mathrm{P}\left(\mathrm{Ar}^{\mathrm{CF} 3}\right)_{3}$. Calculated Gibbs free energies in $\mathrm{kcal} / \mathrm{mol}$ at $298.15 \mathrm{~K}$. 


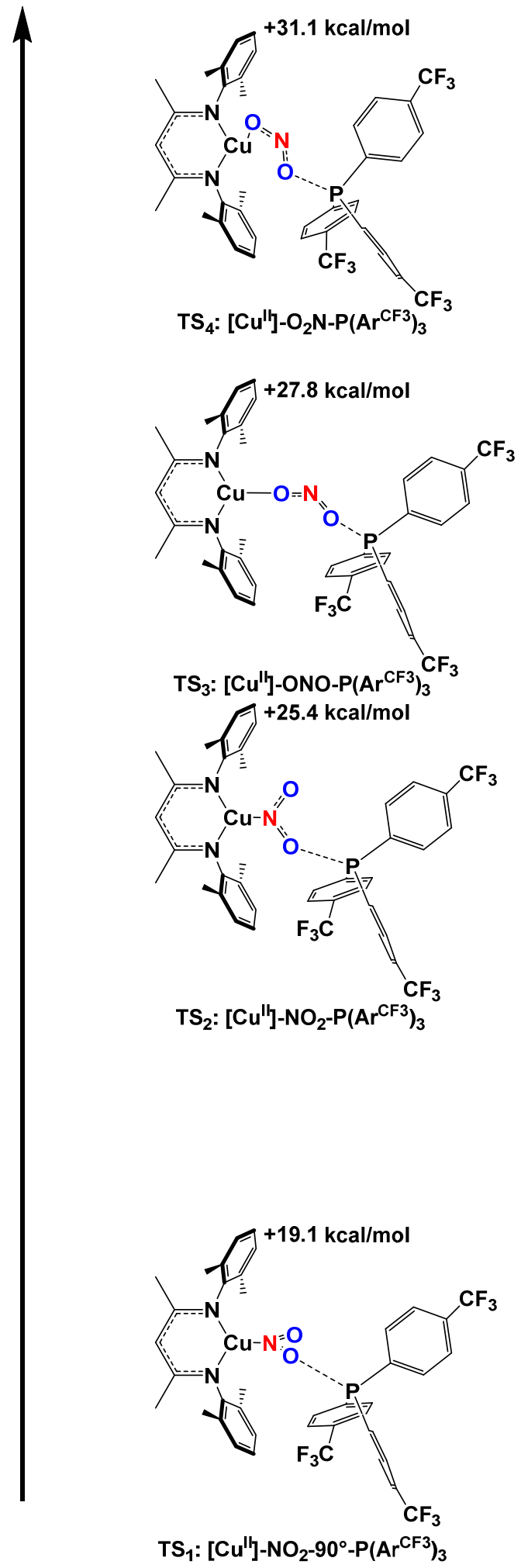

Figure S37. Gibbs Free Energy of four optimized transition states of oxygen atom transfer relative to starting materials. The lowest energy transition state was confirmed by an IRC calculation. 


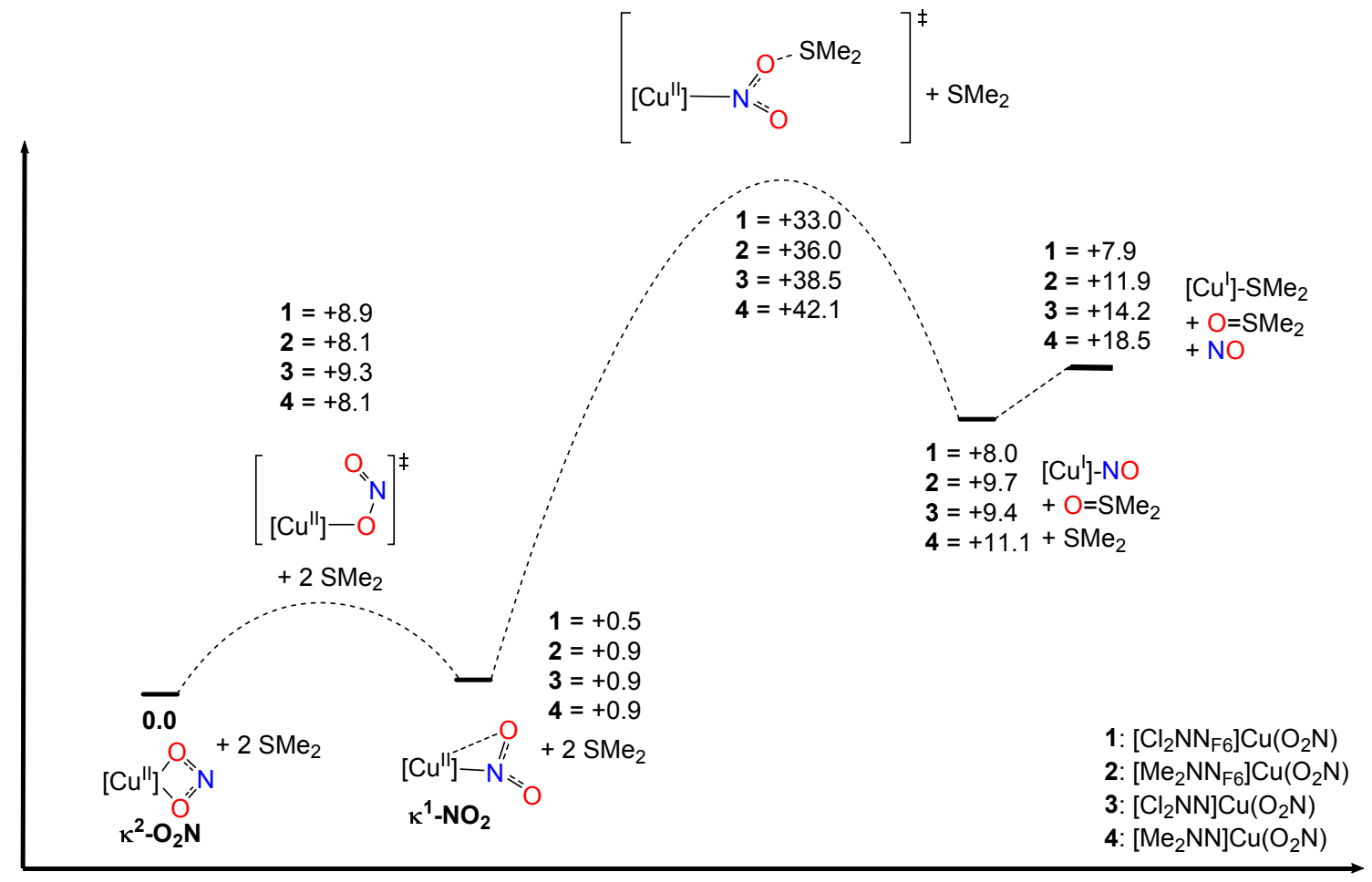

Figure S38. Proposed mechanism for the overall reduction of 1-4 with 2 equiv. $\mathrm{SMe}_{2}$. Calculated Gibbs free energies in $\mathrm{kcal} / \mathrm{mol}$ at $298.15 \mathrm{~K}$.

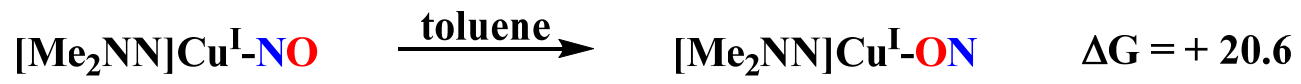

Scheme S3. Copper nitrosyl to copper isonitrosyl reorganization energy in toluene with ligand from 4. Calculated Gibbs free energy in kcal/mol at $298.15 \mathrm{~K}$. 


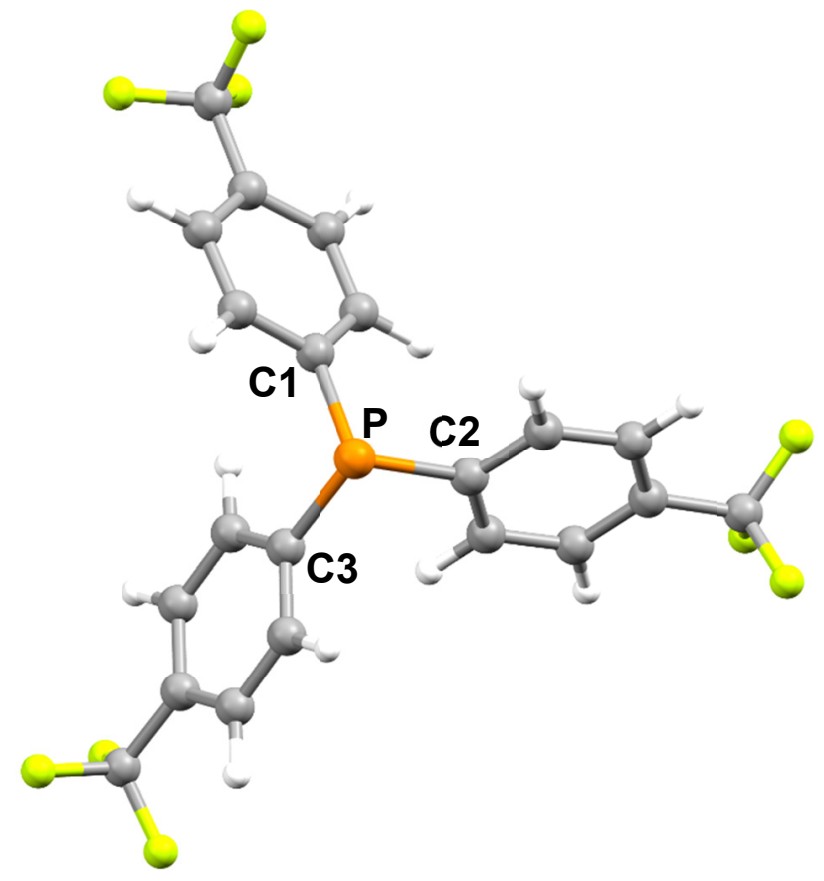

Figure S39. Geometry optimized structure of $\mathrm{P}\left(\mathrm{Ar}^{\mathrm{CF} 3}\right)_{3}$ at $\mathrm{BP} 86 / 6-311+\mathrm{G}(\mathrm{d})$ level of theory with charge $=0$, multiplicity $=1$. Selected calculated bond distances $(\AA)$ and angles $\left({ }^{\circ}\right)$ : P-C1 1.858, P-C2 1.859, P-C3 1.858; C1-P-C2 102.02, C2-P-C3 102.03, C1-P-C3 102.02.

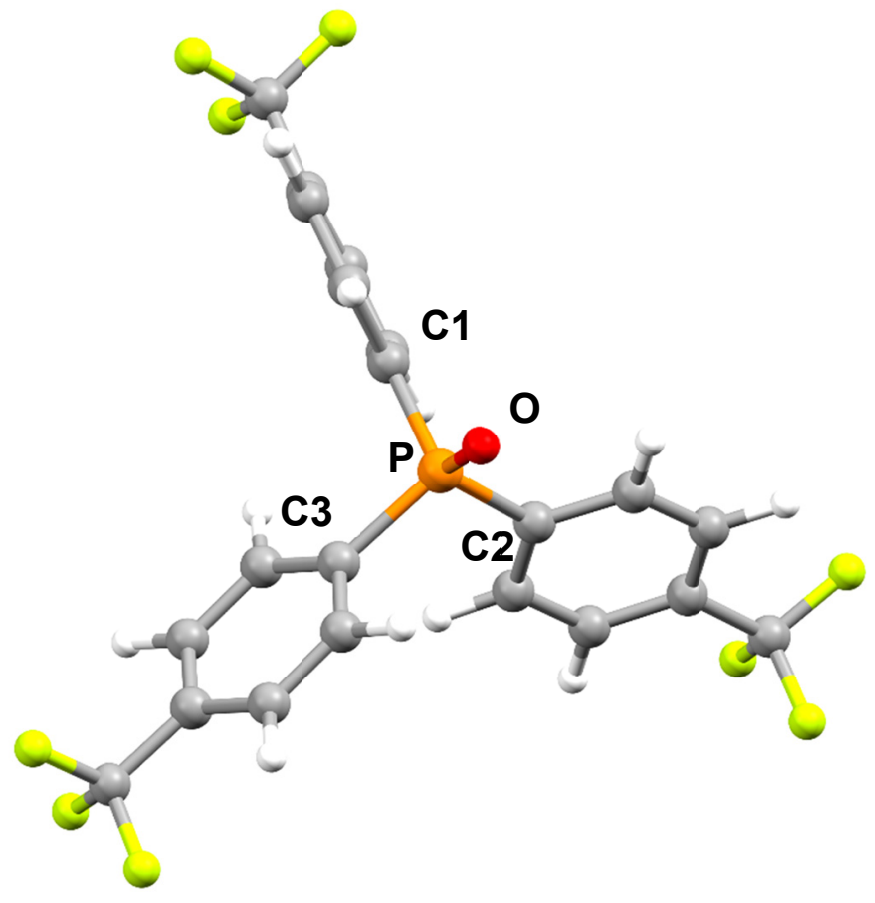

Figure S40. Geometry optimized structure of $\mathrm{OP}\left(\mathrm{Ar}^{\mathrm{CF} 3}\right)_{3}$ at $\mathrm{BP} 86 / 6-311+\mathrm{G}(\mathrm{d})$ level of theory with charge $=0$, multiplicity $=1$. Selected calculated bond distances $(\AA)$ and angles ${ }^{\circ}$ ): P-O 1.513 P-C1 1.842, P-C2 1.842, P-C3 1.842; C1-P-C2 105.93, C2-P-C3 105.92, C1P-C3 105.93, C1-P-O 112.81. 


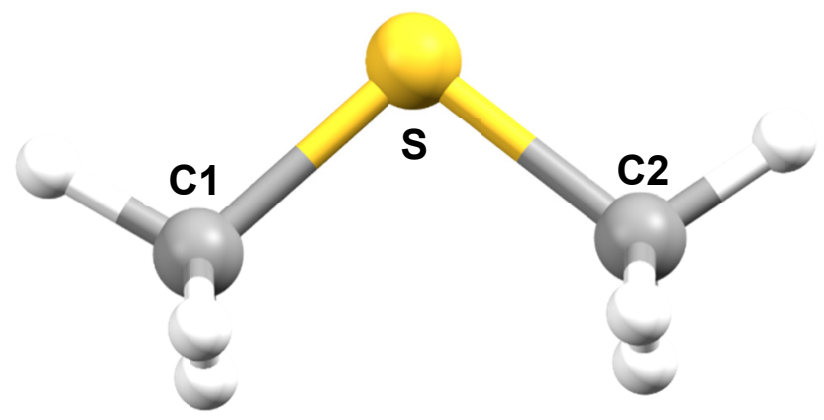

Figure S41. Geometry optimized structure of $\mathrm{SMe}_{2}$ at BP86/6-311+G(d) level of theory with charge $=0$, multiplicity $=1$. Selected calculated bond distances $(\AA)$ and angles $\left({ }^{\circ}\right)$ : S-C1 1.828, S-C2 1.828; C1-S-C2 99.32.

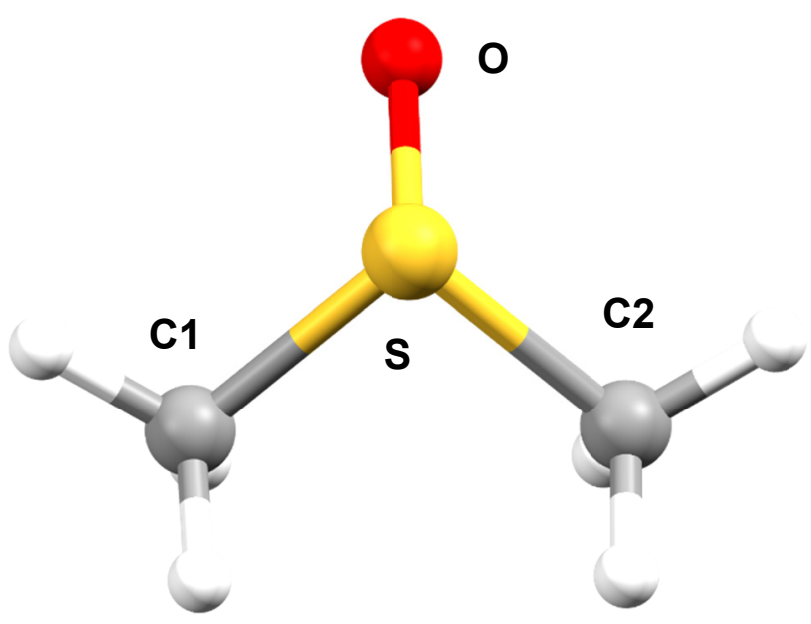

Figure S42. Geometry optimized structure of $\mathrm{OSMe}_{2}$ at $\mathrm{BP} 86 / 6-311+\mathrm{G}(\mathrm{d})$ level of theory with charge $=0$, multiplicity $=1$. Selected calculated bond distances $(\AA)$ and angles $\left({ }^{\circ}\right)$ : S-O 1.525 S-C1 1.851, S-C2 1.851; C1-S-C2 95.69, C1-S-O 107.15, C2-S-O 107.17. 


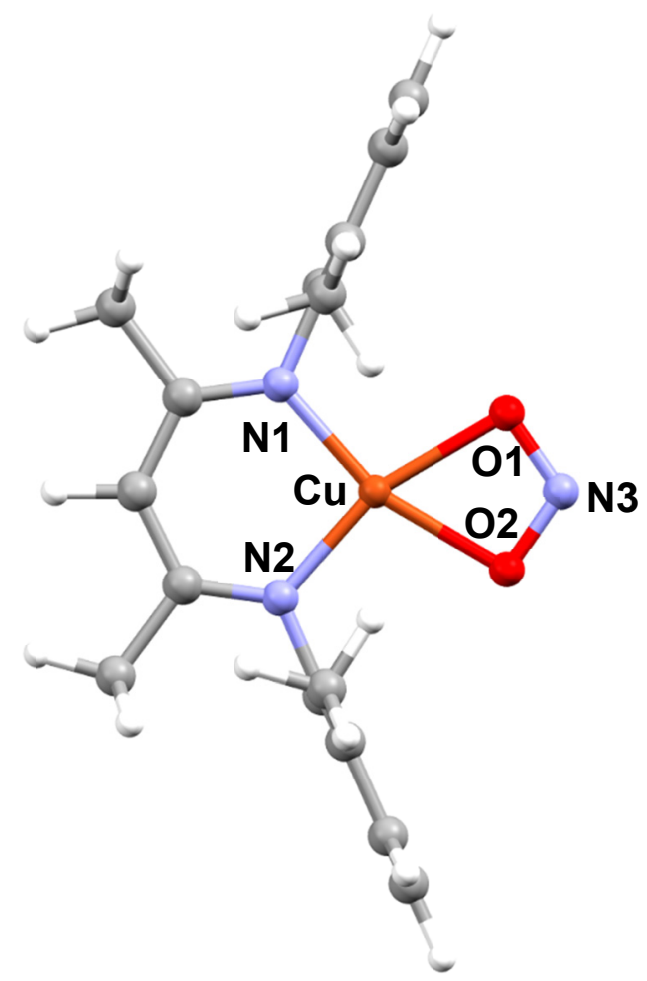

Figure S43. Geometry optimized structure of $\left[\mathrm{Me}_{2} \mathrm{NN}\right] \mathrm{Cu}^{\mathrm{II}}\left(\kappa^{2}-\mathrm{O}_{2} \mathrm{~N}\right)$ at $\mathrm{BP} 86 / 6-311+\mathrm{G}(\mathrm{d})$ level of theory with charge $=0$, multiplicity $=2$. Selected calculated bond distances $(\AA)$ and angles $\left({ }^{\circ}\right)$ : N1-Cu 1.930, N2-Cu 1.930, Cu-O1 2.093, Cu-O2 2.093, O1-N3 1.279, O2-N3 1.279; N1-Cu-N2 97.24, N1-Cu-O1 101.21, N2-Cu-O2 101.21, O1-Cu-O2 59.83, O1-N3-O2 110.68. Nitrite stretching frequencies $\left(\mathrm{cm}^{-1}\right): 848$ (symmetric bend), 1137 (asymmetric stretch), 1283 (symmetric

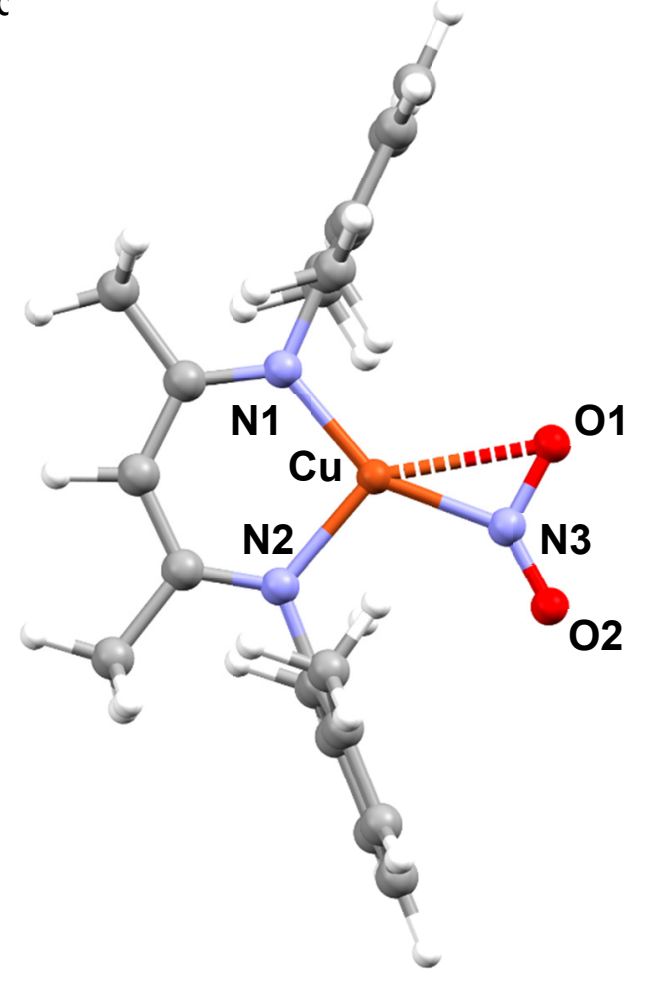

Figure S44. Geometry optimized structure of $\left[\mathrm{Me}_{2} \mathrm{NN}\right] \mathrm{Cu}^{\mathrm{II}}\left(\kappa^{1}-\mathrm{NO}_{2}\right)$ at $\mathrm{BP} 86 / 6-311+\mathrm{G}(\mathrm{d})$ level of theory with charge $=0$, multiplicity $=2$. Selected calculated bond distances $(\AA)$ and angles $\left({ }^{\circ}\right)$ : N1-Cu 1.900, N2-Cu 1.948, Cu-N3 1.923, Cu-O1 2.440 N3-O2 1.225, N3-O1 1.270; N1-Cu-N2 99.50, N1-Cu-O1 119.63, O1-Cu-N3 31.06, N2-Cu-N3 109.82, Cu-N3-O1 97.56, O1-N3-O2 124.08, O2-N3-Cu 138.36. Nitrite stretching frequencies $\left(\mathrm{cm}^{-1}\right): 770$ (symmetric bend), 1219 (N3-O1 stretch), 1456 (N3-O2 stretch). 


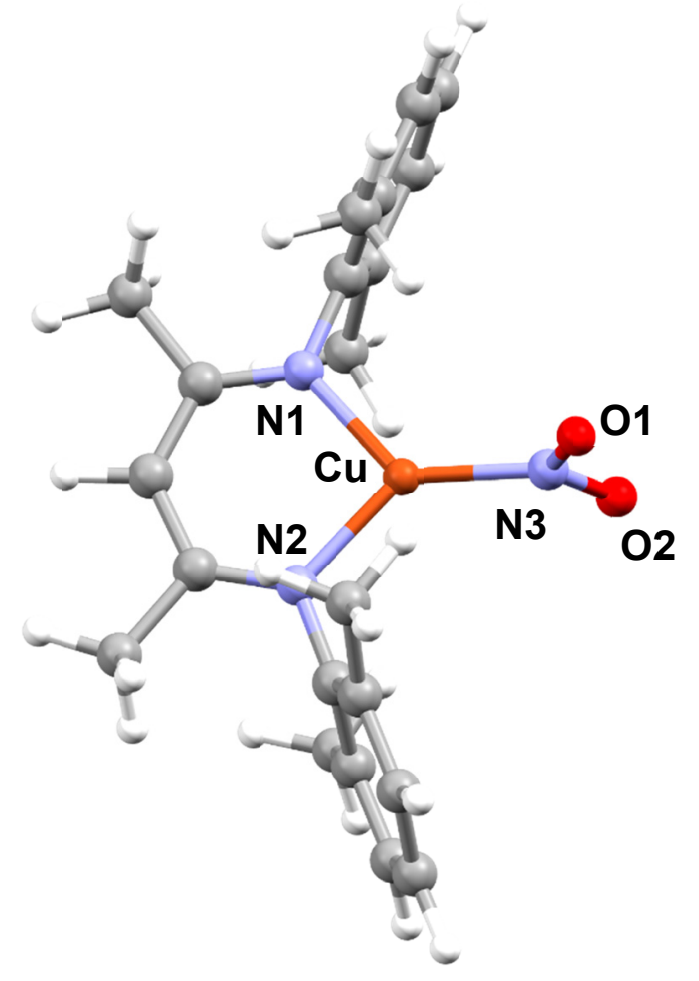

Figure S45. Geometry optimized structure of $\left\{\left[\mathrm{Me}_{2} \mathrm{NN}\right] \mathrm{Cu}^{\mathrm{I}}\left(\kappa^{1}-\mathrm{NO}_{2}\right)\right\}^{-}$at $\mathrm{BP} 86 / 6-311+\mathrm{G}(\mathrm{d})$ level of theory with charge $=-1$, multiplicity $=1$. Selected calculated bond distances $(\AA)$ and angles $\left({ }^{\circ}\right.$ ): $\mathrm{N} 1-\mathrm{Cu} 1.974, \mathrm{~N} 2-\mathrm{Cu} 1.974, \mathrm{Cu}-\mathrm{N} 3$ 1.914, $\mathrm{Cu}-\mathrm{O} 1$ 2.747, $\mathrm{Cu}-\mathrm{O} 22.808, \mathrm{~N} 3-\mathrm{O} 2$ 1.260, N3-O1 1.270; N1-Cu-N2 97.25, N1-Cu-N3 131.21, N2-Cu-N3 131.22, Cu-N3-O1 117.82, O1-N3-O2 119.08, O2-N3-Cu 123.11. Nitrite stretching frequencies $\left(\mathrm{cm}^{-1}\right): 415$ (symmetric N-O stretch), 783 (symmetric bend), 1255 (N3-O1 stretch), 1300 (N3-O2 stretch).

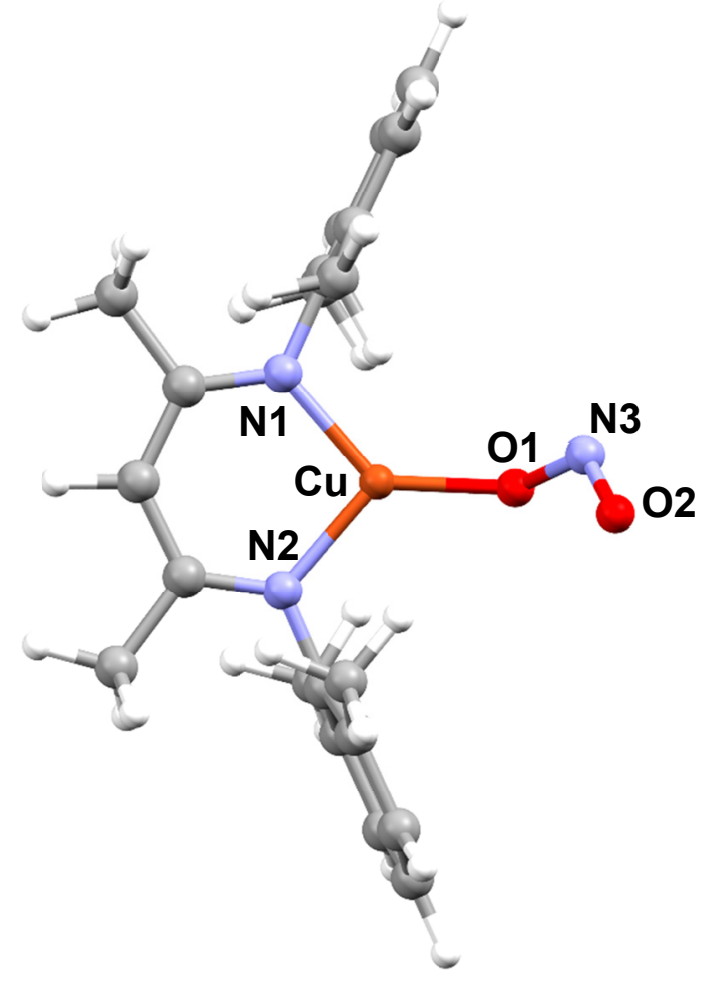

Figure S46. Geometry optimized transition state of $\left[\mathrm{Me}_{2} \mathrm{NN}\right] \mathrm{Cu}^{\text {II }}\left(\kappa^{1}-\mathrm{ONO}\right)$, conversion from $[\mathrm{Cu}]\left(\kappa^{2}-\mathrm{O}_{2} \mathrm{~N}\right)$ to $[\mathrm{Cu}]\left(\kappa^{1}-\mathrm{NO}_{2}\right)$, at $\mathrm{BP} 86 / 6-311+\mathrm{G}(\mathrm{d})$ level of theory with charge $=0$, multiplicity $=2$. Selected calculated bond distances $(\AA)$ and angles $\left({ }^{\circ}\right): \mathrm{N} 1-\mathrm{Cu} 1.916, \mathrm{~N} 2-\mathrm{Cu}$ 1.914, Cu-O1 1.860, N3-O1 1.341, N3-O2 1.209; N1-Cu-N2 98.75, N1-Cu-O1 133.02, N2$\mathrm{Cu}-\mathrm{O} 1$ 128.23, $\mathrm{Cu}-\mathrm{O} 1-\mathrm{N} 3$ 130.41, O1-N3-O2 117.25. 


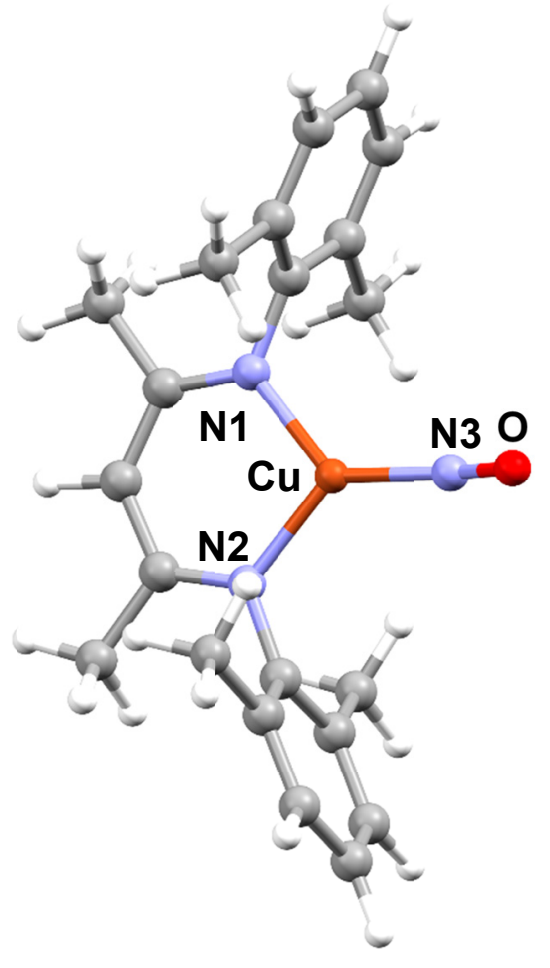

Figure S47. Geometry optimized structure of $\left[\mathrm{Me}_{2} \mathrm{NN}\right] \mathrm{Cu}(\mathrm{NO})$ at $\mathrm{BP} 86 / 6-311+\mathrm{G}(\mathrm{d})$ level of theory with charge $=0$, multiplicity $=2$. Selected calculated bond distances $(\AA)$ and angles $\left.{ }^{\circ}\right): \mathrm{N} 1-\mathrm{Cu} 1.922, \mathrm{~N} 2-\mathrm{Cu} 1.922, \mathrm{Cu}-\mathrm{N} 3$ 1.776, O-N3 1.188; N1-Cu-N2 99.89, N1-Cu-N3 130.04, N2-Cu-N3 130.04, Cu-N3-O 157.94. Nitric oxide stretching frequencies $\left(\mathrm{cm}^{-1}\right): 467$ (Cu-N stretch), 1725 (N-O stretch).

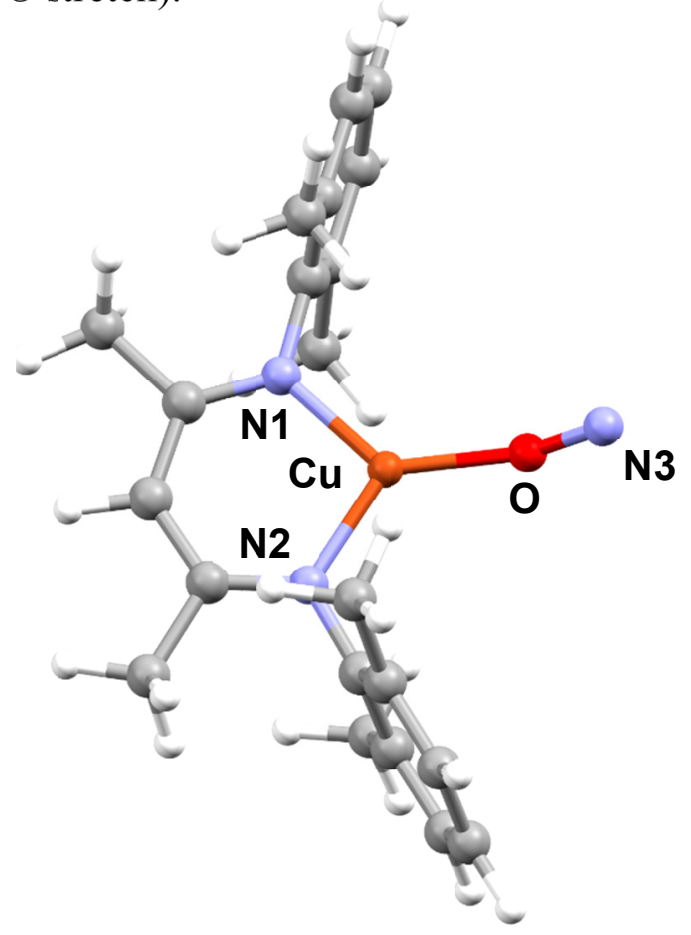

Figure S48. Geometry optimized structure of $\left[\mathrm{Me}_{2} \mathrm{NN}\right] \mathrm{Cu}(\mathrm{ON})$ at $\mathrm{BP} 86 / 6-311+\mathrm{G}(\mathrm{d})$ level of theory with charge $=0$, multiplicity $=2$. Selected calculated bond distances $(\AA)$ and angles $\left.{ }^{\circ}\right): \mathrm{N} 1-\mathrm{Cu} 1.916, \mathrm{~N} 2-\mathrm{Cu} 1.916, \mathrm{Cu}-\mathrm{O}$ 1.887, O-N3 1.202; N1-Cu-N2 102.22, N1-Cu-N3 128.88, N2-Cu-N3 128.88, Cu-O-N3 147.22. Nitric oxide stretching frequencies $\left(\mathrm{cm}^{-1}\right): 343$ (Cu-O stretch), 1560 (N-O stretch). 


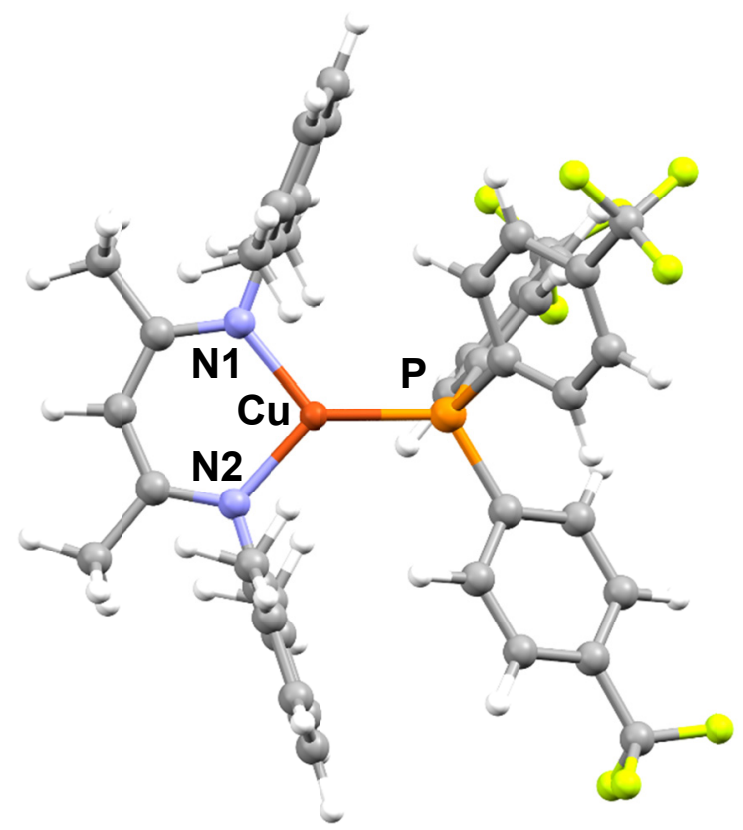

Figure S49. Geometry optimized structure of $\left[\mathrm{Me}_{2} \mathrm{NN}\right] \mathrm{Cu}^{\mathrm{I}}\left(\mathrm{P}\left(\mathrm{Ar}^{\mathrm{CF} 3}\right)_{3}\right)$ at $\mathrm{BP} 86 / 6-311+\mathrm{G}(\mathrm{d})$ level of theory with charge $=0$, multiplicity $=1$. Selected calculated bond distances $(\AA)$ and angles $\left(^{\circ}\right)$ : N1-Cu 1.965, N2-Cu 1.970, Cu-P 2.213; N1-Cu-N2 99.06, N1-Cu-P 132.48, N2$\mathrm{Cu}-\mathrm{P} 128.33$.

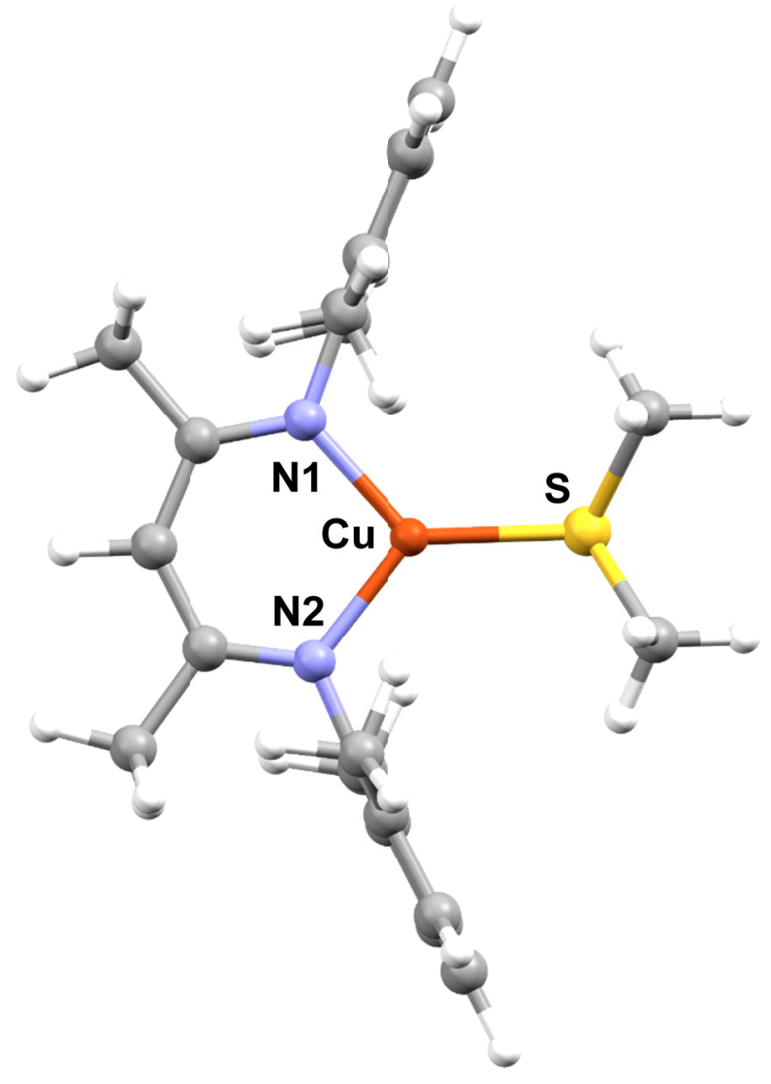

Figure S50. Geometry optimized structure of $\left[\mathrm{Me}_{2} \mathrm{NN}\right] \mathrm{Cu}^{\mathrm{I}}\left(\mathrm{SMe}_{2}\right)$ at $\mathrm{BP} 86 / 6-311+\mathrm{G}(\mathrm{d})$ level of theory with charge $=0$, multiplicity $=1$. Selected calculated bond distances $(\AA)$ and angles $\left.{ }^{\circ}\right)$ : N1-Cu 1.943, N2-Cu 1.943, Cu-S 2.198; N1-Cu-N2 100.55, N1-Cu-S 129.52, N2-Cu-S 129.60 . 


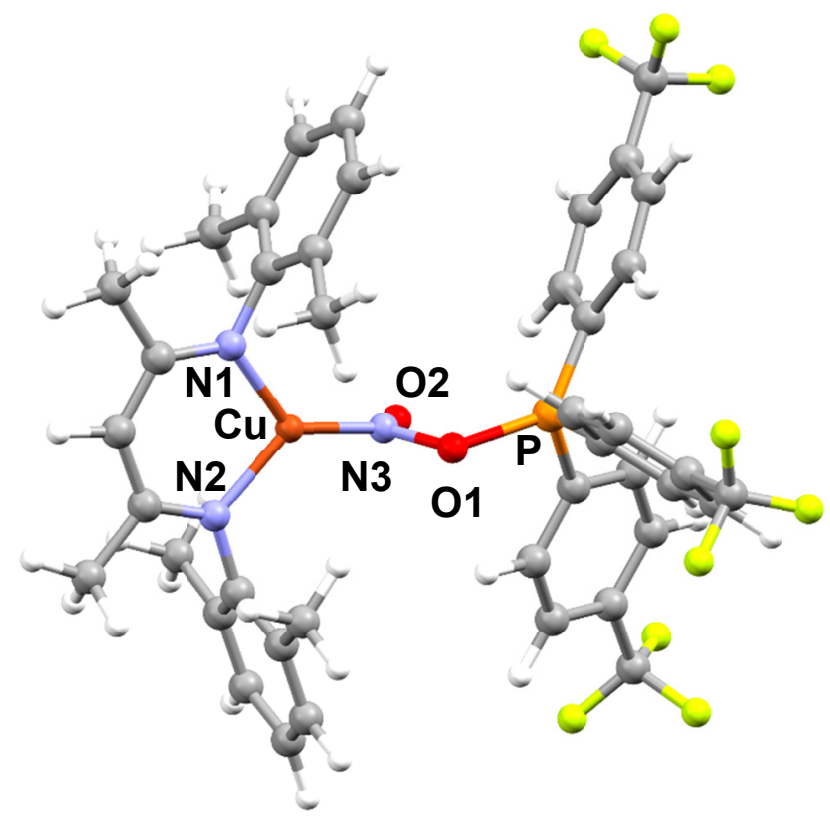

Figure S51. Geometry optimized $\mathrm{TS}_{1}$, the lowest energy $\left(\Delta \mathrm{G}^{\ddagger}=19.1 \mathrm{kcal} / \mathrm{mol}\right)$ $\left(\left[\mathrm{Me}_{2} \mathrm{NN}\right] \mathrm{Cu}-\mathrm{NO}_{2}-90^{\circ}-\mathrm{P}\left(\mathrm{Ar}^{\mathrm{CF} 3}\right)_{3}\right)$ at $\mathrm{BP} 86 / 6-311+\mathrm{G}(\mathrm{d})$ level of theory with charge $=0$, multiplicity $=2$. Selected calculated bond distances $(\AA)$ and angles $\left(^{\circ}\right): \mathrm{N} 1-\mathrm{Cu} 1.929, \mathrm{~N} 2-\mathrm{Cu}$ 1.932, Cu-N3 1.854, O2-N3 1.227, N3-O1 1.441, O1-P 1.861; N1-Cu-N2 99.63, N1-Cu-N3 132.58, N2-Cu-N3 127.67, Cu- N3- O2 131.41, Cu-N3-O1 114.12, O2-N3-O1 114.24, N3O1-P 116.06.

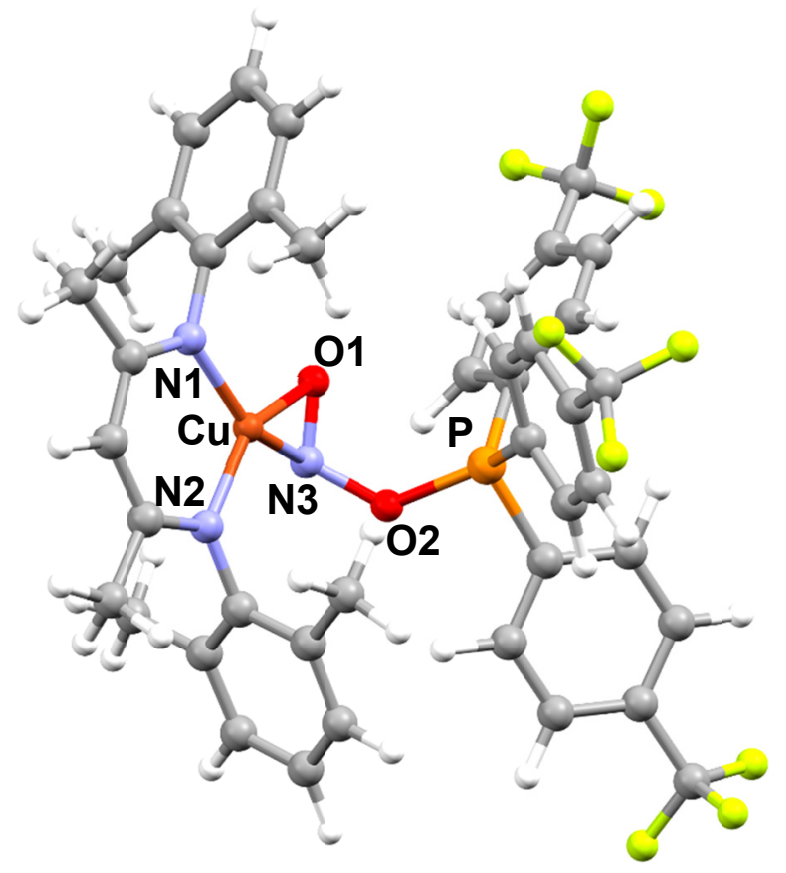

Figure S52. Geometry optimized $\mathrm{TS}_{2}\left(\Delta \mathrm{G}^{\ddagger}=25.4 \mathrm{kcal} / \mathrm{mol}\right)\left(\left[\mathrm{Me}_{2} \mathrm{NN}\right] \mathrm{Cu}-\mathrm{NO}_{2}-\mathrm{P}\left(\mathrm{Ar}^{\mathrm{CF} 3}\right)_{3}\right)$ at $\mathrm{BP} 86 / 6-311+\mathrm{G}(\mathrm{d})$ level of theory with charge $=0$, multiplicity $=2$. Selected calculated bond distances $(\AA)$ and angles $\left(^{\circ}\right): \mathrm{N} 1-\mathrm{Cu} 1.932, \mathrm{~N} 2-\mathrm{Cu} 1.924, \mathrm{Cu}-\mathrm{N} 31.998, \mathrm{~N} 3-\mathrm{O} 11.283, \mathrm{~N} 3-\mathrm{O} 2$ 1.448, O2-P 1.792; N1-Cu-N2 100.71, N1-Cu-N3 147.12, N2-Cu-N3 109.90, Cu-N3-O1 72.78, Cu-N3-O2 124.45, O1-N3-O2 113.38, N3-O2-P 125.67 . 


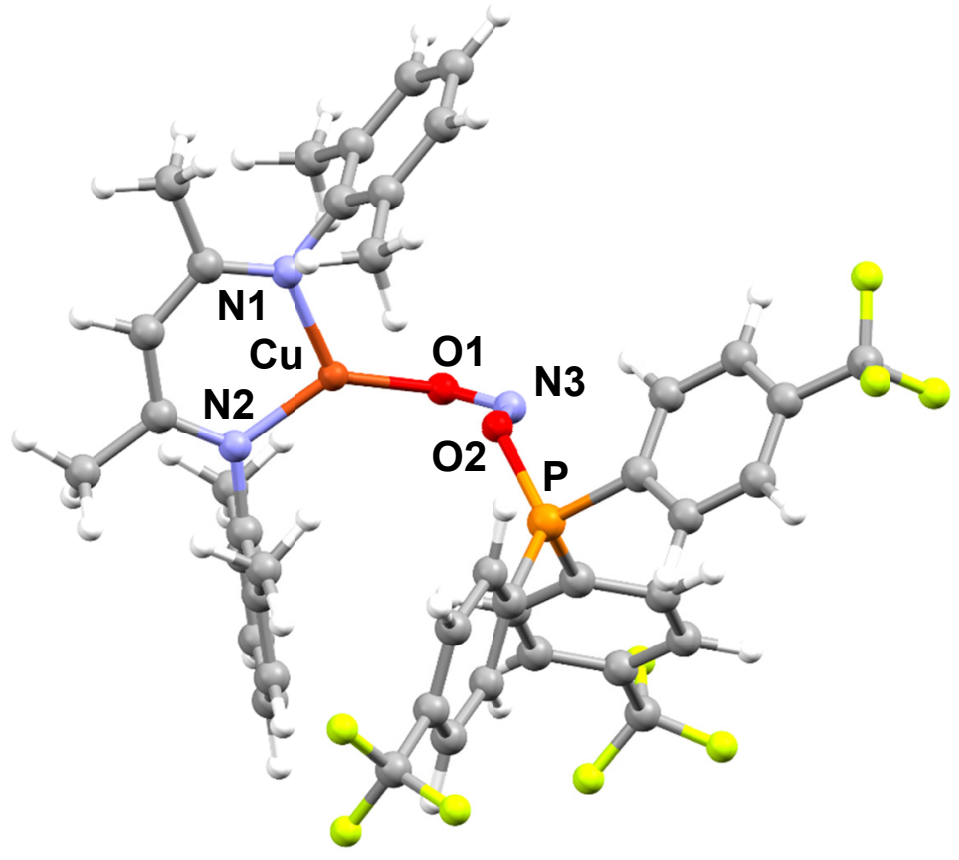

Figure S53. Geometry optimized $\mathrm{TS}_{3}\left(\Delta \mathrm{G}^{*}=27.8 \mathrm{kcal} / \mathrm{mol}\right)\left(\left[\mathrm{Me}_{2} \mathrm{NN}\right] \mathrm{Cu}-\mathrm{ONO}-\mathrm{P}\left(\mathrm{Ar}^{\mathrm{CF} 3}\right)_{3}\right)$ at BP86/6-311+G(d) level of theory with charge $=0$, multiplicity $=2$. Selected calculated bond distances $(\AA)$ and angles $\left(^{\circ}\right): \mathrm{N} 1-\mathrm{Cu} 1.933, \mathrm{~N} 2-\mathrm{Cu} 1.921, \mathrm{Cu}-\mathrm{O} 1$ 1.897, O1-N3 1.245, N3-O2 1.441, O2-P 1.877; N1-Cu-N2 100.65, N1-Cu-O1 125.21, N2-Cu-O1 133.43, Cu-O1N3 130.83, O1-N3-O2 109.77, N3-O2-P 119.55.

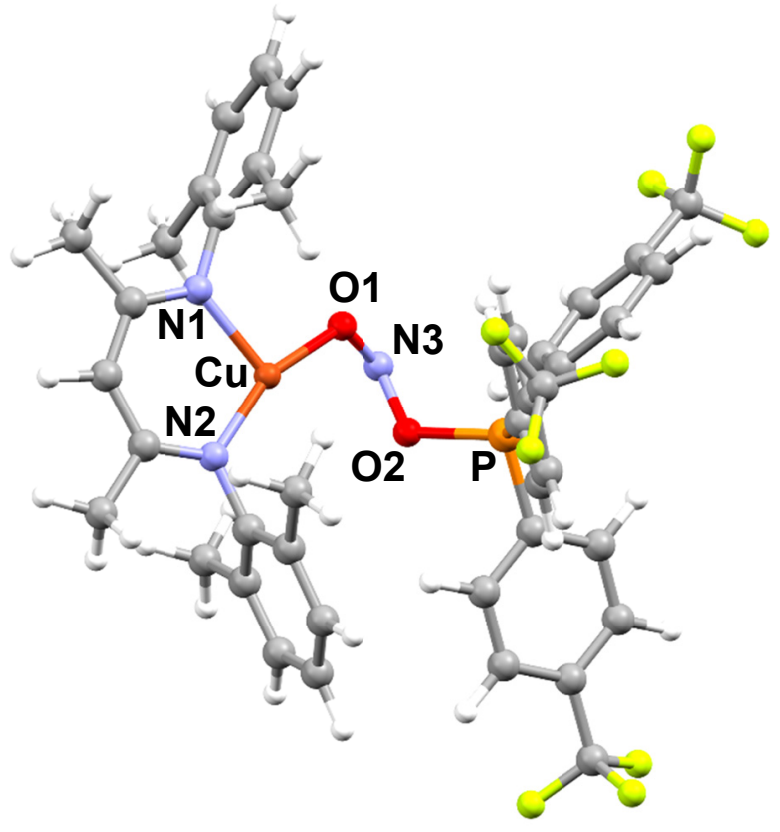

Figure S54. Geometry optimized $\mathrm{TS}_{4}\left(\Delta \mathrm{G}^{*}=31.1 \mathrm{kcal} / \mathrm{mol}\right)\left(\left[\mathrm{Me}_{2} \mathrm{NN}\right] \mathrm{Cu}-\mathrm{O}_{2} \mathrm{~N}-\mathrm{P}\left(\mathrm{Ar}^{\mathrm{CF} 3}\right)_{3}\right)$ at $\mathrm{BP} 86 / 6-311+\mathrm{G}(\mathrm{d})$ level of theory with charge $=0$, multiplicity $=2$. Selected calculated bond distances $(\AA)$ and angles $\left({ }^{\circ}\right)$ :N1-Cu 1.970, N2-Cu 1.906, Cu-O1 1.949, O1-N3 1.265, N3-O2 1.419, O2-P 1.894; N1-Cu-N2 101.77, N1-Cu-O1 99.39, N2-Cu-O1 157.93, Cu-O1-N3 118.68, O1-N3-O2 111.95, N3-O2-P 121.76 . 


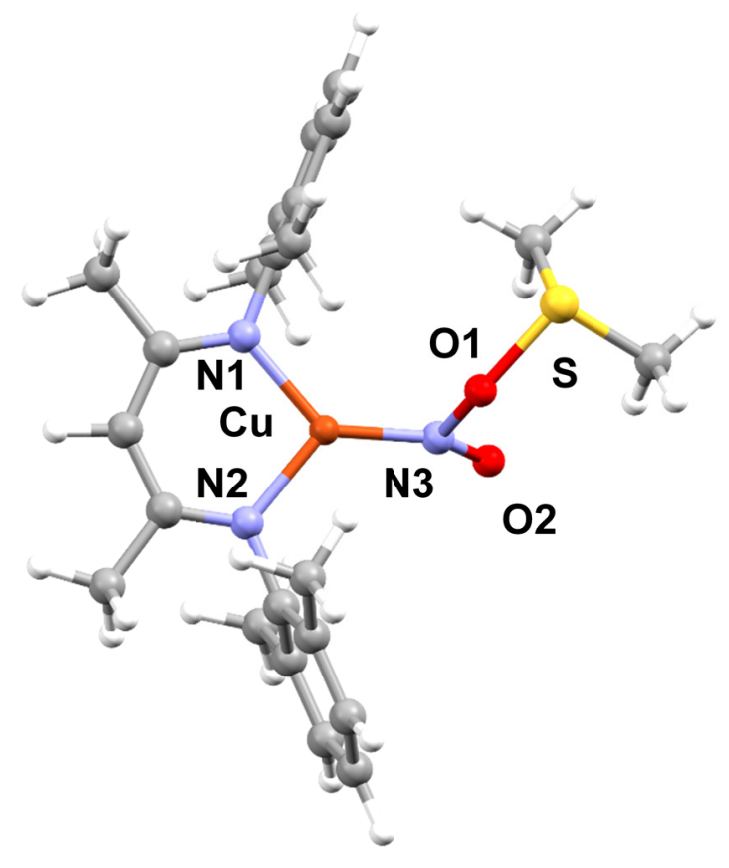

Figure S55. Geometry optimized transition state $\left(\Delta \mathrm{G}^{*}=42.1 \mathrm{kcal} / \mathrm{mol}\right)$ of $\left[\mathrm{Me}_{2} \mathrm{NN}\right] \mathrm{Cu}-$ $\mathrm{NO}_{2}-\mathrm{SMe}_{2}$ at BP86/6-311+G(d) level of theory with charge $=0$, multiplicity $=2$. Selected calculated bond distances $(\AA)$ and angles $\left(^{\circ}\right): \mathrm{N} 1-\mathrm{Cu} 1.940, \mathrm{~N} 2-\mathrm{Cu} 1.937, \mathrm{Cu}-\mathrm{N} 3$ 1.834, N3O1 1.711, N3-O2 1.201, O1-S 1.850; N1-Cu-N2 99.79, N1-Cu-N3 133.53, N2-Cu-N3 126.64, Cu-N3-O1 103.09, Cu-N3-O2 141.78, O1-N3-O2 115.06, N3-O1-S 131.03 .

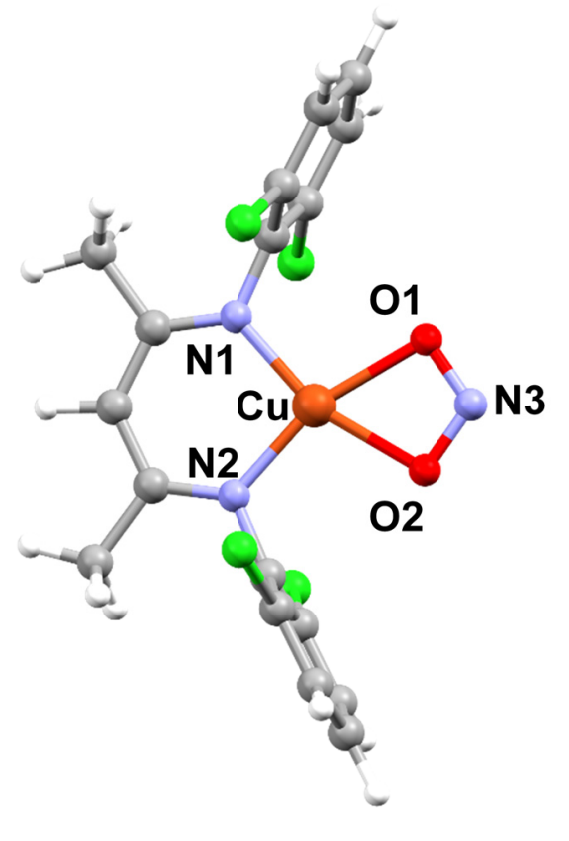

Figure S56. Geometry optimized structure of $\left[\mathrm{Cl}_{2} \mathrm{NN}\right] \mathrm{Cu}^{\mathrm{II}}\left(\kappa^{2}-\mathrm{O}_{2} \mathrm{~N}\right)$ at $\mathrm{BP} 86 / 6-311+\mathrm{G}(\mathrm{d})$ level of theory with charge $=0$, multiplicity $=2$. Selected calculated bond distances $(\AA)$ and angles $\left({ }^{\circ}\right.$ ): $\mathrm{N} 1-\mathrm{Cu} 1.930, \mathrm{~N} 2-\mathrm{Cu} 1.930, \mathrm{Cu}-\mathrm{O} 1$ 2.077, $\mathrm{Cu}-\mathrm{O} 2$ 2.077, O1-N3 1.279, O2-N3 1.279; N1-Cu-N2 96.47, N1-Cu-O1 101.39, N2-Cu-O2 101.39, O1-Cu-O2 60.76, O1-N3-O2 110.38. Nitrite stretching frequencies $\left(\mathrm{cm}^{-1}\right): 847$ (symmetric bend), 1129 (asymmetric stretch), 1256 (symmetric stretch). 


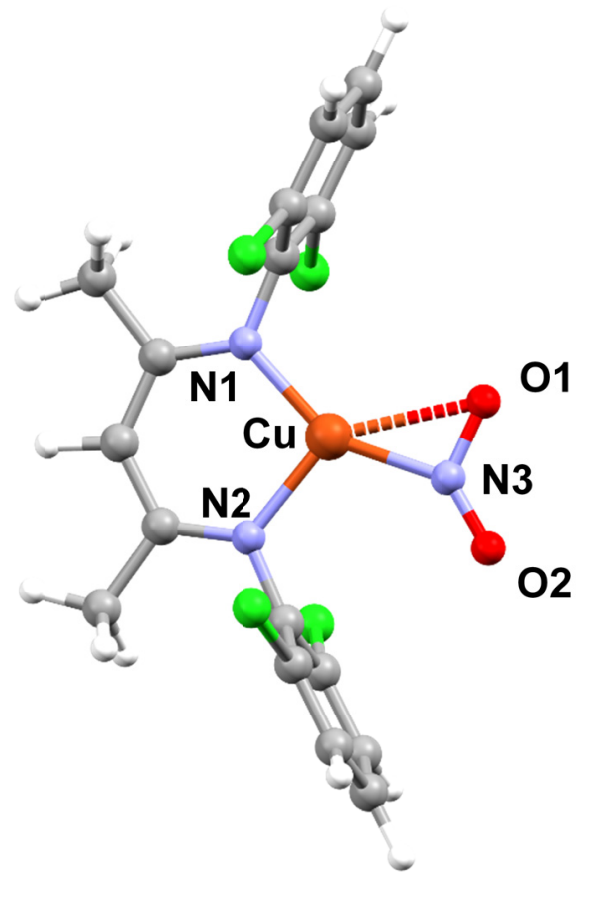

Figure S57. Geometry optimized structure of $\left[\mathrm{Cl}_{2} \mathrm{NN}\right] \mathrm{Cu}^{\mathrm{II}}\left(\kappa^{1}-\mathrm{NO}_{2}\right)$ at $\mathrm{BP} 86 / 6-311+\mathrm{G}(\mathrm{d})$ level of theory with charge $=0$, multiplicity $=2$. Selected calculated bond distances $(\AA)$ and angles $\left({ }^{\circ}\right)$ : N1-Cu 1.905, N2-Cu 1.945, Cu-N3 1.919, Cu-O1 2.406, N3-O2 1.222, N3-O1 1.269; N1-Cu-N2 98.88, N1-Cu-O1 119.71, O1-Cu-N3 31.63, N2-Cu-N3 109.78, Cu-N3-O1 95.88, O1-N3-O2 124.71, O2-N3-Cu 139.41. Nitrite stretching frequencies $\left(\mathrm{cm}^{-1}\right): 768$ (symmetric bend), 1215 (N3-O1 stretch), 1472 (N3-O2 stretch).

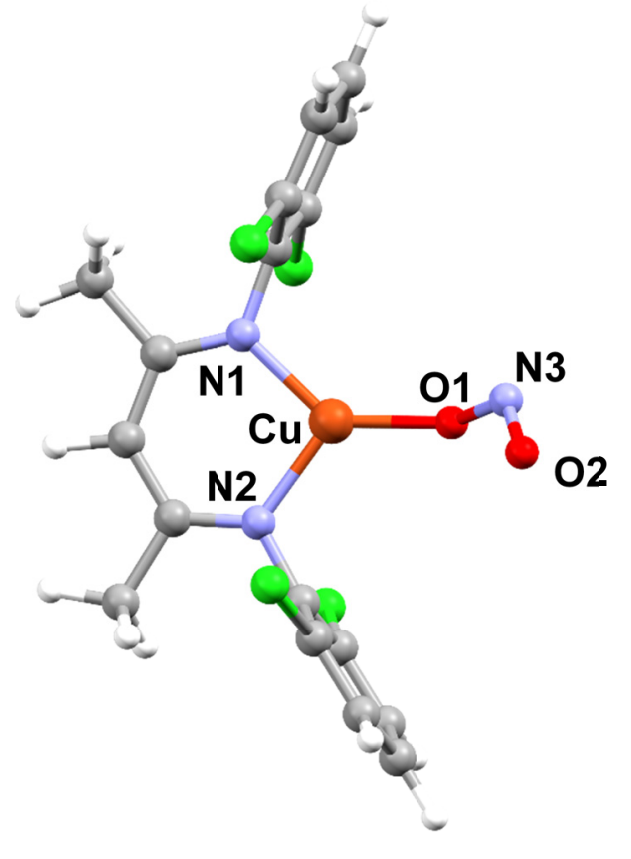

Figure S58. Geometry optimized transition state of $\left[\mathrm{Cl}_{2} \mathrm{NN}\right] \mathrm{Cu}^{\mathrm{II}}\left(\kappa^{1}-\mathrm{ONO}\right)$, conversion from $[\mathrm{Cu}]\left(\kappa^{2}-\mathrm{O}_{2} \mathrm{~N}\right)$ to $[\mathrm{Cu}]\left(\kappa^{1}-\mathrm{NO}_{2}\right)$, at $\mathrm{BP} 86 / 6-311+\mathrm{G}(\mathrm{d})$ level of theory with charge $=0$, multiplicity $=2$. Selected calculated bond distances $(\AA)$ and angles $\left({ }^{\circ}\right): \mathrm{N} 1-\mathrm{Cu} 1.916, \mathrm{~N} 2-\mathrm{Cu}$ 1.921, Cu-O1 1.859, N3-O1 1.329, N3-O2 1.208; N1-Cu-N2 98.24, N1-Cu-O1 136.57, N2$\mathrm{Cu}-\mathrm{O} 1$ 125.16, Cu-O1-N3 134.44, O1-N3-O2 118.57. 


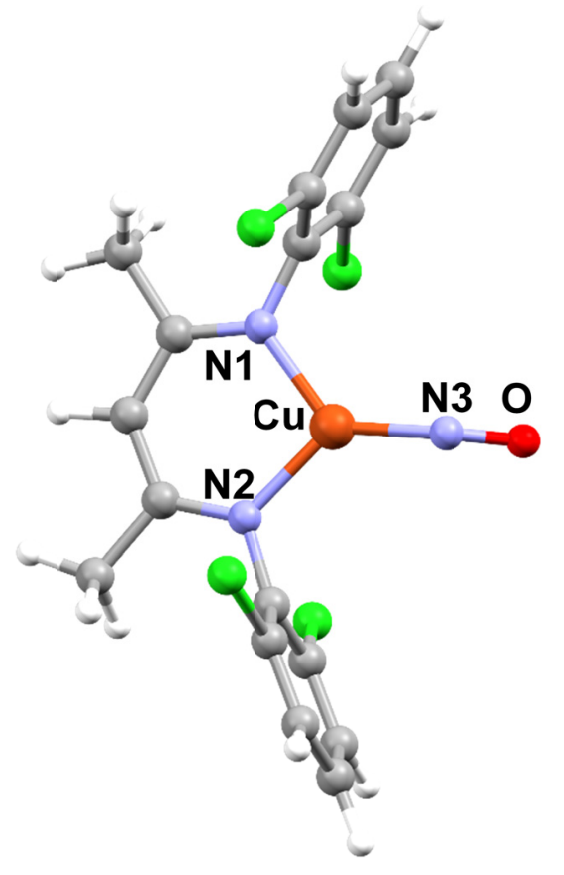

Figure S59. Geometry optimized structure of $\left[\mathrm{Cl}_{2} \mathrm{NN}\right] \mathrm{Cu}(\mathrm{NO})$ at $\mathrm{BP} 86 / 6-311+\mathrm{G}(\mathrm{d})$ level of theory with charge $=0$, multiplicity $=2$. Selected calculated bond distances $(\AA)$ and angles ( ${ }^{\circ}: \mathrm{N} 1-\mathrm{Cu} 1.927, \mathrm{~N} 2-\mathrm{Cu} 1.927, \mathrm{Cu}-\mathrm{N} 3$ 1.782, O-N3 1.186; N1-Cu-N2 99.01, N1-Cu-N3 130.48, N2-Cu-N3 130.48, Cu-N3-O 154.44. Nitric oxide stretching frequencies $\left(\mathrm{cm}^{-1}\right): 475$ (Cu-N stretch), 1734 (N-O stretch).

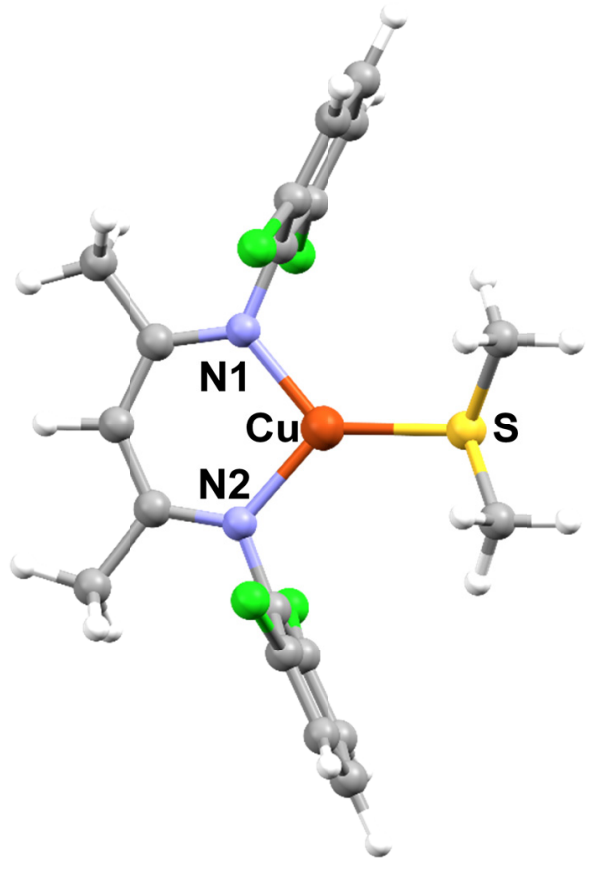

Figure S60. Geometry optimized structure of $\left[\mathrm{Me}_{2} \mathrm{NN}\right] \mathrm{Cu}^{\mathrm{I}}\left(\mathrm{SMe}_{2}\right)$ at $\mathrm{BP} 86 / 6-311+\mathrm{G}(\mathrm{d})$ level of theory with charge $=0$, multiplicity $=1$. Selected calculated bond distances $(\AA)$ and angles $\left.{ }^{\circ}\right)$ : N1-Cu 1.947, N2-Cu 1.947, Cu-S 2.206; N1-Cu-N2 99.49, N1-Cu-S 130.23, N2-Cu-S 130.23 . 


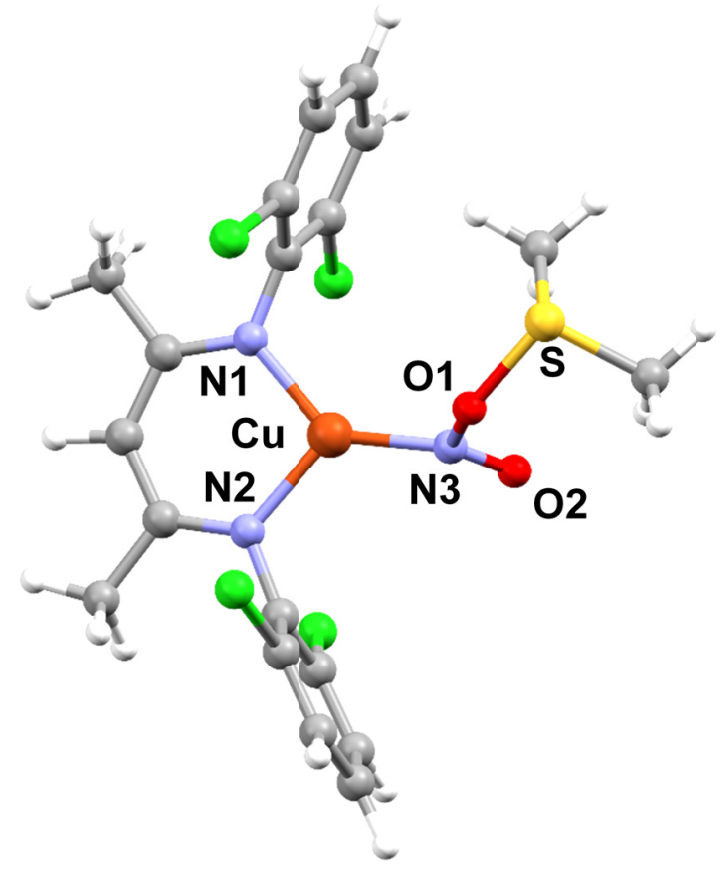

Figure S61. Geometry optimized transition state $\left(\Delta \mathrm{G}^{*}=38.5 \mathrm{kcal} / \mathrm{mol}\right)$ of $\left[\mathrm{Cl}_{2} \mathrm{NN}\right] \mathrm{Cu}^{-} \mathrm{NO}_{2}$ $\mathrm{SMe}_{2}$ at BP86/6-311+G(d) level of theory with charge $=0$, multiplicity $=2$. Selected calculated bond distances $(\AA)$ and angles $\left({ }^{\circ}\right)$ : N1-Cu 1.944, N2-Cu 1.946, Cu-N3 1.845, N3O1 1.691, N3-O2 1.202, O1-S 1.833; N1-Cu-N2 98.78, N1-Cu-N3 136.00, N2-Cu-N3 125.06, Cu-N3-O1 104.88, Cu-N3-O2 140.08, O1-N3-O2 115.03, N3-O1-S 129.39 . 


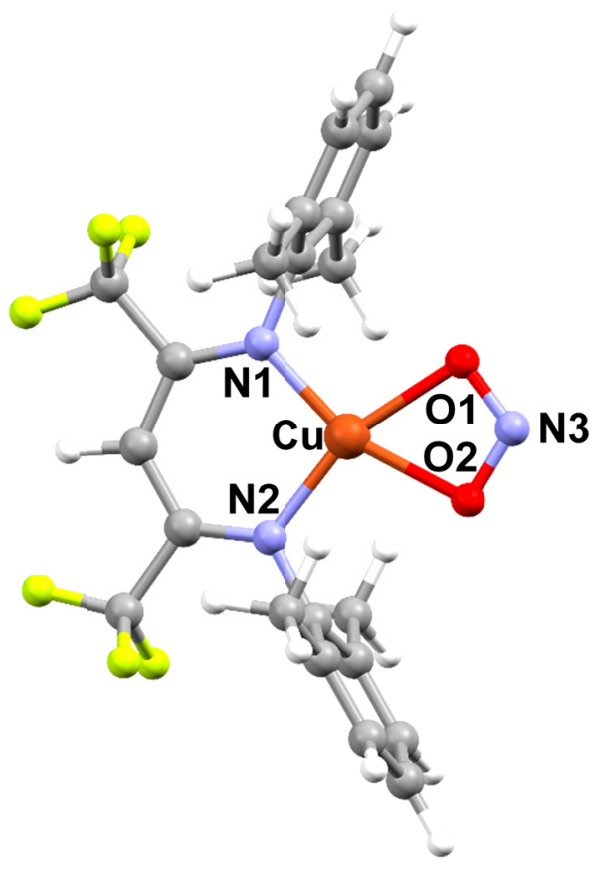

Figure S62. Geometry optimized structure of $\left[\mathrm{Me}_{2} \mathrm{NN}_{\mathrm{F} 6}\right] \mathrm{Cu}^{\mathrm{II}}\left(\kappa^{2}-\mathrm{O}_{2} \mathrm{~N}\right)$ at $\mathrm{BP} 86 / 6-311+\mathrm{G}(\mathrm{d})$ level of theory with charge $=0$, multiplicity $=2$. Selected calculated bond distances $(\AA)$ and angles $\left({ }^{\circ}\right): \mathrm{N} 1-\mathrm{Cu} 1.941, \mathrm{~N} 2-\mathrm{Cu} 1.941, \mathrm{Cu}-\mathrm{O} 12.091, \mathrm{Cu}-\mathrm{O} 2$ 2.091, O1-N3 1.278, O2-N3 1.278; N1-Cu-N2 98.29, N1-Cu-O1 100.71, N2-Cu-O2 100.71, O1-Cu-O2 60.30, O1-N3-O2 110.53. Nitrite stretching frequencies $\left(\mathrm{cm}^{-1}\right)$ : 848 (symmetric bend), 1133 (asymmetric stretch), 1255 (symmetric stretch).

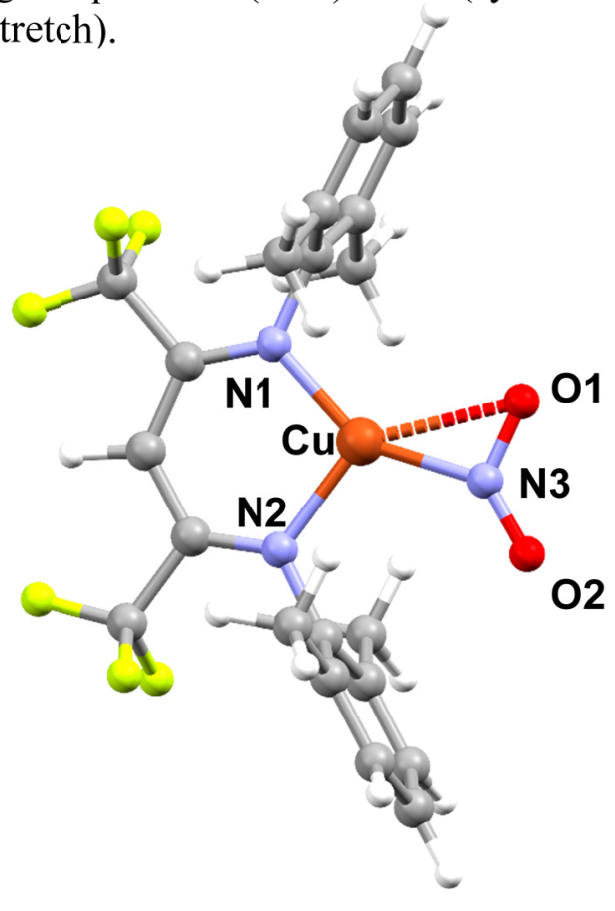

Figure S63. Geometry optimized structure of $\left[\mathrm{Me}_{2} \mathrm{NN}_{\mathrm{F} 6}\right] \mathrm{Cu}^{\mathrm{II}}\left(\kappa^{1}-\mathrm{NO}_{2}\right)$ at $\mathrm{BP} 86 / 6-311+\mathrm{G}(\mathrm{d})$ level of theory with charge $=0$, multiplicity $=2$. Selected calculated bond distances $(\AA)$ and angles $\left({ }^{\circ}\right)$ : N1-Cu 1.907, N2-Cu 1.960, Cu-N3 1.927, Cu-O1 2.442, N3-O2 1.228, N3-O1 1.268; N1-Cu-N2 100.41, N1-Cu-O1 118.76, O1-Cu-N3 30.98, N2-Cu-N3 109.85, Cu-N3O1 97.56, O1-N3-O2 124.62, O2-N3-Cu 137.83. Nitrite stretching frequencies $\left(\mathrm{cm}^{-1}\right): 769$ (symmetric bend), 1218 (N3-O1 stretch), 1463 (N3-O2 stretch). 


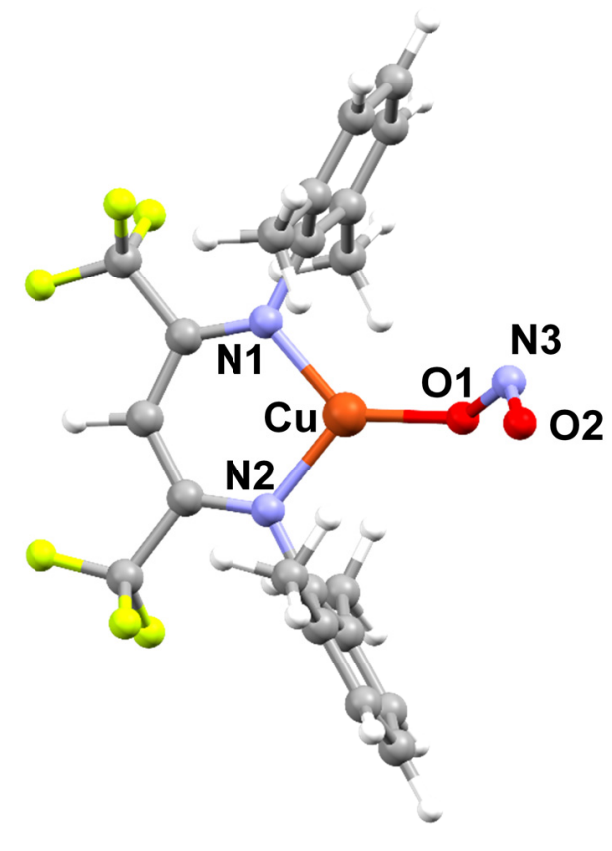

Figure S64. Geometry optimized transition state of $\left[\mathrm{Me}_{2} \mathrm{NN}_{\mathrm{F} 6}\right] \mathrm{Cu}^{\mathrm{II}}\left(\kappa^{1}-\mathrm{ONO}\right)$, conversion from $[\mathrm{Cu}]\left(\kappa^{2}-\mathrm{O}_{2} \mathrm{~N}\right)$ to $[\mathrm{Cu}]\left(\kappa^{1}-\mathrm{NO}_{2}\right)$, at $\mathrm{BP} 86 / 6-311+\mathrm{G}(\mathrm{d})$ level of theory with charge $=0$, multiplicity $=2$. Selected calculated bond distances $(\AA)$ and angles $\left(^{\circ}\right): \mathrm{N} 1-\mathrm{Cu} 1.922, \mathrm{~N} 2-\mathrm{Cu}$ 1.923, Cu-O1 1.862, N3-O1 1.336, N3-O2 1.207; N1-Cu-N2 99.97, N1-Cu-O1 132.93, N2$\mathrm{Cu}-\mathrm{O} 1$ 127.09, $\mathrm{Cu}-\mathrm{O} 1-\mathrm{N} 3$ 130.73, O1-N3-O2 118.12.

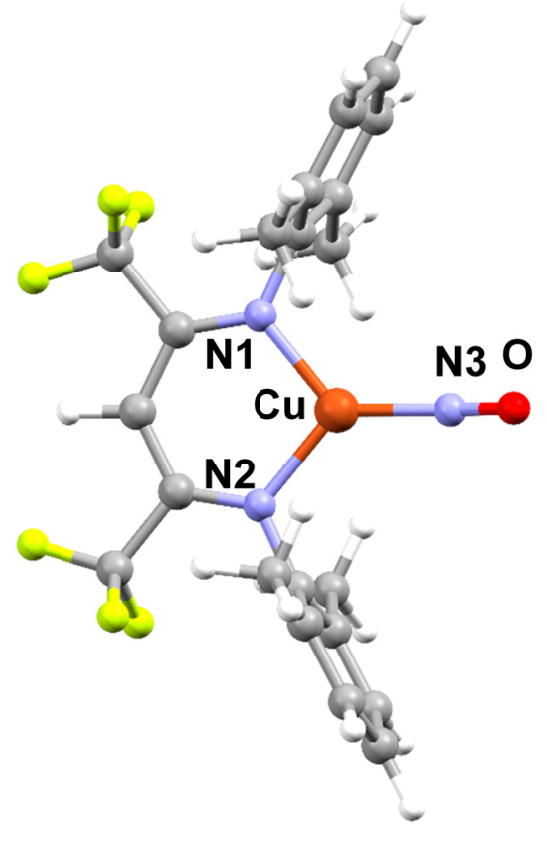

Figure S65. Geometry optimized structure of $\left[\mathrm{Me}_{2} \mathrm{NN}_{\mathrm{F}}\right] \mathrm{Cu}(\mathrm{NO})$ at $\mathrm{BP} 86 / 6-311+\mathrm{G}(\mathrm{d})$ level of theory with charge $=0$, multiplicity $=2$. Selected calculated bond distances $(\AA)$ and angles $\left({ }^{\circ}\right): \mathrm{N} 1-\mathrm{Cu} 1.929, \mathrm{~N} 2-\mathrm{Cu} 1.929, \mathrm{Cu}-\mathrm{N} 3$ 1.785, O-N3 1.184; N1-Cu-N2 101.00, N1-Cu-N3 129.47, N2-Cu-N3 129.47, Cu-N3-O 155.07. Nitric oxide stretching frequencies $\left(\mathrm{cm}^{-1}\right)$ : 461 (Cu-N stretch), 1740 (N-O stretch). 


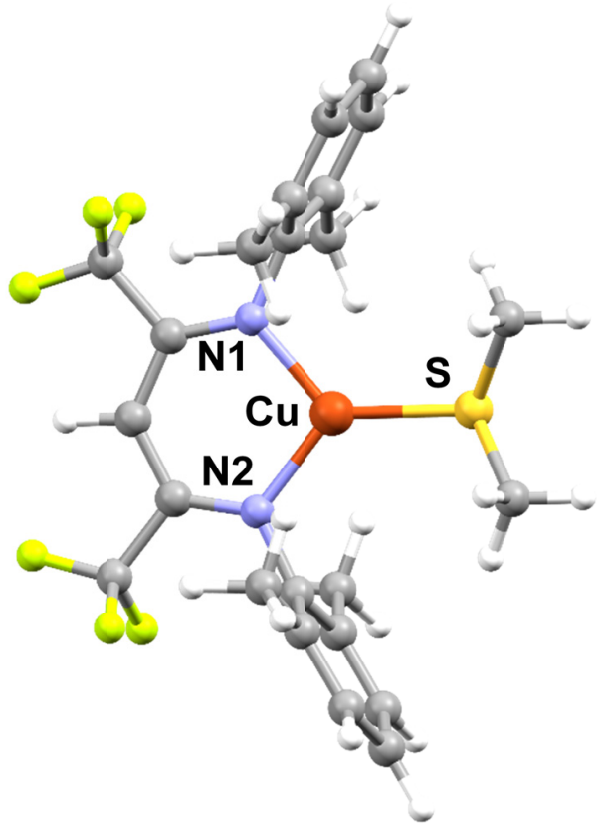

Figure S66. Geometry optimized structure of $\left[\mathrm{Me}_{2} \mathrm{NN}_{\mathrm{F} 6}\right] \mathrm{Cu}^{\mathrm{I}}\left(\mathrm{SMe}_{2}\right)$ at $\mathrm{BP} 86 / 6-311+\mathrm{G}(\mathrm{d})$ level of theory with charge $=0$, multiplicity $=1$. Selected calculated bond distances $(\AA)$ and angles $\left({ }^{\circ}\right)$ : N1-Cu 1.948, N2-Cu 1.948, Cu-S 2.206; N1-Cu-N2 101.33, N1-Cu-S 129.15, N2$\mathrm{Cu}-\mathrm{S} 129.15$.

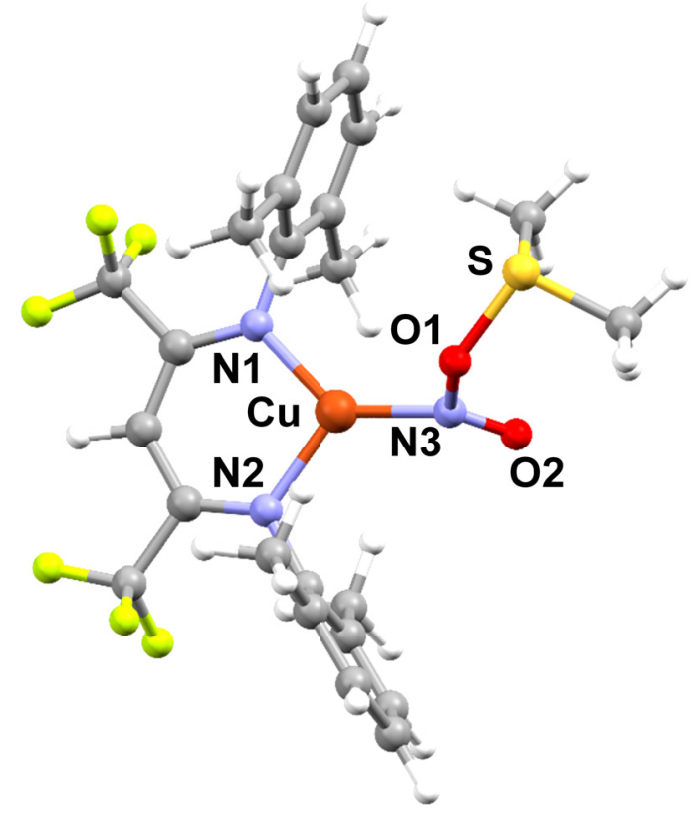

Figure S67. Geometry optimized transition state $\left(\Delta \mathrm{G}^{\ddagger}=36.0 \mathrm{kcal} / \mathrm{mol}\right)$ of $\left[\mathrm{Me}_{2} \mathrm{NN}_{\mathrm{F} 6}\right] \mathrm{Cu}-$ $\mathrm{NO}_{2}-\mathrm{SMe}_{2}$ at BP86/6-311+G(d) level of theory with charge $=0$, multiplicity $=2$. Selected calculated bond distances $(\AA)$ and angles $\left(^{\circ}\right): \mathrm{N} 1-\mathrm{Cu} 1.945, \mathrm{~N} 2-\mathrm{Cu} 1.948, \mathrm{Cu}-\mathrm{N} 31.850, \mathrm{~N} 3-$ O1 1.677, N3-O2 1.203, O1-S 1.836; N1-Cu-N2 100.93, N1-Cu-N3 134.55, N2-Cu-N3 124.49, Cu-N3-O1 104.09, Cu-N3-O2 140.67, O1-N3-O2 115.23, N3-O1-S 127.92. 


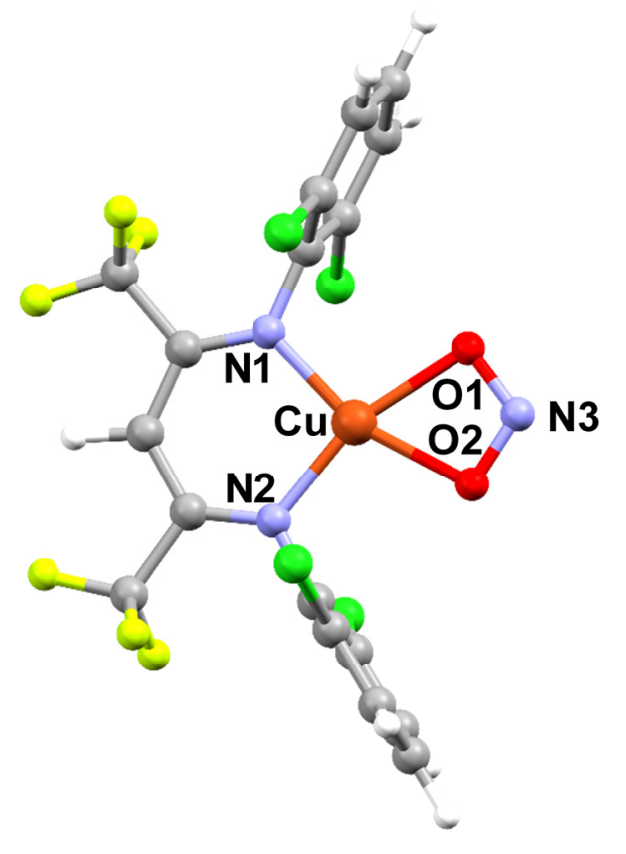

Figure S68. Geometry optimized structure of $\left[\mathrm{Cl}_{2} \mathrm{NN}_{\mathrm{F} 6}\right] \mathrm{Cu}^{\mathrm{II}}\left(\kappa^{2}-\mathrm{O}_{2} \mathrm{~N}\right)$ at $\mathrm{BP} 86 / 6-311+\mathrm{G}(\mathrm{d})$ level of theory with charge $=0$, multiplicity $=2$. Selected calculated bond distances $(\AA)$ and angles $\left({ }^{\circ}\right)$ : N1-Cu 1.941, N2-Cu 1.941, Cu-O1 2.073, Cu-O2 2.073, O1-N3 1.279, O2-N3 1.279; N1-Cu-N2 97.26, N1-Cu-O1 100.97, N2-Cu-O2 100.97, O1-Cu-O2 60.79, O1-N3-O2 110.17. Nitrite stretching frequencies $\left(\mathrm{cm}^{-1}\right): 847$ (symmetric bend), 1123 (asymmetric stretch), 1258 (symmetric stretch).

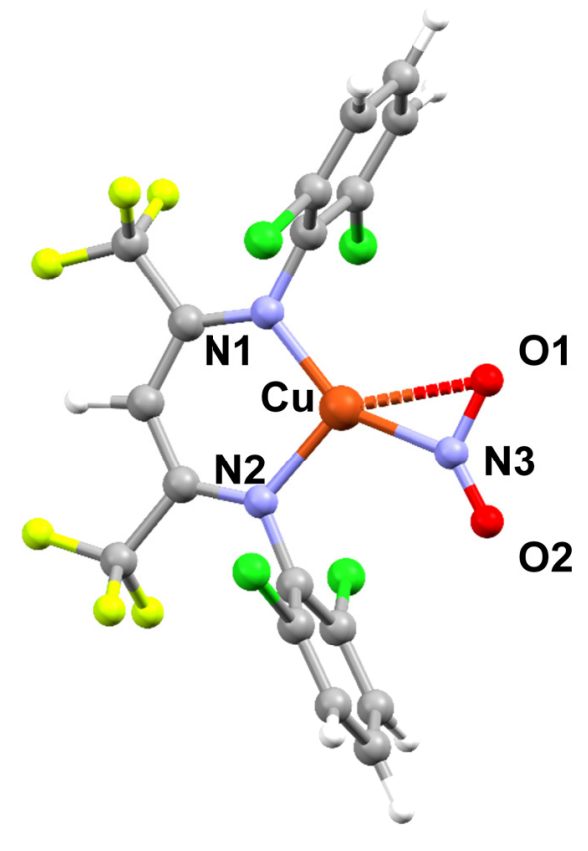

Figure S69. Geometry optimized structure of $\left[\mathrm{Cl}_{2} \mathrm{NN}_{\mathrm{F} 6}\right] \mathrm{Cu}^{\mathrm{II}}\left(\kappa^{1}-\mathrm{NO}_{2}\right)$ at $\mathrm{BP} 86 / 6-311+\mathrm{G}(\mathrm{d})$ level of theory with charge $=0$, multiplicity $=2$. Selected calculated bond distances $(\AA)$ and angles $\left({ }^{\circ}\right.$ ): $\mathrm{N} 1-\mathrm{Cu} 1.911, \mathrm{~N} 2-\mathrm{Cu} 1.955, \mathrm{Cu}-\mathrm{N} 3$ 1.922, Cu-O1 2.393 N3-O2 1.219, N3-O1 1.268; N1-Cu-N2 99.68, N1-Cu-O1 118.53, O1-Cu-N3 31.85, N2-Cu-N3 109.94, Cu-N3-O1 94.98, O1-N3-O2 125.31, O2-N3-Cu 139.71. Nitrite stretching frequencies $\left(\mathrm{cm}^{-1}\right): 767$ (symmetric bend), 1212 (N3-O1 stretch), 1482 (N3-O2 stretch). 


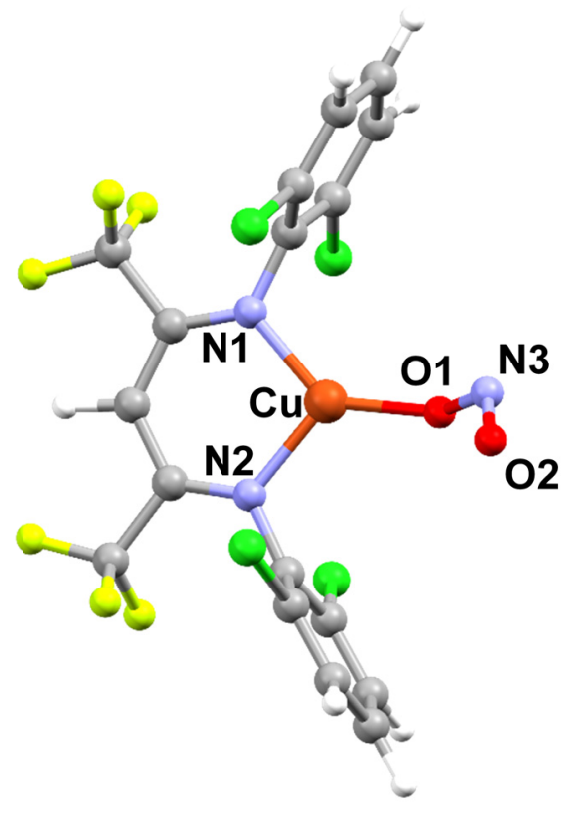

Figure S70. Geometry optimized transition state of $\left[\mathrm{Cl}_{2} \mathrm{NN}_{\mathrm{F} 6}\right] \mathrm{Cu}^{\mathrm{II}}\left(\kappa^{1}-\mathrm{ONO}\right)$, conversion from $[\mathrm{Cu}]\left(\kappa^{2}-\mathrm{O}_{2} \mathrm{~N}\right)$ to $[\mathrm{Cu}]\left(\kappa^{1}-\mathrm{NO}_{2}\right)$, at $\mathrm{BP} 86 / 6-311+\mathrm{G}(\mathrm{d})$ level of theory with charge $=0$, multiplicity $=2$. Selected calculated bond distances $(\AA)$ and angles $\left({ }^{\circ}\right): \mathrm{N} 1-\mathrm{Cu} 1.921, \mathrm{~N} 2-\mathrm{Cu}$ 1.930, Cu-O1 1.863, N3-O1 1.321, N3-O2 1.205; N1-Cu-N2 99.41, N1-Cu-O1 136.55, N2Cu-O1 124.01, Cu-O1-N3 134.89, O1-N3-O2 119.72.

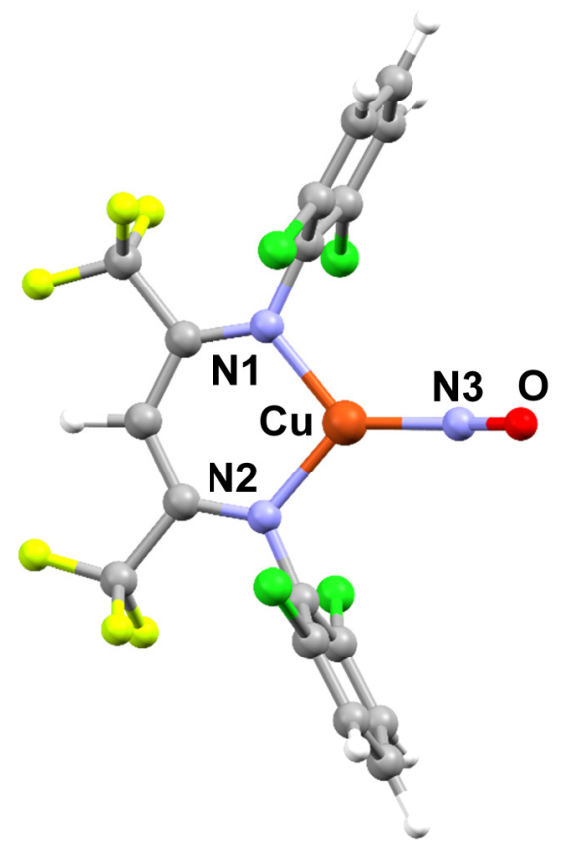

Figure S71. Geometry optimized structure of $\left[\mathrm{Cl}_{2} \mathrm{NN}_{\mathrm{F} 6}\right] \mathrm{Cu}(\mathrm{NO})$ at $\mathrm{BP} 86 / 6-311+\mathrm{G}(\mathrm{d})$ level of theory with charge $=0$, multiplicity $=2$. Selected calculated bond distances $(\AA)$ and angles $\left({ }^{\circ}\right): \mathrm{N} 1-\mathrm{Cu} 1.934, \mathrm{~N} 2-\mathrm{Cu} 1.934, \mathrm{Cu}-\mathrm{N} 3$ 1.790, O-N3 1.182; N1-Cu-N2 99.92, N1-Cu-N3 130.02, N2-Cu-N3 130.02, Cu-N3-O 152.23. Nitric oxide stretching frequencies $\left(\mathrm{cm}^{-1}\right): 452$ (Cu-N stretch), 1749 (N-O stretch). 


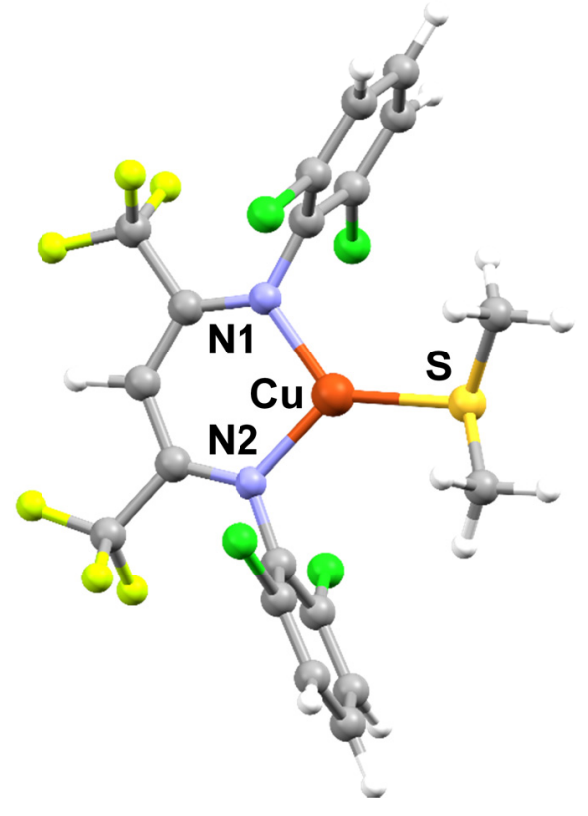

Figure S72. Geometry optimized structure of $\left[\mathrm{Cl}_{2} \mathrm{NN}_{\mathrm{F} 6}\right] \mathrm{Cu}^{\mathrm{I}}\left(\mathrm{SMe}_{2}\right)$ at $\mathrm{BP} 86 / 6-311+\mathrm{G}(\mathrm{d})$ level of theory with charge $=0$, multiplicity $=1$. Selected calculated bond distances $(\AA)$ and angles $\left({ }^{\circ}\right)$ : N1-Cu 1.952, N2-Cu 1.952, Cu-S 2.213; N1-Cu-N2 100.19, N1-Cu-S 129.88, N2Cu-S 129.88 .

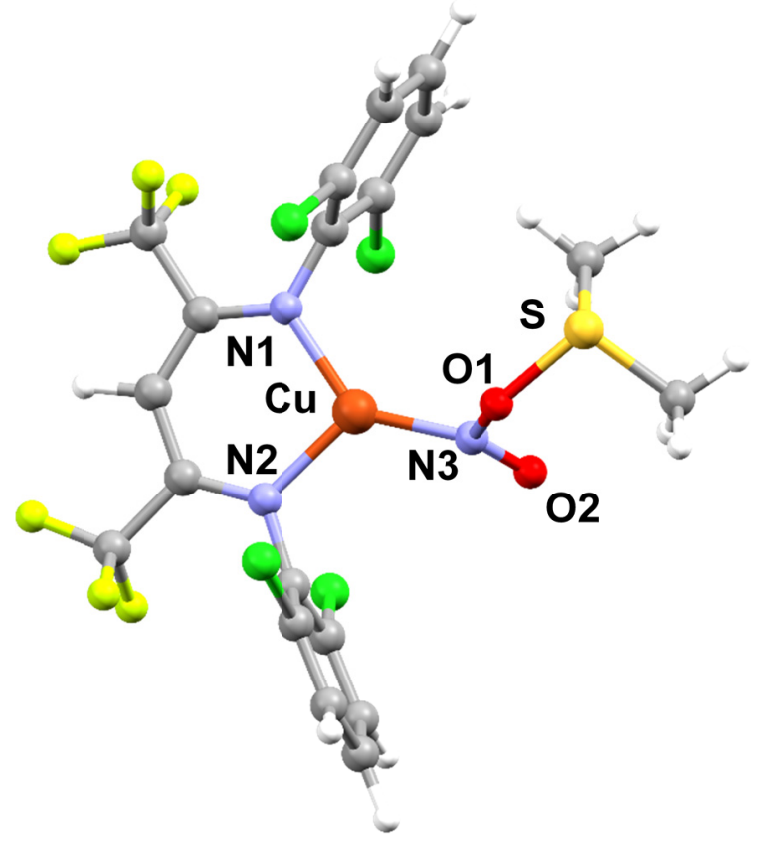

Figure S73. Geometry optimized transition state $\left(\Delta \mathrm{G}^{*}=33.0 \mathrm{kcal} / \mathrm{mol}\right)$ of $\left[\mathrm{Cl}_{2} \mathrm{NN}_{\mathrm{F} 6}\right] \mathrm{Cu}-$ $\mathrm{NO}_{2}-\mathrm{SMe}_{2}$ at $\mathrm{BP} 86 / 6-311+\mathrm{G}(\mathrm{d})$ level of theory with charge $=0$, multiplicity $=2$. Selected calculated bond distances $(\AA)$ and angles $\left({ }^{\circ}\right): \mathrm{N} 1-\mathrm{Cu} 1.948, \mathrm{~N} 2-\mathrm{Cu} 1.957, \mathrm{Cu}-\mathrm{N} 31.859, \mathrm{~N} 3-$ $\mathrm{O} 1$ 1.658, N3-O2 1.205, O1-S 1.823; N1-Cu-N2 99.68, N1-Cu-N3 136.85, N2-Cu-N3 123.32, Cu-N3-O1 105.78, Cu-N3-O2 139.08, O1-N3-O2 115.12, N3-O1-S 126.40. 

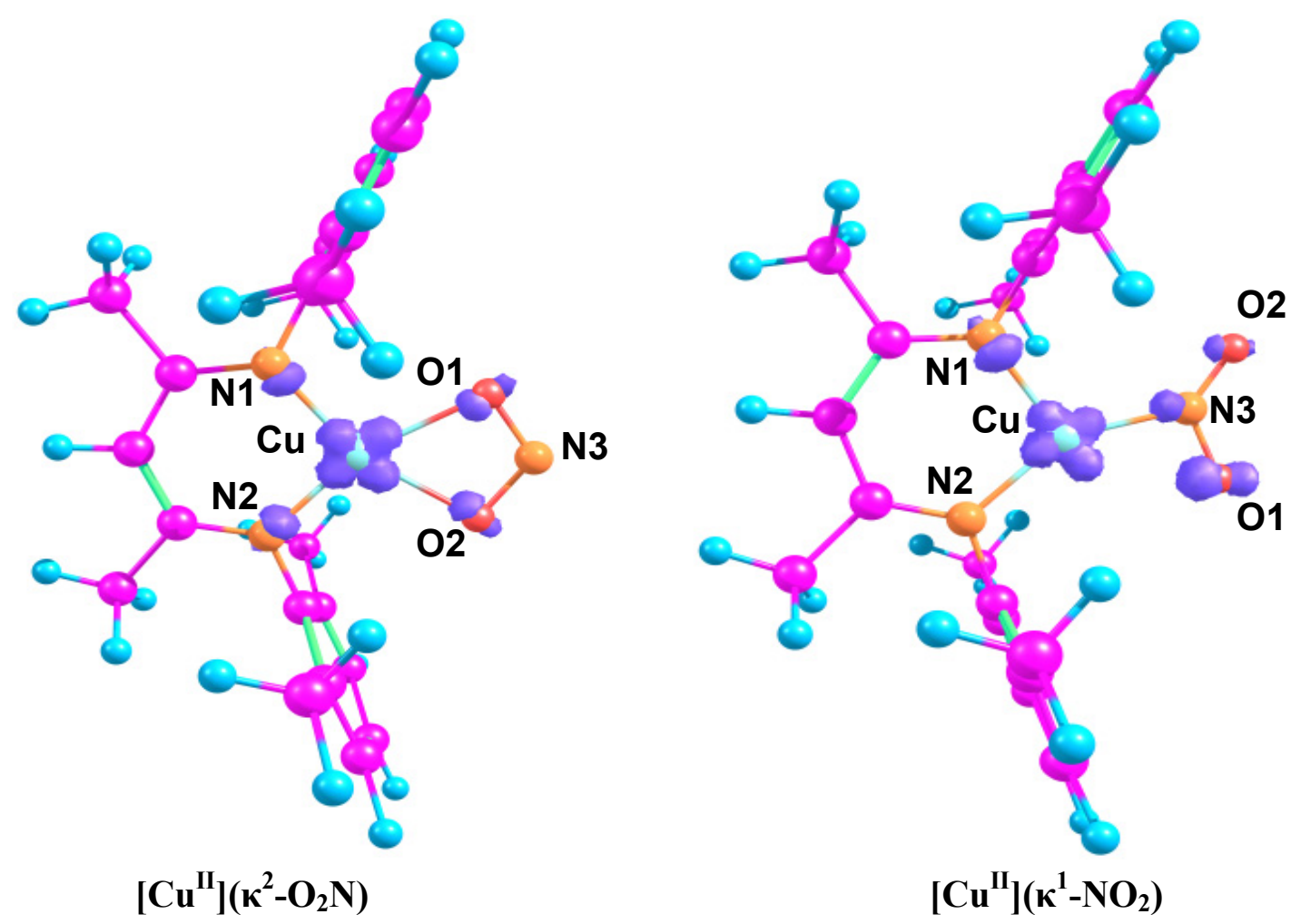

Figure S74. The calculated spin density plots of the $\kappa^{2}-\mathrm{O}$ and $\kappa^{1}-\mathrm{N}$ binding modes of copper(II) nitrite 4. Isosurface value $=0.02$. Spin densities $\left[\mathrm{Cu}^{\mathrm{II}}\right]\left(\kappa^{2}-\mathrm{O}_{2} \mathrm{~N}\right): \mathrm{Cu} 44 \%, \mathrm{O} 1$ $7 \%, \mathrm{~N} 30 \%, \mathrm{O} 27 \%$; [Cu $\left.\mathrm{Cu}^{\mathrm{II}}\right]\left(\kappa^{1}-\mathrm{NO}_{2}\right): \mathrm{Cu} 34 \%, \mathrm{O} 114 \%, \mathrm{~N} 311 \%, \mathrm{O} 25 \%$.
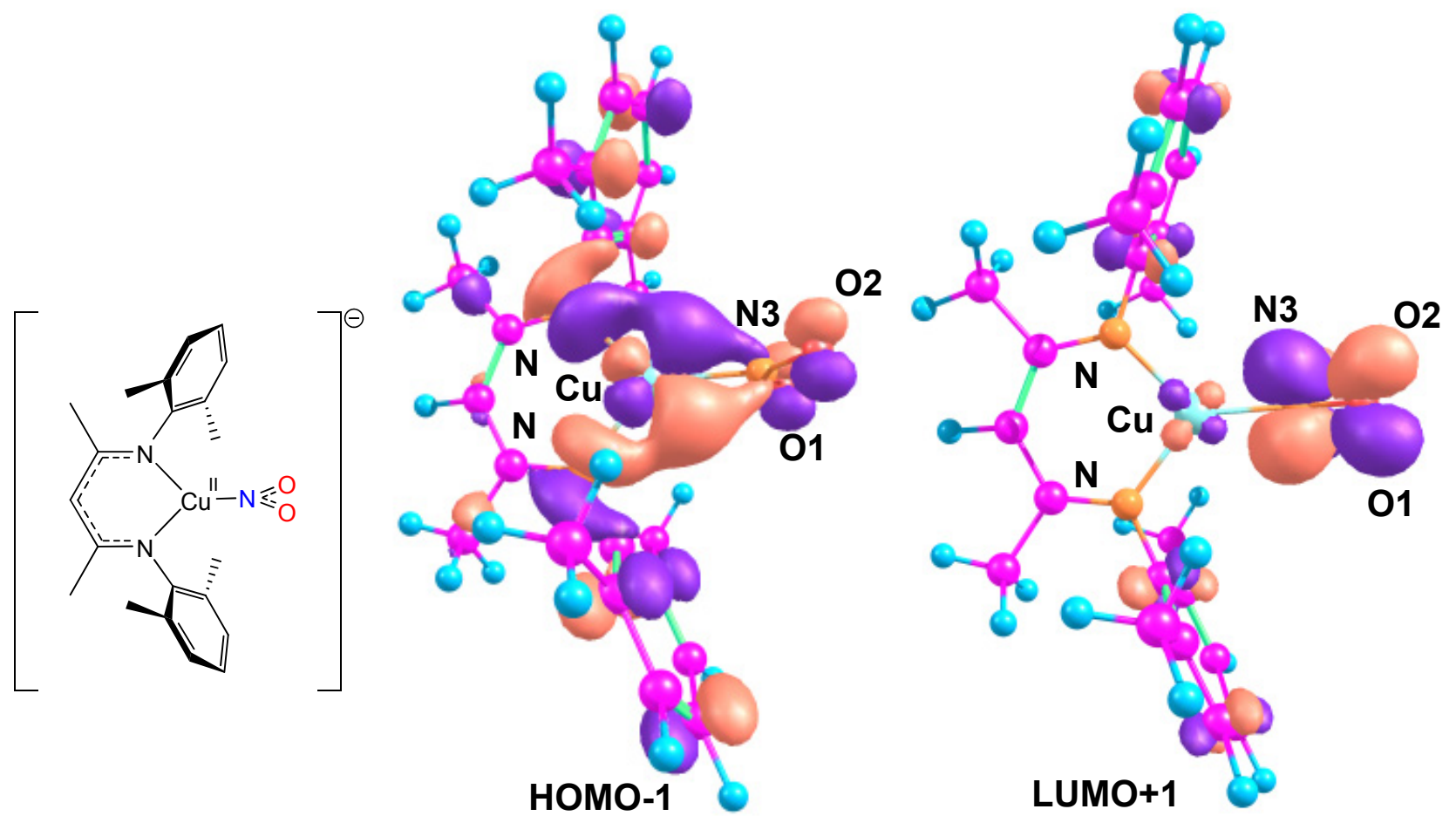

Figure S75. The second highest occupied molecular orbital (HOMO-1) and second lowest unoccupied molecular orbital (LUMO+1) of $\left\{\left[\mathrm{Cu}^{\mathrm{I}}\right]\left(\kappa^{1}-\mathrm{NO}_{2}\right)\right\}^{-}$indicating a $\pi$ backbonding interaction between the copper(I) center ] and the nitrite. Isosurface value $=0.03$ and 0.01 respectively. 


\section{References}

1. Kundu, S.; Kim, W. Y.; Bertke, J. A.; Warren, T. H. Copper(II) Activation of Nitrite: Nitrosation of Nucleophiles and Generation of NO by Thiols. J. Am. Chem. Soc. 2017, 139, 1045-1048.

2. Kundu, S.; Greene, C.; Williams, K. D.; Salvador, T. K.; Bertke, J. A.; Cundari, T. R.; Warren, T. H. Three-Coordinate Copper(II) Aryls: Key Intermediates in C-O Bond Formation. J. Am. Chem. Soc. 2017, 139, 9112-9115.

3. Badiei, Y. M.; Dinescu, A.; Dai, X.; Palomino, R. M.; Heinemann, F. W.; Cundari, T. R.; Warren, T. H. Copper-Nitrene Complexes in Catalytic C-H Amination. Angew. Chem. Int. Ed. 2008, 47, 9961-9964.

4. Melzer, M. M.; Mossin, S.; Cardenas, A. J. P.; Williams, K. D.; Zhang, S.; Meyer, K.; Warren, T. H. A Copper(II) Thiolate from Reductive Cleavage of an $S$-Nitrosothiol. Inorg. Chem. 2012, 51, 8658-8660.

5. (a) SHELXTL-PC, Vers. 5.10; 1998, Bruker-Analytical X-ray Services, Madison, WI;

(b) G. M. Sheldrick, SHELX-97, Universität Göttingen, Göttingen, Germany.

6. SADABS; G. M. Sheldrick, 1996, based on the method described in R. H. Blessing, Acta Crystallogr. Sect. A 1995, 51, 33-38.

7. Gaussian 16, Revision A.03, M. J. Frisch, G. W. Trucks, H. B. Schlegel, G. E. Scuseria, M. A. Robb, J. R. Cheeseman, G. Scalmani, V. Barone, G. A. Petersson, H. Nakatsuji, X. Li, M. Caricato, A. V. Marenich, J. Bloino, B. G. Janesko, R. Gomperts, B. Mennucci, H. P. Hratchian, J. V. Ortiz, A. F. Izmaylov, J. L. Sonnenberg, D. Williams-Young, F. Ding, F. Lipparini, F. Egidi, J. Goings, B. Peng, A. Petrone, T. Henderson, D. Ranasinghe, V. G. Zakrzewski, J. Gao, N. Rega, G. Zheng, W. Liang, M. Hada, M. Ehara, K. Toyota, R. Fukuda, J. Hasegawa, M. Ishida, T. Nakajima, Y. Honda, O. Kitao, H. Nakai, T. Vreven, K. Throssell, J. A. Montgomery, Jr., J. E. Peralta, F. Ogliaro, M. J. Bearpark, J. J. Heyd, E. N. Brothers, K. N. Kudin, V. N. Staroverov, T. A. Keith, R. Kobayashi, J. Normand, K. Raghavachari, A. P. Rendell, J. C. Burant, S. S. Iyengar, J. Tomasi, M. Cossi, J. M. Millam, M. Klene, C. Adamo, R. Cammi, J. W. Ochterski, R. L. Martin, K. Morokuma, O. Farkas, J. B. Foresman, and D. J. Fox, Gaussian, Inc., Wallingford CT, 2016.

8. (a) ChemCraft 1.8 [http://www.chemcraftprog.com], (b) Macrae, C. F.; Sovago, I.;

Cottrell, S. J.; Galek, P. T. A.; McCabe, P.; Pidcock, E.; Platings, M.; Shields, G. P.; Stevens, J. S.; Towler, M.; Wood P. A. Mercury 4.0: from visualization to analysis, design and Prediction. J. Appl. Cryst. 2020, 53, 226-235.

9. (a) Becke, A. D. Density-functional exchange-energy approximation with correct asymptotic behavior. Phys. Rev. A 1988, 38, 3098-3100. (b) Perdew, J. P. Density-functional approximation for the correlation energy of the inhomogeneous electron gas. Phys. Rev. B 1986, 33, 8822-8824. 
10. Hariharan, P. C.; Pople, J. A. The influence of polarization functions on molecular orbital hydrogenation energies. Theoret. Chimica Acta 1973, 28, 213-222.

11. Francl, M. M.; Petro, W. J.; Hehre, W. J.; Binkley, J. S.; Gordon, M. S.; DeFrees, D. J.; Pople, J. A. Self-consistent molecular orbital methods. XXIII. A polarization-type basis set for second-row elements. J. Chem. Phys. 1982, 77, 3654-3665.

12. Rassolov, V.; Pople, J. A.; Ratner, M.; Windus, T. L. 6-31G ${ }^{*}$ basis set for atoms K through Zn. J. Chem. Phys. 1998, 109, 1223-1229.

13. McLean, A. D.; Chandler, G. S. Contracted Gaussian basis sets for molecular calculations. I. Second row atoms, $\mathrm{Z}=11-18$. J. Chem. Phys. 1980, 72, 5639-5648.

14. Raghavachari, K.; Binkley, J. S.; Seeger, R.; Pople, J. A. Self-consistent molecular orbital methods. XX. A basis set for correlated wave functions. J. Chem. Phys. 1980, 72, 650-654.

15. Blaudeau, J.-P.; McGrath, M. P.; Curtiss, L. A.; Radom, L. Extension of Gaussian-2 (G2) theory to molecules containing third-row atoms K and Ca. J. Chem. Phys. 1997, 107, 50165021.

16. Wachters, A. J. H. Gaussian Basis Set for Molecular Wavefunctions Containing Third-Row Atoms. J. Chem. Phys. 1970, 52, 1033-1036.

17. Hay, P. J. Gaussian basis sets for molecular calculations. The representation of $3 \mathrm{~d}$ orbitals in Transition-metal atoms. J. Chem. Phys. 1977, 66, 4377-4384.

18. Raghavachari, K.; Trucks, G. W. Highly correlated systems: Excitation energies of first row transition metals Sc-Cu. J. Chem. Phys. 1989, 91, 1062-1065.

19. Binning Jr., R. C.; Curtiss, L. A. Compact contracted basis sets for third-row atoms: Ga-Kr. J. Comp. Chem. 1990, 11, 1206-1216.

20. McGrath, M. P.; Radom, L. Extension of Gaussian-1 (G1) theory to bromine-containing molecules. J. Chem. Phys. 1991, 94, 511-516.

21. Curtiss, L. A.; McGrath, M. P.; Blaudeau, J.-P.; Davis, N. E.; Binning Jr., R. C.; Radom, L. Extension of Gaussian-2 theory to molecules containing third-row atoms Ga-Kr. J. Chem. Phys. 1995, 103, 6104-6113.

22. Grimme, S.; Ehrlich, S.; Goerigk, L. Effect of the damping function in dispersion corrected density functional theory. J. Comp. Chem. 2011, 32, 1456-1465.

23. Marenich, A. V.; Cramer, C. J.; Truhlar, D. G. Universal Solvation Model Based on Solute Electron Density and on a Continuum Model of the Solvent Defined by the Bulk Dielectric Constant and Atomic Surface Tensions. J. Phys. Chem. B 2009, 113, 6378-6396. 